UNIVERSIDADE DE BRASÍLIA

INSTITUTO DE RELAÇÕES INTERNACIONAIS

PROGRAMA DE PÓS-GRADUAÇÃO EM RELAÇÕES INTERNACIONAIS

NATÁLIA BANDEIRA RAMOS COELHO

\begin{abstract}
EM BUSCA DE PRESTÍGIO INTERNACIONAL? A POLÍTICA EXTERNA BRASILEIRA PARA OBTENÇÃO DE ASSENTOS PERMANENTES NA LIGA DAS NAÇÕES E NA ONU (1921-1926; 1994-2010)
\end{abstract}




\section{EM BUSCA DE PRESTÍGIO INTERNACIONAL? A POLÍTICA EXTERNA BRASILEIRA PARA OBTENÇÃO DE ASSENTOS PERMANENTES NA LIGA DAS NAÇÕES E NA ONU (1921-1926; 1994-2010)}

Dissertação apresentada à Universidade de Brasília como requisito para obtenção do título de Mestre em Relações Internacionais na área de concentração História da Política Exterior do Brasil.

Orientador: Prof. Dr. José Flávio Sombra Saraiva. 


\section{EM BUSCA DE PRESTÍGIO INTERNACIONAL? A POLÍTICA EXTERNA BRASILEIRA PARA OBTENÇÃO DE ASSENTOS PERMANENTES NA LIGA DAS NAÇÕES E NA ONU (1921-1926; 1994-2010)}

Esta dissertação foi julgada adequada para a obtenção do título de Mestre em Relações Internacionais, na área de concentração História da Política Exterior do Brasil, pelo Instituto de Relações Internacionais da Universidade de Brasília, e aprovada em sua forma final pelo Orientador e pela Banca Examinadora.

Aprovada em: 10 de dezembro de 2014.

Orientador:

Prof. Dr. José Flávio Sombra Saraiva, UnB

Doutor em História pela Universidade de Birminghan, Grã-Bretanha

Banca Examinadora:

Prof. Dr. Antônio Carlos Moraes Lessa

Doutor em História das Relações Internacionais pela Universidade de Brasília, UnB

Prof. Dr. Virgílio Caixeta Arraes

Doutor em História pela Universidade de Brasília, UnB 
À minha mãe, cujo exemplo me mostrou perseverança e coragem. Ao meu pai, por ensinar-me os tesouros que se encontram nos livros. Ao meu amor, minha inesgotável inspiração, pelo apoio a cada passo do caminho. 


\section{AGRADECIMENTOS}

Tanto minha mãe, Lourdes Bandeira, quanto meu pai, Paulo Coelho, são professores da Universidade de Brasília. Seus exemplos influenciaram minha vida acadêmica e a escolha de seguir o mestrado. Agradeço à minha mãe, exemplo de competência e integridade, que sempre incentivou meus estudos, e ao meu pai, apaixonado pelo que faz e que, há gerações, encanta seus alunos. Aos demais membros da minha família, minha querida avó, meus irmãos, Felippe, Matheus, Christiane, Letícia, minhas tias, Leda, Lúcia, Lorena e meu tio Cézar agradeço o apoio e o carinho recebidos ao longo da minha vida.

Merece especial agradecimento meu orientador, o professor doutor José Flávio Sombra Saraiva. A generosidade com que me acolheu transcende qualquer imposição acadêmica e demonstra a nobreza de seu caráter. Sempre atencioso e gentil, deu-me espaço para desenvolver minhas percepções e nutriu em mim uma admiradora e amiga. Suas valiosas orientações, além de ajudar-me na elaboração desta dissertação, servir-me-ão por toda a vida.

Gostaria de agradecer aos meus professores do Instituto de Relações Internacionais da Universidade de Brasília, do mestrado e da graduação. Seus valiosos ensinamentos ajudaram minha formação como profissional, como brasileira e como ser humano atento às complexidades do mundo ao seu redor. Em especial, gostaria de mencionar os professores Pio Penna Filho, Cristina Inoue, Antonio Jorge Ramalho e Tânia Manzur.

Ao meu chefe, Luis Antônio Balduino Carneiro, do Departamento Financeiro e de Serviços do Itamaraty, agradeço a compreensão e o apoio durante a fase em que estive envolvida com as demandas acadêmicas. Aos colegas de trabalho e de mestrado, muitos dos quais se tornaram grandes amigos, como a Maria Helena Nottari e a Raquel Simões Barbosa, os debates interessantes e as trocas de experiências enriqueceram minha compreensão das relações internacionais, consequentemente, esta dissertação.

Agradeço, finalmente, ao Eugênio Garcia, por sua inestimável contribuição tanto no âmbito acadêmico quanto no pessoal. Dos incontáveis méritos deste mestrado, o fato de ter-nos aproximado é, para mim, o mais importante. Sua presença e seu apoio não apenas ajudaram a aperfeiçoar esta dissertação, como também tornaram minha vida mais feliz. Gratidão infinita a você e a todos de sua família, em especial à Mila, ao Benjamin, à Dilma e ao Clehir. 


\section{RESUMO}

A presente dissertação tem por objetivo analisar e comparar as iniciativas brasileiras em favor da conquista de assentos permanentes nos órgãos responsáveis pela paz e pela segurança mundiais da extinta Sociedade das Nações $(\mathrm{SdN})$ e da vigente Organização das Nações Unidas (ONU). Para realizar esta análise histórica, comparada, intraestatal e diacrônica, estudam-se os discursos do governo brasileiro que forneceram embasamento à campanha e os contextos interno, externo, regional e mundial dos dois momentos históricos em que estiveram vigentes as candidaturas. A análise comparada das políticas externas brasileiras, em relação às metas de obtenção de assentos permanentes no antigo Conselho Executivo da Liga das Nações e no atual Conselho de Segurança da ONU, visa desvendar quais fatores influenciaram, de forma preponderante, as aspirações brasileiras nos diferentes períodos e se houve continuidade dessa política apesar dos quase oitenta anos que separam os dois períodos históricos.

Palavras-chave: História da Política Externa do Brasil. Candidaturas brasileiras ao Conselho de Segurança da ONU e ao Conselho Executivo da Liga das Nações. 


\begin{abstract}
This dissertation aims to analyze and compare the Brazilian initiatives in favor of gaining permanent seats in the bodies responsible for international peace and security at the extinct League of Nations (LN) and at the current United Nations (UN). To accomplish this historical comparative analysis, the speeches of the Brazilian government that provided substance to the campaign were studied, as weel as the internal, external, regional and global contexts of the two historical moments in which the bids were attempted. The comparative analysis of Brazilian foreign policy in relation to the goals of obtaining permanent seats in the old Executive Council of the League of Nations and the current Security Council of the UN aims to uncover which factors mostly influenced Brazilian aspirations in different periods and if there was continuity of policy despite the eighty years separating the two historical periods.
\end{abstract}

Keywords: History of Brazilian Foreign Policy. Brazilian bid to the United Nations Security Council and to the Executive Council of the League of Nations. 


\section{SUMÁRIO}

Introdução

Capítulo 1 - A candidatura brasileira ao Conselho Executivo da Liga das Nações (19211926)

1.1 A participação brasileira na Conferência da Paz (1919)

1.2. O Brasil na Liga das Nações

1.3. A proposta chilena para que o Brasil fosse membro permanente 11

1.4. O governo de Artur Bernardes $\quad 13$

1.5. Os Acordos de Locarno 17

1.6. Apoios ao pleito brasileiro 19

1.7. A crise de março e o veto brasileiro 24

1.8. Os trabalhos da comissão e a saída do Brasil da Liga 28

1.9. O isolamento esplêndido e o possível retorno à Liga 34

1.10. Avaliação da política brasileira para a Liga 38

Capítulo 2 - A candidatura brasileira a um assento permanente no Conselho de Segurança da ONU (1994-2010)

2.1. O Brasil e a reforma do Conselho de Segurança da ONU 42

2.2. O início do governo de Fernando Henrique Cardoso 44

2.3. A reforma ganha impulso $\quad 47$

2.4. A crise e a ambição brasileira

2.5. O início do governo Lula 53

2.6. O momentum da reforma

2.7. Arrefecimento das negociações diante da irredutibilidade dos posicionamentos 61

2.8. Análise dos apoios recebidos 66

$\begin{array}{ll}\text { Capítulo } 3 \text { - Análise comparativa das candidaturas } & 77\end{array}$

3.1 A candidatura indireta do Brasil ao Conselho de Segurança em 1944-1945 77

3.2. Período de incubação

3.3. As políticas externas de Cardoso e de Lula $\quad 82$

3.4. Critérios e parâmetros da comparação $\quad 84$

3.5. Análise comparativa da candidatura empreendida por Cardoso e por Lula $\quad 85$

3.6. Análise comparativa das campanhas para a Liga e para a ONU 93

Conclusão

102

$\begin{array}{ll}\text { Referências } & 106\end{array}$ 


\section{INTRODUÇÃO}

O tema da reforma das Nações Unidas tem estado reiteradamente presente aos debates da comunidade acadêmica e da imprensa mundiais. Estudos dedicam-se a esmiuçar as variáveis da reforma e as origens, as causas, as motivações e as chances de sucesso da candidatura brasileira a um assento permanente no Conselho de Segurança. De forma análoga, a história da política do Brasil para a Liga das Nações foi objeto de trabalhos densos e consistentes realizados por internacionalistas e historiadores ${ }^{1}$. Inexiste, contudo, uma análise comparada ampla do pleito de outrora, para ocupar uma vaga permanente no Conselho da Liga, com o recente, para ascender à instância máxima do sistema onusiano. Há, apenas, estudos parciais que focalizam em aspectos específicos, mas não abrangem a totalidade dos fatores existentes em cada momento.

A recorrência, na política externa brasileira, da meta de inserir o país como membro permanente nos conselhos reservados às grandes potências mundiais provocou a indagação sobre quais teriam sido as motivações subjacentes às candidaturas brasileiras, as causas de seu fracasso no passado e as dificuldades encontradas no pleito mais recente. As especificidades inerentes às características do Brasil - que dispõe de território com dimensão continental, de crescente importância econômica, de relações pacíficas e diversificadas com a totalidade das nações conferem à demanda brasileira por maior preeminência na configuração do sistema internacional uma condicionalidade única. Analisar, comparativamente, o conjunto das condições que impulsionaram e influenciaram, outrora, essa meta da política externa brasileira, e as que o fazem atualmente, é a proposta deste trabalho.

O fato de, em momentos históricos inteiramente distintos, o Brasil ter desenvolvido a ambição de ocupar uma posição protagônica no contexto internacional, fundamentando-se em bases argumentativas similares, constituiria um indicador da persistência de certas crenças a respeito de quais deveriam ser o papel, o status e o pertencimento do Brasil no plano internacional (Silva, 1998). A recorrência das candidaturas corroboraria análises que se utilizam do conceito de "substrato normativo", a fim de explicar a continuidade da política externa

\footnotetext{
${ }^{1}$ Cf. Braga, 2008; Garcia, 2006, 2005; Baracuhy, 2005; Leuchars, 2001; Santos, 1995; Hilton, 1983; Almeida, 1938; Calógeras, 1930; Scelle, 1927.
} 
nacional para a consecução dos objetivos de ocupar espaços político-estratégicos de destaque no panorama mundial:

A "continuidade" da política externa brasileira seria, nessa visão, nada mais do que a construção de um conjunto razoavelmente permanente de normas sobre como o Brasil deve agir frente à ordem internacional. A esse conjunto dá-se o nome de "substrato normativo" (Vargas, 2008: p. 2).

Ao compreender os múltiplos aspectos das candidaturas brasileiras - a situação interna do Brasil nos diferentes momentos, as influências exercidas pelas conjunturas internacionais e regionais, as estratégias de condução dessa aspiração durante os diferentes mandatos presidenciais, os empecilhos a sua realização no passado e no período mais recente - a presente dissertação procura ampliar o entendimento de um dos principais objetivos da diplomacia brasileira. A análise histórica e comparativa dos pleitos permite identificar as causas principais e as motivações da aspiração nacional de desempenhar papel de destaque na arena internacional, perceptível já nas primeiras décadas do século XX.

Se a busca por prestígio é uma motivação demasiadamente genérica e insuficiente para justificar tais candidaturas (Vargas, 2008), é inegável que essa foi significativa força motriz do insistente pleito brasileiro, sobretudo na campanha feita na década de 1920. Conforme será elucidado ao longo do trabalho, não somente a meta de conquistar prestígio variou, mas também a definição de prestígio sofreu alterações ao longo das candidaturas. Percebeu-se, contudo, que, mesmo com distintas nuances e ênfases, o desejo de alcançar um status diferenciado na arena internacional representou um traço de continuidade da política externa brasileira.

O recorte temporal deste trabalho teve seu término em 2010, com o fim do governo de Luiz Inácio Lula da Silva, não contemplando o mandato da atual presidenta Dilma Rousseff, por ainda estar em curso e a sua história, em permanente mudança. Um olhar preliminar sobre a condução da campanha sob a gestão da presidenta poderia sugerir que as prioridades da governante são distintas das eleitas por seu antecessor, não obstante ambos sejam do mesmo partido e sigam diretrizes similares de política externa. As diferenças de tom e de estratégia utilizados podem ser notadas nas menções oficiais ao tema, como ilustrou a fala do ex-assessor internacional da presidente Dilma Roussef, Guilherme de Aguiar Patriota:

A vaga permanente segue sendo um de nossos pleitos prioritários, mas o assunto não é tratado no dia a dia, mas, sim, de forma subterrânea. Se você 
deixa como prioridade publicamente, vira objeto de chantagem e tem que fazer concessões constantes. ${ }^{2}$

No que tange às considerações metodológicas, nesta dissertação utilizou-se, prioritariamente, o raciocínio indutivo, característico dos métodos históricos, embasado na coleta de dados e na interpretação dos fatos, aliado, subsidiariamente, ao raciocínio dedutivo, típico de trabalhos teóricos em relações internacionais, para ser feitas inferências, generalizações e análises contrafactuais. Foi empregada, portanto, uma combinação do método histórico, com técnicas de pesquisa em Relações Internacionais e em Ciência Política, com o objetivo de superar limitações impostas pela separação rígida e ineficaz entre análises históricas e teóricas. Essa aspiração vai ao encontro da tendência defendida por Amado Cervo:

Aproximar o quadro conceitual que permita avançar a pesquisa teórica, sem aprofundar o divórcio com as bases empíricas e a pesquisa histórica, a seu turno, sem desperdiçar as luzes de novas categorias explicativas. (Cervo, 1994: p.10)

De acordo com definição de Janet B. Johnson \& H. T. Reynolds, variáveis são os elementos que influenciam, afetam ou causam o fenômeno que se deseja compreender. Destarte, foram analisadas as influências exercidas por diferentes elementos nas aspirações brasileiras de alçar-se a membro permanente dos conselhos historicamente restritos às grandes potências. A importância das diferentes variáveis no processo de decisão e de implantação das candidaturas brasileiras foi estudada por meio do exame e da comparação de informações sobre as condições econômicas, políticas e sociais, dos cenários internos e mundiais, aliados aos elementos encontrados nos discursos dos presidentes, dos chanceleres e dos representantes brasileiros na Liga das Nações e na ONU. Logrou-se identificar, assim, elementos, ou variáveis, que influenciaram as aspirações brasileiras nos momentos históricos analisados, como ocorreu essa influência e se houve manutenção da preponderância de uma variável ou se os pleitos nacionais sofreram influências decisivas distintas.

A análise empreendida foi intraestatal e diacrônica, pois abordou seu objeto em dois momentos históricos distintos. Ao combinar o caráter intranacional com o intertemporal, permitiu-se enumerar de forma mais evidente as principais influências sobre as aspirações. O 2 Disponível em: http://operamundi.uol.com.br/conteudo/noticias/30071/brasil +muda+estrategia + por + vaga + permanente + no + conselho + de+seguranca+da+onu.shtml. Acesso: 3/07/2014. 
feito de comparar-se a política externa do mesmo país, no caso a brasileira, permitiu considerar características nacionais como constantes: "comparability can be enhanced by focusing on intranation instead of internation comparisons. (...) The advantage of intra-unit comparison is that inter-unit differences can be held constant" (Lipjhart, 1971: p. 689).

Esta dissertação realizou-se mediante a combinação de fontes primárias e secundárias. $\mathrm{O}$ fato de existirem amplas e densas pesquisas sobre o tema possibilitou o aproveitamento das narrativas históricas realizadas por diversos autores. Fontes primárias foram consultadas, tendo em vista que podem dar margem a novas interpretações e indagações. Dessa forma, foram examinados os arquivos do Itamaraty, tanto o Arquivo Histórico do Rio de Janeiro, para o período anterior a 1959, quanto os da Coordenação-Geral de Documentação Diplomática (CDO), a Biblioteca Nacional, a Coleção de Afrânio de Melo Franco e a documentação onusiana disponível no acervo digital daquela organização.

A análise discursiva histórica desenvolvida teve por objetivo perceber como foram moldadas as candidaturas do país aos órgãos supremos, responsáveis pela paz e pela segurança mundiais. Dessarte, o enfoque da dissertação é similar ao de cientistas sociais "cujo interesse na linguagem é geralmente limitado a descobrir 'o que realmente aconteceu', ou qual é realmente a atitude de um individuo com respeito a X, Y ou Z" (Gill apud. Bauer \& Gaskell, 2002: p. 244). Não é o intento deste estudo realizar uma apreciação das alocuções em si mesmas, escapando, por conseguinte, do escopo proposto pela metodologia da análise do discurso do campo da linguística, que se interessa pelo conteúdo e pela organização dos textos por si sós (op. cit., p. 247).

Efetuou-se, assim, a análise comparativa qualitativa dos discursos dos governos de Epitácio Pessoa, Artur Bernardes, Fernando Henrique Cardoso e Luiz Inácio Lula da Silva, concomitantemente com o estudo dos principais acontecimentos dos anos referentes aos seus mandatos que influíram nas conduções da política externa brasileira e na agenda internacional de reforma dos Conselhos da Liga e da ONU. No que diz respeito estritamente ao plano discursivo, verificou-se a importância conferida à candidatura brasileira ao Conselho de Segurança baseando-se na frequência com que foi mencionada, nos argumentos utilizados e nas credenciais apresentadas pelos representantes brasileiros para o país ocupar tal papel de destaque no ordenamento internacional. 
Faz-se necessário ressaltar que cada alocução estava restrita por aglomerado único de circunstâncias que refletiam desafios, constrangimentos e oportunidades tanto internos quanto regionais e mundiais. Uma infinidade de fatores influenciou a escolha dos elementos a ser citados e priorizados pelos governantes, de modo que seus discursos refletiam não apenas suas ideologias e políticas, mas também a soma de elementos conjunturais e estruturais de determinado espaço e tempo histórico específicos. Pretendeu-se, portanto, recuperar o essencial desses contextos e integrá-los numa análise de como influenciaram as conduções das políticas externas brasileiras para as candidaturas nacionais. Almejou-se produzir um conhecimento abrangente que permita ampliar a compreensão do período estudado, instigar futuras pesquisas e, quiçá, auxiliar as previsões quanto às possibilidades de concretização da atual aspiração do Brasil.

Nesse sentido, a dissertação está organizada em três capítulos. O primeiro destina-se a avaliar a candidatura brasileira a um assento permanente no Conselho da Liga das Nações, no período de 1921 a 1926, abrangendo os governos de Epitácio Pessoa e de Artur Bernardes. O segundo examina a campanha a uma cadeira permanente no CSNU, no momento de 1994 a 2010, que compreendeu os mandatos de Fernando Henrique Cardoso e de Luiz Inácio Lula da Silva. O terceiro capítulo, por sua vez, contempla a comparação dos elementos das candidaturas explicitadas nos capítulos anteriores. A conclusão elenca os traços de ruptura e de continuidade da política externa brasileira em relação a este tema. 


\title{
CAPÍTULO 1
}

\section{A candidatura brasileira ao Conselho Executivo da Liga das Nações}

\begin{abstract}
Wilson was the originator of the vision of a universal world organization, the League of Nations, which would keep the peace through collective security rather then alliances.
\end{abstract}

\section{Kissinger $^{3}$}

A data de 16 de janeiro de 1920 ficará inscrita na História como a do nascimento do novo mundo. A decisão que tomardes hoje será tomada, com efeito, em nome de todos os Estados aderentes ao Pacto: será o primeiro decreto lavrado em comum, em nome de todas as nações livres que, pela primeira vez no mundo, estarão ligadas para substituir, ao reino da força, o império do direito.

Léon Bourgeois, inaugurando a primeira sessão do Conselho da Liga das Nações ${ }^{4}$

O término da Primeira Grande Guerra (1914-1918) marcou o fim do equilíbrio de poder advindo do Concerto Europeu, que remontava ao Congresso de Viena de 1815. Woodrow Wilson foi o principal idealizador do ordenamento orquestrado no pós-guerra. O presidente norte-americano via as causas da guerra sobretudo no sistema europeu de balança de poder e buscou implantar uma ordem baseada na segurança coletiva, assegurada pelo conjunto de nações amantes da paz. A opinião pública, segundo Wilson, seria a grande força moral que constrangeria potenciais países agressores a não realizar atos contrários à paz (Kissinger, 1994).

No início de 1918, um ano antes da Conferência de Paz, em Versalhes, o governo britânico criou uma comissão, chefiada por Lord Phillimore, responsável por elaborar um projeto para a futura Liga das Nações. Com base neste anteprojeto e com o auxílio do Coronel House, seu amigo e confidente, Woodrow Wilson fez uma versão pessoal, contendo treze ${ }^{5}$ artigos (Soares, 1927). Após a chegada do presidente norte-americano à Europa, para preparar as negociações de paz, a concepção da Liga ganhou contribuições importantes, como a do representante britânico Lord Robert Cecil, que apresentou a ideia de instituir um órgão restrito,

\footnotetext{
${ }^{3}$ Kissinger, 1994: p. 30.

${ }^{4}$ Franco, 1955: p. 1163.

${ }^{5}$ É curioso observar o papel deste número na história. Para o presidente norte-americano Woodrow Wilson, trazia sorte, sendo, inclusive, o número de letras em seu nome e o de sua proposta de projeto para a SdN (Soares, 1927: 52). Para Franklin Roosevelt, era considerado um número azarento, tendo levado o presidente a recusar propostas de aumento do Conselho para este número (Hilderbrand, 1990).
} 
capaz de tomar decisões rápidas, repousando sobre a força e a coesão das grandes potências ${ }^{6}$ (Scelles, 1927). Outra sugestão de Cecil foi a de tornar públicos os trabalhos da Conferência e todos os tratados e acordos entre as nações associadas à futura organização (Soares, 1927).

Ambas as sugestões foram ao encontro do pensamento de Wilson, sendo imediatamente aceitas e incorporadas à proposta do presidente norte-americano. Na primeira sessão da Conferência da Paz, realizada em janeiro de 1919, o objetivo de criar a Liga das Nações foi oficialmente informado às demais nações pelo presidente francês Raymond Poincaré. As discussões quanto ao projeto da vindoura instituição perduraram até 29 de abril, quando se aprovou o Pacto da Sociedade das Nações $(\mathrm{SdN})^{7}$, incorporado ao Tratado de Paz (Soares, 1927).

Surgiu, assim, a fórmula que sobreviveria à própria Liga e perduraria até o século XXI, contemplada na Carta das Nações Unidas: um órgão geral, a Assembleia, de escopo universal, aberto à participação de todos os Estados em bases igualitárias; e um órgão restrito, o Conselho, regido pelas pentarquias dos Estados vitoriosos das duas Grandes Guerras mundiais. Outra fórmula organizacional durável, nascida do Pacto da Liga, foi a da Corte Permanente de Justiça Internacional. A sugestão do jurista norte-americano Elliot Root introduziu a hipótese de soluções judiciais aos conflitos internacionais, os quais eram resolvidos, até então, de forma política, por meio de conciliação e arbitragem (Soares, 1927). Assim, a emergência da SdN, em 1919, como instituição responsável pelo gerenciamento internacional, conferiu caráter jurídico ao sistema em detrimento da natureza diplomática e política da ordem promovida pelo extinto Concerto Europeu (Lafer apud. Garcia, 2005).

Os acordos de Versalhes eram, contudo, menos eficazes que o sistema derivado de Viena. Segundo Adam Watson, isso ocorria por duas razões principais: primeiramente, pela falta de elasticidade advinda da rigidez do conceito de segurança coletiva, que havia substituído a prática maleável do equilíbrio de poder, regulador das relações intereuropeias durante o século XIX; em segundo lugar, pelo fato de a nova legitimidade proclamada pela ordem de Versalhes, a ser regida pela recém-criada Liga das Nações, não ter meios efetivos de ser posta em vigor, tendo em vista não ter logrado engajar a participação das quatro grandes potências de então - os EUA, o Japão, a URSS e a Alemanha.

\footnotetext{
${ }^{6}$ Quem, primeiro, ter-se-ia referido à criação de um Conselho foi o sul-africano general Smuts. Lord Cecil adotou a ideia e foi o responsável por apresentá-la ao presidente Wilson (Franco, 1955: p. 1169).

${ }^{7}$ Termo sinônimo de Liga das Nações. Ambos serão usados indistintamente.
} 
$O$ resultado foi uma dicotomia perturbadora entre o aparato complexo e formal de uma sociedade mundial de Estados coletivamente garantida, que existia somente como uma ideia, e a realidade de uma luta de poder e de política não administrada e desordenada (...). (Watson, 2004: p. 394)

Apesar de a Liga ter tido sua ação enfraquecida, por não incluir nações pujantes da época, a ausência de enforcement power, ou seja, de capacidade de executar decisões, foi considerada sua principal debilidade e uma das causas de seu fracasso em impedir a eclosão da Segunda Guerra. O pacto da Liga aferia ao Conselho apenas autoridade para recomendar ações armadas, mas não dispunha de meios para obrigar os Estados a engajar seus recursos nestas intervenções nem de forças militares próprias, o que ocorreu, sobretudo, pela recusa britânica de conferir à Liga esse atributo (Hilderbrand, 1990; Saraiva, 2008).

O grande mérito da Sociedade das Nações residiu no caráter inovador dessa iniciativa. A Liga foi a primeira tentativa de integrar os países em uma estrutura organizacional que extrapolava a cooperação em temas específicos, como era o caso das suas precursoras, a União Internacional dos Telégrafos, criada em 1865, e a União Postal Universal, de $1874^{8}$, que, atualmente, funcionam como agências especializadas da ONU. Tendo objetivos tão amplos quanto os de promover a cooperação internacional e o de manter a paz e a segurança mundiais ${ }^{9}$, a experiência da Liga foi fundamental para assentar as bases de um ordemanento mundial de institucionalidade mais duradoura, como o que viria a ser orquestrado pelas Nações Unidas.

\subsection{A participação brasileira na Conferência da Paz (1919)}

O Brasil foi o único país da América do Sul a participar da Primeira Guerra Mundial. Apesar de ter sido periférica e insignificante na consecução da vitória pelos aliados, a contribuição brasileira conferiu ao país um status diferenciado em relação aos seus vizinhos, na conformação mundial do pós-guerra (Barman, 2014). Além do Brasil, a nações sul-americanas signatárias do Tratado de Paz de 1919 e integrantes da SdN na condição de membros originários foram Bolívia, Equador, Peru e Uruguai. No ano seguinte, em 1920, a Argentina, o Chile, a Colômbia, o Paraguai e a Venezuela foram convidados para aderir ao pacto (Almeida, 1938).

\footnotetext{
${ }^{8}$ Disponível em: http://www.un.org/en/aboutun/history/index.shtml. Acesso em: 10/11/2013.

${ }^{9}$ Disponível em: http://www.un.org/en/aboutun/history/index.shtml. Acesso em: 10/11/2013.
} 
Por ter sido um dos países beligerantes, o Brasil fez jus a ser convidado para participar da Conferência da Paz, em Paris. A intenção da França era que o número de representantes nacionais de cada país partícipe à Conferência fosse aferido pela classificação das nações de acordo com as contribuições na guerra. Seguindo esta lógica, o Brasil teria direito a ser representado por apenas um delegado. Contudo, o presidente norte-americano Woodrow Wilson discordou dessa classificação e intercedeu a favor do Brasil:

Uma nação de 25 milhões de habitantes, um grande país de matériasprimas, o maior aliado dos EUA na guerra, não podia ser equiparado às pequenas potências. $O$ critério de classificação deveria ser o econômico, determinando o interesse real na paz. E, de acordo com esse critério, sustentou Wilson, o Brasil não podia ser considerado pequena potência, mas, pelo menos, potência intermediaria, com 3 representantes na Conferência. ${ }^{10}$

Ao final, prevaleceu o ponto de vista norte-americano, com a delegação enviada pelo Brasil contendo três membros. A comissão foi chefiada por Epitácio Pessoa, eleito presidente enquanto estava em Paris. O dispositivo previsto no artigo $1^{\circ}$ do regulamento da Conferência previa que apenas os países considerados potências com "interesses gerais" tinham livre acesso a todas as sessões e comissões. Os demais, as potências com "interesses limitados" (Calógeras apud. Garcia, 2006: p. 52), só podiam participar das discussões com as quais tivessem alguma relação direta. Após árdua negociação, o Brasil logrou conseguir que os países considerados potências menores pudessem participar das comissões da Conferência e não somente das referentes a temas específicos. Este fato foi relevante, pois possibilitou-lhe estar presente à comissão encarregada de decidir a estrutura da Liga das Nações, discutindo a formação da nova ordem internacional (Lafer apud Garcia, 2005).

\subsection{O Brasil na Liga das Nações}

O formato escolhido para a Sociedade das Nações, em grande medida replicado na ONU, combinou a representação igualitária dos países, fundamentada nos preceitos do Direito Internacional, com a concessão de um fórum exclusivo para as grandes potências, embasada na realidade da distribuição assimétrica de poder. Assim, o Conselho Executivo da $\mathrm{SdN}$ foi

\footnotetext{
${ }^{10}$ Artigo de Aníbal Pinheiro, em Paris, de 18 de abril de 1919. Biblioteca Nacional, microfilmes, jornal O Imparcial, RJ, PRESIDENTE-SPR 8(26).
} 
composto pelas potências vitoriosas da Primeira Guerra, que dispunham de cinco assentos permanentes, mais quatro membros rotativos. O Brasil, novamente pelo apoio norte-americano, foi escolhido como um dos quatro membros temporários integrantes da primeira formação do Conselho, junto com a Bélgica, a Grécia e a Espanha.

$\mathrm{O}$ artigo IV do pacto da Liga previa que os membros não permanentes do Conselho fossem designados livremente pela Assembleia quando assim the conviesse. Esse artigo foi objeto de emenda na $2^{\mathrm{a}}$ Assembleia (1921) e passou a estabelecer que a Assembleia fixasse regras por maioria de dois terços, relativas à eleição dos membros não permanentes, à duração de seus mandatos e às suas condições de reelegibilidade. No entanto, alguns países que ocupavam as cadeiras rotativas do Conselho não queriam ceder seus lugares e dificultavam a votação da emenda (Scelle, 1927). Como as decisões do Conselho eram baseadas na unanimidade, mesmo os membros temporários dispunham, na prática, de poder de veto.

A Espanha logrou impedir, assim, a aprovação dessa emenda até a $7^{\mathrm{a}}$ Assembleia, em 1926, quando o seu representante, Quiñones de Leon, finalmente transmitiu a ratificação espanhola da nova versão do artigo IV do Pacto (Scelle, 1927). A ausência de regras válidas que estabelecessem a rotatividade dos assentos e regulamentassem a duração dos mandatos e as possibilidades de reeleição dos membros não permanentes favoreceu, o Brasil, que conseguiu manter-se presente ao Conselho Executivo durante todo o período em que participou da Liga, por meio de reeleições sucessivas, até o anúncio de sua retirada em 1926 (Almeida, 1938).

Na primeira reunião formal do Conselho Executivo da Liga das Nações, em 16 de janeiro de 1920, o discurso do representante brasileiro, Gastão da Cunha, então embaixador do Brasil em Paris, inaugurou o argumento que viria a ser a pedra angular da candidatura brasileira ao Conselho: o de o país ser o representante da Américas (Garcia, 2006). Tendo em vista a ausência dos EUA da Sociedade das Nações, em virtude da não ratificação do Tratado de Versalhes pelo Congresso norte-americano, o Brasil tornou-se o único país do continente a sentar-se no Conselho. Dessa forma, quando ocorreu a primeira alocução do Brasil, mesmo antes de ter sido estabelecida a meta por um assento permanente, Gastão da Cunha alegou ter recebido "um mandato implícito", autorizando-o a ser o "porta voz da consciência pan-americana"11

\footnotetext{
${ }^{11}$ Cunha a Marques, telegrama, Paris, 17/01/1920. AHI, 227/3/6.
} 


\subsection{A proposta chilena para que o Brasil fosse membro permanente}

$\mathrm{Na} 2^{\mathrm{a}}$ Assembleia (1921) da SdN, o representante chileno, Agustin Edwards, apresentou a proposta de ampliar os assentos do Conselho que previa a criação de duas novas cadeiras permanentes, as quais deveriam pertencer ao Brasil e à Espanha, "afin de voir représentés au Conseil les divers groupes politiques présents à la Société et, plus spécialement, l'Amérique latine" (Santos, 1995: p. 170). A proposição do Chile partia do pressuposto de que, diante da ausência de regras que estabelecessem o roulement dos assentos temporários, havia forte tendência a que Brasil e Espanha fossem indefinidamente reeleitos para seus respectivos assentos. Dessarte, Edwards tinha a intenção de torná-los membros permanentes para suas vagas rotatórias no Conselho serem ocupadas por outros Estados americanos, quiçá o próprio Chile. Não havia, portanto, na proposição chilena, a intenção de atestar reconhecimento das credenciais ou dos direitos do Brasil de ascender a um posto permanente. O que havia era uma tentativa encoberta do Chile de conseguir uma cadeira temporária (Soares, 1927).

Em ofício a Azevedo Marques, o ministro das Relações Exteriores, Gastão da Cunha informou ao governo a proposta chilena e afirmou não ter tido, no assunto, iniciativa alguma: "a proposta Edwards foi para mim uma surpresa. Levada a ideia ao Conselho, era meu dever defendê-la, mas o fiz alargando a ideia para abranger o nosso continente e falar, não pelo Brasil, mas pela América Latina" ${ }^{12}$. O embaixador brasileiro argumentou em defesa da proposta do Chile, por meio de critérios populacionais e econômicos: "as nações americanas que se mantêm fiéis à Liga das Nações contam cerca de 90 milhões de habitantes"; "sob o ponto de vista econômico, o continente europeu não está em posição muito superior ao americano"13. $\mathrm{O}$ histórico pacifista do continente americano também foi mencionado por da Cunha como critério justificador de maior participação das nações americanas: "A SdN é uma instituição internacional de paz e não é justo que, na sua direção, predomine, pelo número de representantes, exatamente, o continente menos pacífico"1 ${ }^{14}$.

A sugestão de Edwards foi rejeitada por cinco votos contrários. Um dos opositores, o representante da Grã-Bretanha, Arthur James Balfour, expôs uma contraproposta que previa a

\footnotetext{
${ }^{12}$ Cunha a Marques, ofício, Paris, 16/10/1921, AHI 274/2/1.

${ }^{13}$ Cunha a Epitácio, 03/10/1921, Genebra. AHI, Liga das Nações, Delegação do Brasil, ofícios recebidos, 1920$1921,274 / 2 / 1$.

${ }^{14}$ Cunha a Epitácio, 03/10/1921, Genebra. AHI, Liga das Nações, Delegação do Brasil, ofícios recebidos, 19201921, 274/2/1.
} 
criação de apenas um assento permanente destinado à Espanha. O embaixador brasileiro consultou o governo e recebeu instruções do presidente Epitácio Pessoa para não aceitar a proposição de Balfour, tendo em vista que "admitir a Espanha e repelir o Brasil, propostos simultaneamente, seria uma desconsideração com o país e não devemos, nem ativa, nem omissivamente, concorrer para tal decisão" ${ }^{15}$. Gastão da Cunha foi o único voto contrário à proposição britânica, o que, considerando a necessária unanimidade para aprovar as decisões do Conselho, representou um veto à Espanha. Esta foi a primeira ocasião em que o Brasil usou o recurso, e, apesar de o veto não ter provocado abalo nas relações entre os dois países, foi um prenúncio da crise que ocorreria cinco anos depois (Santos, 1995).

Na $3^{\text {a }}$ Assembleia (1922), foi aprovada a criação de dois novos assentos temporários do Conselho, que passou de quatro para seis cadeiras, sendo a Suécia e o Chile os novos integrantes. Nesta plenária, foram feitas recomendações no sentido de que os mandatos dos membros temporários do Conselho fossem restritos a três anos e de que os Estados levassem em conta nas eleições "des divisions géographiques, des familles ethniques d'États, des traditions religieuses, des divers types de civilisations, des sources principales de richesse des différents peuples" como princípios orientadores dos votos (Scelle, 1927: p. 17-18).

Diante do quadro restrito de condicionalidades para a reeleição dos membros não permanentes e da atmosfera de competição acirrada entre as potências menores para ocupar tais assentos, o novo representante do Brasil no Conselho, Domício da Gama, então embaixador em Londres e substituto de Gastão da Cunha na $3^{\mathrm{a}}$ Assembleia, recomendou ao governo trabalhar diplomaticamente, com o propósito de obter um assento permanente ${ }^{16}$. Nota-se, portanto, que a origem da candidatura brasileira a membro permanente surgiu como resposta às dificuldades encontradas em manter o assento temporário do Brasil no Conselho, percebidas em 1922, sem haver relação direta com questões de política interna.

A despeito das observações de Domício da Gama, durante a administração do presidente Epitácio Pessoa não foi estabelecida uma política que visasse à consecução de uma cadeira permanente no Conselho para o Brasil (Santos, 1995). Apenas na gestão de seu sucessor, Artur

\footnotetext{
${ }^{15}$ Epitácio a Cunha, 30/09/1921, urgente, RJ. AHI, Liga das Nações, Delegação do Brasil, ofícios recebidos, 1920$1921,274 / 2 / 1$.

${ }^{16}$ Gama a Pessoa, carta, Paris, 14/10/1922. AHI 274/2/1A. Santos, 1995: p. 173; Leuchars, 2001: p. 179; Garcia, 2006: p. 357-359.
} 
Bernardes, a candidatura do Brasil foi elaborada de forma consistente, tendo sido, inclusive, elevada à posição de principal meta da diplomacia nacional. A comparação entre as políticas externas dos dois presidentes demonstrou que, enquanto Pessoa desenvolveu uma política de "baixo perfil", satisfeito com a posição de "sócio menor na aliança dos vencedores" (Garcia, 2006: p. 359), Bernardes buscou a ascensão do status internacional do Brasil ao patamar simbólico de grande potência, a despeito das deficiências do país naquele quadrante da República Velha.

\subsection{O governo de Artur Bernardes}

Após agitada e conturbada campanha eleitoral, que trouxe à tona as tensões entre as elites regionais, Artur Bernardes assumiu a Presidência da República em 15 de novembro de 1922. O país atravessava momento de grave crise econômico-financeira e de instabilidade social. O novo governo instalou-se sob a vigência do estado de sítio decretado por Epitácio Pessoa, em julho daquele ano. Durante a gestão de Bernardes, novas insurreições despontaram, alastrando o quadro de restrição das liberdades civis por diversas regiões do país e fazendo que, durante 42 meses, a maior parte do território nacional estivesse sob estado de sítio (Santos, 1995).

Bernardes era conhecido pelo temperamento autoritário, ambicioso e, principalmente, obstinado: "o que se propunha a fazer, realizar, não havia obstáculo que o impedisse. Ia até o fim" (Monteiro, 1984: p. 55). O presidente chamou o jornalista Felix Pacheco para chefiar o Ministério das Relações Exteriores. O proprietário do Jornal do Comércio é retratado de forma predominantemente negativa, com descrições depreciativas de sua habilidade como chanceler: "não tinha nenhuma experiência diplomática e possuía uma visão muito limitada dos acontecimentos internacionais, interpretando-os sempre a partir do ponto de vista da política interior" (Santos, 1995: p. 97); "era um jornalista e polemista. Nunca um diplomata ou estadista. Não foi dos menores erros de Bernardes o haver-lhe confiado, por quatro anos, o Itamaraty" (Franco, 1955: p. 1263).

Tanto Bernardes quanto Pacheco tinham uma percepção limitada do jogo diplomático. Exerceram, contudo, o comando da política exterior brasileira de forma centralizadora, com mãos de ferro. No caso da Liga, as decisões advindas do Rio de Janeiro foram ponderadas pelas intervenções de Afrânio de Melo Franco, nomeado chefe da delegação brasileira em Genebra. A 
combinação das concepções de mundo desses dirigentes forneceu elementos importantes para a compreensão da atitude irredutível do Brasil na busca por uma vaga permanente no Conselho.

Em 13 de março de 1924, seria criada a Delegação Permanente do Brasil junto à SdN. Ao contrário do que é afirmado, o Brasil não foi o primeiro a ter uma representação permanente: "en 1924 plus d'une vingtaine de pays membres de la SdN ont deja établi une représentation permanente à Genève" (Soares, 1995: p. 108), entre os quais se encontravam três latinoamericanos: a Bolívia, o Chile e o Peru. O que o Brasil fez de inédito e singular foi designar um embaixador para chefiar a delegação, conferindo-a, dessa forma, o status equivalente ao de uma embaixada. A equipe era composta de um delegado adjunto, dois secretários e cinco assessores, além do embaixador (Franco, 1955). A grande importância atribuída pelo governo brasileiro à delegação permanente decorria de ter por função não apenas acompanhar as atividades da Liga, mas também promover e coordenar as ações em prol da candidatura do Brasil ao assento permanente no Conselho.

Quatro meses depois, Afrânio de Melo Franco chegou à Europa, para assumir a chefia da delegação permanente. Era amigo e conterrâneo do presidente Bernardes, e sua ampla experiência em assuntos internacionais incluía ter sido delegado do Brasil na $1^{\mathrm{a}}$ Conferência da Organização Internacional do Trabalho (OIT) e chefe da delegação à $5^{\mathrm{a}}$ Conferência PanAmericana, no Chile, em março de 1923. A experiência de Melo Franco no congresso continental serviu como excelente preparação para a missão em Genebra, para onde partiu apenas algumas semanas depois de seu regresso ao Brasil (Hilton, 1986).

Melo Franco chegou a Genebra com instruções para angariar apoio às candidaturas do Brasil e da Espanha a membros permanentes. O novo representante brasileiro, escolhido para chefiar a delegação na $4^{\text {a }}$ Assembleia, em setembro de 1923, defendeu o pleito do governo brasileiro de ascender permanentemente ao Conselho, alegando que "tant par sa population, que par son commerce international, l'Amérique devrait déjà avoir un siège permanent dans le Conseil"17. Melo Franco utilizou-se, assim, de argumentos similares aos empregados por seu antecessor, Gastão da Cunha, ao defender a necessidade de prover o continente de um representante no Conselho com base na importância populacional e econômica das Américas. O

\footnotetext{
${ }^{17}$ Melo Franco a Robert Cecil, Léon de Bourgeois e Branting, carta, Genebra, 20/09/1923. AHI, Liga das Nações, Delegação do Brasil, ofícios recebidos, 1922-1923, 274/2/1A.
} 
embaixador apresentou as credenciais do Brasil para representar o continente:

La population et le territoire sont supérieurs à ceux de tous les autres latino-américains réunis, membres de la Ligue. (...)

Le Brésil occupe la 7ème place dans la liste de ceux qui contribuent de la façon la plus importante à le budget de la Société des Nations ${ }^{18}$.

A proposta do representante brasileiro, encaminhada em memorando a todos os Estados representados no Conselho, previa que o Brasil ocupasse, temporariamente, o assento destinado aos EUA:

Quanto a nós, temos um argumento simples e que parece ser o principal em favor da nossa causa: não pretendemos aumentar o número de membros do Conselho, nem, portanto, emendar o Pacto. Temos por certo que o pacto reservou um lugar para a América, - lugar que reconhecemos pertencer de júri próprio aos Estados Unidos, que são, na pessoa de Wilson, os criadores do mesmo Pacto -, mas lugar que entendemos dever ser preenchido por nós, enquanto durar a ausência daquele país. ${ }^{19}$

Dessa forma, o país buscava contornar a intransigente resolução de alguns membros do Conselho, em especial Robert Cecil, representante da Grã-Bretanha, de impedir quaisquer ampliações nos assentos permanentes. A proposta brasileira, previa que a Espanha ocupasse a vaga destinada à Alemanha até que este país entrasse no órgão. A nação hispânica, contudo, rejeitou a sugestão, conforme relatou Melo Franco em telegrama a Pacheco: "Conversei com o embaixador Quiñones de León (...) mas me declarou peremptoriamente que a Espanha não poderia aceitar a eleição de membro permanente para guardar lugar para a Alemanha"20.

Faltando poucos meses para a $5^{\text {a }}$ Assembleia, o diplomata Raul Fernandes foi designado para conduzir uma missão especial com o obejtivo de obter o apoio dos líderes europeus ao pleito brasileiro. A missão itinerante estabeleceu contatos com os governos da Grã-Bretanha, dos Países Baixos, da Bélgica, da França, da Suécia e da Tchecoeslováquia, expondo os argumentos que embasavam a candidatura do Brasil ao assento permanente e coletando apoios (Garcia, 2006; Rodrigues, 1995; Melo Franco, 1955), porém mostrou-se infrutífera, tendo em vista que "os dignitários dos países visitados não pretendem comprometer-se em uma delicada questão e não consideram necessário desencorajar o Brasil e muito menos indicar um apoio real à nossa

\footnotetext{
${ }^{18}$ Melo Franco a Robert Cecil, Léon de Bourgeois e Branting, carta, Genebra, 20/09/1923. AHI, Liga das Nações, Delegação do Brasil, ofícios recebidos, 1922-1923, 274/2/1A.

${ }^{19}$ Melo Franco a Pacheco, confidencial, Genebra, 28/08/1924. AHI, SdN, DPB, ofícios recebidos, 1924, 274/2/5.

${ }^{20}$ Melo Franco a Pacheco, telegrama, 21/09/1923. AHI, Liga das Nações, telegramas recebidos, 1920-1924, $274 / 2 / 3$.
} 
pretensão" (Rodrigues, 1995: p. 307).

Além da missão itinerante, Pacheco buscou outras estratégias na consecução da vaga no Conselho. A delegação brasileira foi instada a empregar esforços pessoais ininterruptos junto a todas as delegações permanentes em Genebra. O chanceler e o presidente também solicitavam ao representante brasileiro manter contato telegráfico diário com as embaixadas europeias "para promover o que for conveniente no momento justo" ${ }^{21}$. Melo Franco insistia, contudo, que o governo brasileiro trabalhasse pela eleição do Brasil, por meio de negociações diretas entre o Itamaraty e as chancelarias dos países membros da Liga, pois os delegados dos países que se encontravam em Genebra não "se acham munidos de instruções para resolver assunto tão complexo e que exige madura reflexão dos próprios governos dos Estados" (Melo Franco apud. Franco, 1955: p. 1234).

O Itamaraty ignorou as recomendações de seu emissário e pouco fez no sentido indicado. Sua omissão foi mais sensível no que tange às chancelarias latino-americanas, cuja falta de solidariedade à reivindicação brasileira contribuiu para o fracasso da empreitada. O Ministério dos Negócios Estrangeiros deixava recair, portanto, o peso da condução da candidatura nos ombros de Melo Franco, que batalhava de maneira sobre-humana em Genebra ${ }^{22}$. O representante do Brasil defendia que a candidatura fosse abordada em conversas nos bastidores, pois "o trabalho para o nosso êxito não pode ser feito no tumulto da atividade da Assembleia, mas, sim, no intervalo das sessões e por negociações de governo a governo" ${ }^{23}$. Infere-se, então, a persistência de práticas tradicionais em que as reuniões públicas serviam apenas para formalizar o que havia sido discutido e decidido previamente.

Um evento importante coincidiu com a reunião da $5^{\mathrm{a}}$ Assembleia (1924). Em 29 de setembro, o governo da Alemanha enviou um aide-mémoire a todos os países representados no Conselho, indagando suas opiniões sobre a entrada do Estado alemão (Santos, 1995: p. 181). O memorando reclamava a aplicação do "princípio da igualdade", o que, para a República de Veimar, significava receber, no Conselho, status idêntico ao das outras grandes potências, ou

\footnotetext{
${ }^{21}$ Pacheco a Melo Franco, telegrama, 20/09/1923. BN, Seção de Manuscritos, Coleção Melo Franco, SdN, 1923, pasta 638 . AHI 274/2/4.

${ }^{22}$ Melo Franco relatou em carta a seu filho sobre o período da sessão extraordinária da Assembleia, em março de 1926: "vivi pela energia nervosa, sem comer, sem dormir, sem conseguir isolar-me, ao menos para fechar os olhos e refletir" (Melo Franco apud. Hilton, 1986: p. 21).

${ }^{23}$ Melo Franco, relatório. AHI, DPB junto à SdN, documentação interna, Relatórios do Embaixador Afrânio de Melo Franco, 1924-1925, 322/1/34.
} 
seja, o de membro permanente (Scelle, 1927: p. 22). Todos os países consultados expressaram consentimento com a entrada da nação germânica, porém o Brasil respondeu de forma vaga e imprecisa, dando indícios do que seria sua atitude no futuro:

As questões concretizadas nos desejos expressos pela Alemanha pertencem à natureza das que não devem ser tratadas de Governo a Governo, mas, de preferência, expostas e discutidas em conjunto pelos membros da Sociedade e no seio desta, a fim de serem melhor conhecidos os vários aspectos das ditas questões e os pontos de vista dos outros associados.

(...) o Brasil nenhuma objeção tem a opôr, em tese, à entrada da Alemanha como membro da Sociedade das Nações, antes deseja que essa entrada se verifique. Também, em princípio, o Brasil não se opõe a que o novo membro obtenha um lugar permanente no Conselho. Essas questões e as outras a que se refere o Memorandum da Chancelaria alemã serão encaradas pelo Brasil com sereno espírito e justa ponderação quando formos chamados a tratar do assunto no debate do mesmo pela Assembleia da Sociedade ${ }^{24}$.

\subsection{Os Acordos de Locarno}

Em 16 de outubro de 1925, foram concluídas, na cidade suíça de Locarno, as negociações sobre as fronteiras europeias estabelecidas em Versalhes e a proscrição da guerra entre os principais líderes europeus: Stresemann, representando a Alemanha; Vandervelde, a Bélgica; Briand, a França; Chamberlain, a Grã-Bretanha; Mussolini, a Itália; Skrzynski, a Polônia e Bénès, a Tchecoeslováquia (Franco, 1955). Os acordos de Locarno tiveram tamanha importância como marco da aproximação franco-alemã da política de segurança europeia que o prêmio Nobel de 1926 foi conferido a Chamberlain, Briand e Stresemann, "para recompensá-los dos serviços que prestaram à humanidade" (Soares, 1927: p. 122).

Conquanto tenha sido decidido, somente pelas grandes potências, fora do âmbito da Liga das Nações, o Pacto de Locarno vinculava-se ao sistema da Liga e previa a entrada da Alemanha no Conselho. Para tanto, o acordo estipulou que todos os Estados membros da SdN deveriam colaborar "leal e eficazmente para que o pacto locarniano fosse respeitado" (Scelle, 1927: p. 24). Dessarte, a entrada da Alemanha foi apresentada aos demais Estados da comunidade internacional como um fait accompli, demostrando que, na prática, as decisões das grandes

\footnotetext{
${ }^{24}$ Despacho, Pacheco a Melo Franco, Rio de Janeiro, 01/12/1924. Cópia do texto definitivo enviado à Legação Alemã. AHI, Liga das Nações, Delegação Permanente, despachos, 1924-1925, 274/2/11.
} 
potências se impunham às da Liga. No entanto, não foram capazes de prever, naquele momento, a crise que se seguiria em breve:

Ni Allemagne ne demanda à ses partenaires de préciser que son entrée au Conseil serait exclusive de tout modification dans la composition de cet organe; ni les alliés ne firent remarquer à l'Allemagne que sa prise de possession du siège que lui était réservé pouvait susciter d'autres candidatures dont certaines, au surplus, s'étaient déjà produites" (Scelle, 1927: p. 25)

Em 8 de fevereiro de 1926, o governo alemão solicitou, formalmente, sua entrada na Liga. Uma sessão extraordinária da Assembleia, a primeira na história da instituição, foi convocada para o início de março, para pronunciar-se, o quanto antes, sobre o caso. Dias antes, contudo, em meados de janeiro, o governo de Varsóvia havia anunciado a candidatura de seu país a um posto permanente do Conselho. O pleito polonês de entrar concomitantemente com a Alemanha gerou ferrenha oposição de Hans Luther, e levou o chanceler alemão a fazer uma declaração pública de que a Alemanha exigia entrar sozinha no Conselho, mantendo-se a composição do órgão igual à de quando foram firmados os acordos de Locarno (Santos, 1995).

A França queria aproveitar a revisão do conselho para colocar a Polônia como membro permanente, o que serviria para contrabalançar a entrada da nação teutônica no Conselho. A insistência francesa em apoiar justamente a Polônia, ciente de que o país era alvo de grande antipatia alemã, por pendências lindeiras e minorias populacionais germânicas no território polonês $^{25}$, levantou suspeitas de que a França nutria esperanças de que a Alemanha terminasse por não entrar no Conselho (Leuchars, 2001).

O Brasil manifestou indignação em relação à declaração alemã de que deveria entrar sozinha no Conselho. Felix Pacheco considerou essa atitude injustificável, desleal e consultou Melo Franco sobre a possibilidade de usar o veto contra a nação alemã. O embaixador brasileiro em Genebra manifestou-se, todavia, contrário à utilização desse recurso nas comunicações mantidas com o chanceler, conforme demonstram trechos dos seus telegramas datados de fevereiro de 1926:

Não creio possível exercer o direito de veto contra a Alemanha (...) isso teria por efeito a queda do Tratado de Locarno.

\footnotetext{
25 "De resto, essa incompatibilidade germano-polonesa seria uma das causas da ascensão nazista e da Segunda Guerra Mundial" (Franco, 1955: p. 1238).
} 
Nós nos exporíamos a uma situação muito desagradável e à condenação pela opinião universal, se assumíssemos esse odioso papel. ${ }^{26}$

Não obstante a advertência alemã de que sua entrada no Conselho deveria dar-se com exclusividade, o Brasil viu, na revisão do Pacto por ocasião da sessão extraordinária, uma oportunidade de obter o tão almejado assento permanente. Assim, Pacheco intensificou a candidatura do Brasil, divulgando-a em entrevista concedida à United Press International (Garcia, 2006). Similarmente, a China e a Espanha aproveitaram a ocasião para renovar suas candidaturas, trazendo elementos complicadores adicionais à Assembleia extraordinária que culminaram na crise de março de 1926.

\subsection{Apoios ao pleito brasileiro}

O continente americano foi entusiasta do estabelecimento da Liga, tendo dezesseis nações latinas associadas à organização desde sua fundação, como membros originários ${ }^{27}$. Nas Assembleias da $\mathrm{SdN}$, as posições dos países latino-americanos eram guiadas por seus governos nas capitais, que concediam pouca margem de manobra aos delegados em Genebra. No decorrer dos trabalhos da Liga, começaram a ser formadas reuniões de representantes dos países latinos para chegar a posições comuns em temas de interesses convergentes. A concertação política entre esses países centrava-se em negociações sobre questões de representatividade na Sociedade (Santos, 1995), incluindo-se, portanto, o tema suscitado pelo pleito brasileiro de ter um assento no Conselho para supostamente representar a região.

A maior parte dos países hispano-americanos nunca validou a atitude brasileira de arrogar-se o direito às suas representações conquanto a tese da representação continental tenha sido a principal fundamentação argumentativa da candidatura brasileira a um assento no Conselho. Conforme atestou Macedo Soares, "nenhum país da América, nem mesmo o Chile pela voz do Sr. Edwards, reclamou que se aplicasse ao Brasil o critério de 'grande potência' para que tivesse direito a uma cadeira permanente no Conselho da Sociedade das Nações" (Soares, 1927: p. 168).

\footnotetext{
${ }^{26}$ Melo Franco a Pacheco, telegramas, confidencial. Fev de 1926. AHI 274/3/1.

${ }^{27}$ Dez delas assinando diretamente o Tratado de Versalhes e seis sendo convidadas a aderir a pacto nos dois meses seguintes a sua entrada em vigor (Santos, 1995: p. 209).
} 
Em diversas reuniões realizadas paralelamente às atividades da Liga, como a que ocorreu em 23 de setembro de 1925, o posicionamento majoritário dos países latinos defendia a introdução de um sistema de rodízio entre todas as nações do continente, em vez da concessão de assentos permanentes a um ou outro país, como advogava o Brasil (Leuchars, 2001). Isso trazia à tona a dicotomia existente entre a posição brasileira e a do restante da América Latina e enfraquecia o posicionamento do Brasil diante das potências europeias (Rodrigues, 1995).

Em relação à postura adotada pela Grã-Bretanha, ao longo de toda a campanha brasileira, esta figurou como o principal estorvo entre o Brasil e o almejado assento permanente. O que o governo brasileiro, na época, desconhecia era que o gabinete britânico chegou a discutir o assunto e, ao menos parte dele, foi favorável ao seu pleito. O próprio representante britânico no Conselho, Robert Cecil, acreditava que todas as partes do mundo tinham direito a uma representação permanente no Conselho. Igualmente, o Secretário-Geral da Liga, o britânico Sir Eric Drummond, sugeriu a Austen Chamberlain, Ministro de Negócios Estrangeiros da GrãBretanha na época, que um assento permanente fosse criado para ser compartilhado entre Brasil, Argentina e Chile (Leuchars, 1983).

Os acordos de Locarno eram, entretanto, demasiadamente importantes para a reconstrução da paz europeia, e a Grã-Bretanha não os iria colocar em risco nem seria coagida por ameaças brasileiras de desinteressar-se da Liga. Dessa forma, quando Chamberlain chegou a Genebra para a sessão extraordinária da Assembleia, que deveria discutir a entrada da Alemanha em 7 de março de 1926, foi com instruções para negociar um assento extra apenas para a Espanha. O Brasil e a Polônia deveriam esperar outra oportunidade. O país foi informado do posicionamento britânico por um memorando entregue ao embaixador brasileiro em Londres, Regis de Oliveira. As recomendações de que o Brasil não insistisse na candidatura foram ignoradas por Felix Pacheco, contribuindo para a crise que se desenrolaria (Garcia, 2006).

Em 26 de fevereiro de 1926, Chamberlain, ao reafirmar que seu governo não apoiaria o pleito brasileiro na Assembleia extraordinária, pediu a Regis de Oliveira que Pacheco não usasse o veto. Segundo o político britânico, tal atitude colocaria em risco as relações bilaterais entre os países, levantaria a opinião do mundo todo contra o Brasil, encerraria qualquer esperança de o país obter um assento permanente e acarretaria o afastamento do Brasil da Liga e o seu ostracismo na arena internacional (Leuchars, 2001). 
A França, desde o lançamento da candidatura em 1923, mostrou-se favorável à ambição brasileira conforme demonstrou telegrama de Felix Pacheco a Melo Franco em Genebra, em 5 de setembro daquele ano, sobre comunicação da Embaixada francesa no Brasil a respeito de que, se a eventualidade de um aumento dos membros permanentes se apresentasse durante Assembleia, o Brasil poderia contar com o apoio cordial da delegação francesa ${ }^{28}$. No ano seguinte, em 1924, o embaixador do Brasil em Paris, Luís Martins Souza Dantas, informou Melo Franco sobre encontro com Édouard Herriot, presidente do Conselho de Ministros da França:

Na minha frente, ele redigiu um telegrama à delegação francesa junto à Sociedade das Nações, ordenando categoricamente que tomasse a iniciativa da apresentação do Brasil para um lugar permanente no Conselho. E, não contente com isso, ainda na minha frente, chamou o diretor-geral do Ministério, recomendando-lhe que imediatamente fizesse seguir o telegrama (Franco, 1955: p. 1231).

Diante da resistência alemã à candidatura polonesa, contudo, o apoio francês esvaneceuse, tendo em vista que a França não estava disposta a fomentar mais uma frente de atrito com seu rival germânico, em nome da promessa feita ao Brasil (Leuchars, 2001). Às vésperas de sua viagem a Genebra, o gabinete dirigido por Briand foi derrubado, e isso contribuiu para que o representante francês desempenhasse um perfil "baixo e moderado" nas reuniões do Conselho de 1926 (Rodrigues, 1995: p. 318).

No que tange ao apoio da Itália, o embaixador Souza Dantas foi encarregado de ir a Roma, no início de 1926, para acertar, diretamente com Benito Mussolini, a contribuição daquele país à causa brasileira. $\mathrm{O}$ sucesso da missão era dado como certo por Artur Bernardes. O presidente acreditava que a Itália não lhe poderia negar apoio, tendo em vista que o Brasil ficou a seu favor no incidente greco-italiano de Corfu, uma das questões políticas mais delicadas encaminhadas ao Conselho da Liga. O episódio ocorreu em 1923, quando a esquadra italiana bombardeou território grego em represália ao ataque sofrido por militares italianos, ao demarcar as fronteiras greco-albanesas. Dessarte, confirmando a expectativa de Bernardes, "Mussolini recebeu cordialmente o enviado brasileiro e lhe prometeu o voto italiano quando e se a candidatura fosse discutida, desde que nisso houvesse também entendimento com a França" (Garcia, 2006: p. 383).

${ }^{28}$ AHI, Liga das Nações, Delegações do Brasil, despachos e telegramas expedidos, 1920-1924, 274/2/4. 
A Bélgica posicionou-se de maneira constante, sem mais oscilações, no apoio ao pleito brasileiro. Em 1923, à época das sondagens realizadas pelo encarregado de negócios do Brasil, Mario de Pimentel Brandão, junto ao ministro do exterior belga, Henri Jaspar, o país foi favorável à candidatura, porém de forma vaga (Franco, 1955). Naquele ano, durante a $4^{\mathrm{a}}$ Assembleia, Melo Franco relatou a Pacheco saber que o governo belga havia enviado instruções ao seu representante no Conselho, Paul Hymans, para apoiar a fórmula Brasil-Espanha ${ }^{29}$. Finalmente, em 1926, a Bélgica manteve-se disposta a negociar, sem adotar atitude decisivamente favorável a nenhuma candidatura, a não ser à polonesa (Santos, 1995).

O Japão foi outro país que se manifestou favoravelmente à causa brasileira, conforme indica comunicação escrita do embaixador japonês Tatsuke destinada à Felix Pacheco, em 23 de setembro de 1925, em que confirmava o apoio do seu país aos desejos expressos pelo Brasil ${ }^{30}$. Quando foi convocada a Assembleia extraordinária para discutir a entrada da Alemanha, em março de 1926, o país manteve seu posicionamento a favor do Brasil, mostrando-se, aberto a considerar outros países candidatos (Santos, 1995).

Os demais países presentes no Conselho tinham posicionamentos variados. A Tchecoslováquia era favorável às candidaturas a assentos permanentes da Polônia, do Brasil e da Espanha. O Uruguai apresentava posicionamento algumas vezes ambíguo, mas havia demonstrado manifestações de simpatia à causa brasileira. A Espanha concordava com a concessão de assentos ao Brasil e à Polônia, desde que fosse igualmente contemplada com uma cadeira permanente. Finalmente, a Suécia, primeiro país a adotar uma atitude intransigente em relação ao alargamento do Conselho, era abertamente contrária a qualquer candidatura que não fosse a alemã (Santos, 1995).

Tendo em vista que a argumentação do Brasil consistia em ocupar, temporariamente, o assento destinado aos EUA no Conselho, obter o apoio deste país serviria de grande auxílio à campanha brasileira, mesmo a nação norte-americana não integrando formalmente a Liga. Dessa forma, por diversas vezes, o Brasil tentou obter o apoio dos EUA a sua candidatura (Santos, 1995). Em fevereiro de 1926, Pacheco solicitou ao embaixador brasileiro em Washington,

\footnotetext{
${ }^{29}$ Telegrama, Melo Franco a Pacheco, Genebra, 06/09/1923. AHI, Liga das Nações, telegramas recebidos, 19201924, 274/2/3.

${ }^{30}$ Telegrama, Pacheco a Afrânio de Melo Franco, 23/09/1925. AHI, SdN, DPB, telegramas expedidos, 1924-1926 (cópias), 274/3/4.
} 
Silvino Gurgel do Amaral, que intercedesse junto ao secretário de Estado norte-americano, Frank Kellog, para que os EUA fizessem um gesto de apoio ao Brasil nas principais capitais europeias - Londres, Roma, Paris, Estocolmo e Bruxelas ${ }^{31}$.

Amaral, contudo, recebeu retorno desfavorável de Kellog e relatou a Pacheco que não acreditava que o país pudesse contar "mais do que com as sinceras felicitações dos americanos para que entremos como membro permanente" ${ }^{32}$. Mesmo assim, Pacheco não desistiu e, após o veto brasileiro, nos meses em que o Brasil participou da comissão encarregada de estudar o aumento e a composição do Conselho, o chanceler buscou novamente conseguir o apoio dos EUA. O telegrama secreto enviado a Amaral, urgindo-o a ter uma conversa confidencial com o governo norte-americano, sobre a questão da Liga e do alargamento do quadro do Conselho ${ }^{33}$, em maio de 1926, serve de ilustração da esperança que Pacheco nutria em receber o respaldo norte-americano.

A Argentina estava afastada da Liga desde 1920, por isso o governo de Buenos Aires evitava comentar os acontecimentos em Genebra e adotar uma posição oficial quanto à candidatura do Brasil a membro permanente do Conselho. Apesar de o espírito de conciliação e cordialidade prevalecer nos contatos formais bilaterais estabelecidos entre as autoridades de ambos os países, sabia-se que a opinião do ministro das Relações Exteriores argentino, Angel Gallardo, e a de personalidades platinas eram desfavoráveis ao pleito brasileiro, como ilustrou a entrevista de Léon Suares, jurista e internacionalista argentino, ao jornal La Prensa ${ }^{34}$. Ademais, a mídia daquele país, constantemente, reiterava a visão de que o Brasil "representava unicamente o ponto de vista brasileiro e de nenhum modo o da América do Sul" (Garcia, 2006: p. 406).

\subsection{A crise de março e o veto brasileiro}

31 Telegrama, Pacheco a Amaral, 23/02/1926. AHI, Correspondência das Missões Diplomáticas Brasileiras, Embaixada em Washington, telegramas recebidos e expedidos, 1926, 235/3/10A.

32 Telegrama, Amaral a Pacheco, 24/02/1926. AHI, Correspondência das Missões Diplomáticas Brasileiras, Embaixada em Washington, telegramas recebidos e expedidos, 1926, 235/3/10A.

33 Telegrama, Pacheco a Amaral, absolutamente secreto, 13/05/1926. AHI, Correspondência das Missões Diplomáticas Brasileiras, Embaixada em Washington, telegramas recebidos e expedidos, 1926, 235/3/10A.

34 "Suarez declarou que a outorga de um assento permanente ao Brasil constituiria 'iniciativa perigosa' para as boas relações argentino-brasileiras." Apesar de essa opinião ter sido rechaçada pela chancelaria argentina como não representando a visão do governo, acreditava-se que Suarez expunha o pensamento que o governo não podia oficialmente expressar (Garcia, 2006: p. 385). 
A sessão extraordinária da Assembleia teve início em 8 de março de 1926. Quando os líderes se reuniram em Genebra, a crise tornou-se exclusivamente europeia, pois as negociações eram secretas, restritas aos países locarnistas, com países como Brasil e Espanha excluídos. O conflito centrava em torno da Alemanha, da Polônia e de seus respectivos apoiadores. O primeiro país a assumir uma posição mais rígida foi a Suécia, que autorizou seu chanceler a vetar qualquer país que não a Alemanha a entrar no conselho.

No dia 12 de março, o Conselho reuniu-se novamente, para debater o problema em torno da entrada da nação germânica. Todos os países presentes declararam-se dispostos a votar a favor da Alemanha, menos o Brasil e a Espanha, que foram solicitados a reconsiderarem suas candidaturas, deixando-as para momento mais oportuno. O representante espanhol, Quiñones de León, alegou que permitiria a entrada do país germânico, mas que a Espanha se retiraria da Liga se seu pleito não fosse atendido. Melo Franco indicou que as instruções recebidas do seu governo o impediam de concordar com seus colegas, tendo em vista que o país votaria contra a adesão da Alemanha ao Conselho como membro permanente. Diante das reprimendas recebidas dos demais delegados, especialmente de Chamberlain, o embaixador brasileiro enviou comunicação a Bernades em que tenta, sem sucesso, demovê-lo:

Pus o meu esforço e a minha alma na defesa dos nossos direitos, mas, diante do impasse em que nos achamos, reputo erro funesto assumirmos a responsabilidade do veto. Defensor da arbitragem, faremos cair o sistema dos pactos desta natureza, contraídos em Locarno, e assumiremos a tremenda responsabilidade da anulação dos tratados concernentes à politica de paz europeia, quando todos os outros membros do Conselho receiam diante desse gravíssimo perigo. O nosso crédito na Grã-Bretanha soerguido sofreria grave abalo. Pedi tempo para consultar o governo com urgência e rogo imediata resposta. Parece que a Espanha e a Polônia se retirarão da Liga e isto quase nos obriga a idêntica atitude. É a solução que proponho, depois de madura reflexão. Rogo urgentíssima resposta, antes de 24 horas. $^{35}$

Aumentavam, assim, as diferenças de posicionamento entre o representante em Genebra e o governo do Rio de Janeiro. O presidente e o chanceler brasileiros tinham uma visão superficial dos acontecimentos da Liga, e suas atitudes eram determinadas por uma percepção equivocada de "amor próprio" e de orgulho nacional e pelas repercussões internas que o assunto pudesse vir

${ }^{35}$ Telegrama, Melo Franco a Artur Bernardes, absolutamente confidencial, 12/03/1926. AHI, SdN, telegramas recebidos, 1926, 274/3/1. 
a ter. Mello Franco, apesar de ter-se manifestado contra o veto da Alemanha, não ameaçou renunciar sua função como representante brasileiro no Conselho, como fizera outrora como delegado na conferência pan-americana de 1923. A intervenção direta do presidente e do chanceler passou a caracterizar, daquele momento em diante, a política brasileira em Genebra (Soares, 1927).

Uma alternativa ao impasse entre os países locarnistas surgiu, em 13 de março, com a ideia de criar mais um assento não permanente para a Polônia, o que, com a entrada da Alemanha como membro permanente, manteria a mesma proporção entre ambas as categorias de lugares no Conselho. A Alemanha, no entanto, rechaçou a proposta. Em 15 de março, a Suécia reavaliou seu posicionamento, e seu representante, Östen Udén, anunciou que renunciaria seu assento no Conselho a favor da Polônia. A permuta seria desvantajosa para a nação germânica, que perderia um aliado em troca de um desafeto, e foi novamente rechaçada. O governo da Tchecoslováquia consentiu que seu representante, Edouard Benès, abdicasse da vaga temporária ocupada pelo país no Conselho para que, em seu lugar, fosse eleita uma nação neutra membro da Pequena Entente, preferivelmente os Países Baixos ou a Romênia (Scelle, 1927).

A aparente solução alcançada pelas nações europeias para a consecução dos acordos de Locarno não chegou a ser implantada, pois, na reunião seguinte, no dia 16 de março, Melo Franco anunciou que o Brasil mantinha o veto à entrada da Alemanha. Os embaixadores da França e da Grã-Bretanha no Rio de Janeiro tentaram persuadir Bernardes a mudar de posição. Similarmente, em 16 de março, as delegações dos países latino-americanos encaminharam ao governo brasileiro uma resolução unânime, pedindo que o presidente reconsiderasse o veto:

Tenant compte de la gravité de la situation actuelle de la Société des Nations, tenant compte des intérêts de la paix universelle et tenant compte de la nécessité que les États américains exercent une action en faveur de la réconciliation entre les peuples d'Europe, expriment à M. l'ambassadeur de Melo Franco le désir desdites délégations que le Brésil facilite, par les moyens qu'il estime les plus opportuns, l'accord unanime du Conseil, afin de solutionner les difficultés qui empêchent sa décision. ${ }^{36}$

Ambas as iniciativas não lograram nenhum resultado, e, na reunião do dia 17 de março, Melo Franco vetou a entrada da Alemanha. Em sua alocução, o representante brasileiro

\footnotetext{
${ }^{36}$ Monção do delegado do Paraguai, Sr. Caballero, em nome das delegações do Chile, da Colômbia, de Cuba, da Guatemala, da Nicarágua, da República Dominicana, de El Salvador, do Uruguai e da Venezuela (Soares, 1927: p. 135).
} 
reivindicou para a América uma representação mais justa e numerosa no Conselho, negou que estivesse movido por interesses egoístas ou de orgulho nacional e defendeu que "nous ne devrons pas perdre de vue que l'ouvre admirable de Locarno doit rentrer dans le cadre de la Société des Nations et non pas la Société des Nations dans la construction politique de Locarno" (Mello Franco apud. Soares, 1927: p. 262) ${ }^{37}$.

Na sequência, Chamberlain proferiu discurso em que congratulou as ofertas generosas da Suíça e da Tchecoslováquia de ceder seus lugares no Conselho e observou ser verdadeiramente trágico que outro obstáculo viesse a postergar a entrada da Alemanha. O pronunciamento de Briand reforçou os pontos mencionados pelo colega britânico e chamou o empecilho à entrada da Alemanha de "paralisias humilhantes" e de "profunda decepção". O representante do Japão, Visconde Ishii, reiterou a expressão do delegado francês, afirmando ser profunda decepção que "des intérêts particuliers se sont opposés aux intérêts généraux, au bien commun de la Société des Nations" ${ }^{\prime 38}$. Assim, após a manifestação generalizada de frustração diante da impossibilidade de resolver a questão relativa à entrada da Alemanha, a Assembleia decidiu postergar as deliberações até setembro daquele ano.

É importante observar que as alocuções dos países presentes à reunião do Conselho culparam o Brasil pelo fracasso nos tratados de Locarno, sem, contudo, fazer qualquer menção aos problemas relativos à entrada da Polônia e às propostas da Tchecoslováquia e da Suécia (Soares, 1927). O Brasil saiu como vilão, embora, em uma análise mais detida, tenha havido algo de providencial na atitude brasileira, conforme apontou Melo Franco em telegrama a Pacheco, no dia 25 de março:

Para substituir a Tchecoslováquia havia disputa entre a Romênia e a Iugoslávia, isto é, uma ameaça de dissolução da Petite Entente, como mau princípio, além da candidatura da Holanda, amparada pelos estados germanófilos. Em resumo: se o Brasil houvesse retirado o veto, todo esse imbróglio viria a público e a Assembleia talvez ainda estivesse esperando o desenlace. $^{39}$

Contrariamente ao que é comumente afirmado, portanto, o Brasil não destruiu a obra de Locarno. O veto brasileiro, longe de agravar a situação, ajudou a desarmar possível crise,

\footnotetext{
${ }^{37}$ Discurso disponível em Soares, 1927. Anexo III, p. 260-294.

${ }^{38}$ Discursos disponíveis em Soares, 1927. Anexo III, p. 260-294.

${ }^{39}$ AHI, SdN, DPB, telegramas recebidos, 1926, 274/3/1.
} 
fornecendo um período de reflexão para que uma solução satisfatória pudesse ser amadurecida. Ao usar a prerrogativa do veto, o país acabou servindo de bode expiatório, pois "carregou a culpa pela crise sobre seus ombros, onde não pertencia integralmente, e, assim, impediu um confronto sério entre as potências europeias" (Leuchars, 2001: p. 138).

A repercussão interna do veto brasileiro à entrada da Alemanha conferiu um momento de efêmera e artificial popularidade ao conturbado mandato de Artur Bernardes. Considerando a censura existente pelo estado de sítio, a população ficou alheia às repercussões negativas veiculadas ao redor do mundo:

Não se conhecem, em nossa terra, em geral, as manifestações havidas contra nossa atitude, na Europa e nos Estados Unidos. Nossa imprensa, ou não foi informada, ou não divulgou as noticias recebidas.

Raras vozes dissentindo, resumem-se: o Brasil, por vaidade nacional e incompreensivel orgulho, fez fracassar o restabelecimento da paz real, que se ia esboçando na Europa. (Calógeras, 1930: p. 177)

Compreendem-se, assim, elogiosas menções à ação em Genebra pelos jornais oficiosos e homenagens recebidas pelo chanceler e pelo presidente. Em 18 de março, Pacheco recebeu tributo aparentemente espontâneo dos servidores do Ministério sob o seu comando. O Itamaraty divulgou nota afirmando que os funcionários falavam em nome de todos os brasileiros. Interessante observação fez o jornal A Tribuna, que questionou quem os havia concedido o direito de representar o povo ${ }^{40}$. De forma análoga, Bernardes recebeu uma manifestação de apoio em Petrópolis, em 21 de março, com cerca de 3 mil pessoas. Descobriu-se, contudo, que os participantes eram, em sua maioria, funcionários públicos solicitados a comparecer ao evento (Garcia, 2006). Apesar das restrições à liberdade de imprensa, a mídia brasileira de oposição logrou manifestar sua reprovação pela candidatura do Brasil, considerada "um conflito de vaidades" e "delírio de grandeza", e clamava que o país se retirasse da Liga (Garcia, 2006: p. 396).

No que tange à mídia mundial, a reação foi majoritariamente negativa. Jornais franceses, como o Le Matin, e argentinos, como o La Prensa, responsabilizaram o Brasil pelo adiamento da entrada da Alemanha. A imprensa alemã, como ilustrou o periódico Berliner Tageblatt, apontou falhas na argumentação brasileira, que justificava sua pretensão com a tese de ser o representante

\footnotetext{
${ }^{40}$ BN, Seção de Manuscritos, Coleção Melo Franco, SdN, recortes de jornais, 1926, pasta 380.
} 
do continente americano, embora nenhum país concordasse em auferir-lhe essa prerrogativa. Os jornais norte-americanos, como o The New York Times, depreciaram a política brasileira na Liga e levantaram a suspeita de que outro país estivesse por trás da atitude brasileira. Aliás, isso foi levantado por diversos jornais, como os franceses Le Figaro e Le Temps. A suspeita de que a Itália tivesse alguma ascendência sobre o Brasil foi mencionada no britânico Daily Herald, afirmando ser o representante brasileiro chamado nos círculos da Liga de "Mellolini Franco" (Garcia, 2006; Santos, 1995).

\subsection{Os trabalhos da comissão e a saída do Brasil da Liga}

No dia seguinte ao veto brasileiro à Alemanha, 18 de março, a Assembleia determinou a criação de uma comissão encarregada de examinar a composição do Conselho e o modo de eleição dos seus membros. A comissão, presidida pelo chanceler suíço, Giuseppe Motta, foi composta pelos dez países integrantes e por mais cinco Estados convidados: a Alemanha, a Argentina, a China, a Suíça e a Polônia. A participação da nação germânica incomodou o Brasil pelo fato de aquele país estar na comissão, sem pertencer, formalmente, à Liga. A presença do vizinho platino foi percebida, ademais, como uma forma de punir o Brasil e de enfraquecer sua posição no Conselho, tendo em vista a Argentina ter um histórico de rivalidade e oposição à argumentação desenvolvida pelo Brasil (Santos, 1995; Garcia, 2006).

Felix Pacheco indicou o assessor técnico da Delegação Permanente na Liga, Elizeu Fonseca de Montarroios, para representar o Brasil na comissão. O fato de Melo Franco ter sido excluído dos trabalhos do grupo era indício da busca do presidente por maior controle nas ações brasileiras na comissão e, possivelmente, sinalizava o desacordo que havia entre Melo Franco e o governo central no Rio de Janeiro. As divergências entre ambos iriam acentuar-se nos meses seguintes como demonstrou o desenrolar dos acontecimentos que levaram à retirada do Brasil. Contudo, a troca de Melo Franco, que gozava de amplo respeito e admiração dos demais delegados, por Montarroios "was an unfortunalety choise, and he quickly aroused the dislike of his colleagues" (Leuchars, 1983: p. 298), acarretando dificuldade adicional às negociações do Brasil.

Em comunicações trocadas com Pacheco, Melo Franco informou sua visão de qual deveria ser a estratégia do Brasil após o veto. O plano discorria sobre três possibilidades que 
consistiam em, primeiramente, buscar um entendimento imediato com a Argentina, para pedir a supressão de todos os lugares permanentes. Caso isso fosse impossível, pela oposição das grandes potências ou pelo veto de alguma delas, reclamar-se-iam dois lugares permanentes para a América e dois ou três não permanentes para o continente americano. Sendo isso igualmente impraticável, retirar-se-ia o Brasil da Liga das Nações ${ }^{41}$.

Apesar da tradicional cordialidade que regia as relações entre os representantes diplomáticos, a animosidade das principais potências europeias contra o Brasil, após o veto, era palpável. A Grã-Bretanha, em particular, ficou enfurecida com o fato de um país do segundo escalão ter impedido a concretização de suas aspirações. O Brasil via suas chances de alcançar o almejado posto permanente no Conselho como remotas, , por conseguinte, seu interesse nos trabalhos da comissão também diminuiu (Leuchars, 1983).

Durante a primeira reunião da comissão, em 10 de maio, Montarroios questionou a então vigente divisão dos membros do Conselho em duas categorias e defendeu que a proposição de transformar todos os assentos do Conselho em eletivos, a qual tinha o apoio de grande parte da América Latina, deveria ser estudada. A posição que o Brasil adotou, naquele momento, era similar à que havia sido defendida pela delegação argentina em 1920. É interessante notar a mudança de atitude do Brasil, que, percebendo não ter mais chances de ascender a um assento permanente, passou a advogar pela supressão daqueles postos.

O posicionamento brasileiro não encontrou respaldo, todavia, nas alocuções dos representantes dos dois países latino-americanos na comissão, que eram Le Breton, da Argentina, e Guani, do Uruguai, alinhados com a proposição de Robert Cecil, também apoiada pelo representante francês, Paul-Boncour. O projeto britânico instituía terceira categoria de membros, os semipermanentes, que poderiam ser indefinidamente reeleitos por uma maioria de dois terços da Assembleia. Se adotada, a proposta elevaria o número de cadeiras temporárias a nove e acarretaria a eleição de todos os membros rotativos do Conselho já na Assembleia de setembro. Esta era uma forma de a Grã-Bretanha alcançar um compromisso com os países postulantes a assentos permanentes, como o Brasil e a Espanha, e impedir novo veto na vindoura reunião do Conselho (Santos, 1995).

\footnotetext{
${ }^{41}$ Telegrama, Melo Franco a Pacheco, 19/03/1926. AHI, SdN, DPB, telegramas recebidos, 1926, 274/3/1.
} 
O Brasil absteve-se na votação da primeira leitura do projeto, alegando que "a comissão havia invertido a ordem e o método dos trabalhos" (Garcia, 2006: p. 407), pois, ao ocupar-se, primeiro, dos membros temporários, postergava e desviava a atenção da discussão central do aumento dos assentos permanentes. A recusa em aceitar o roulement de todos os países latinoamericanos demonstrou, contudo, a incoerência do posicionamento do Brasil em defesa do ideal americanista de igualdade dos Estados. Os dirigentes do Brasil viam-no como um Estado diferenciado perante os demais vizinhos, um primus inter paris na América Latina (Garcia, 2005).

Isto se evidenciou em correspondências trocadas entre políticos brasileiros, em que ocorriam referências pejorativas aos países latino-americanos. Por exemplo, em telegrama de dezembro de 1925, destinado a Melo Franco, Pacheco refere-se às nações da América Latina como "gente que tudo atrapalha e dificulta, fazendo papéis ridículos e capitulando no fim como carneiro"; "nações sem responsabilidade internacional como a nossa" ${ }^{42}$. No mesmo ano, Pacheco escreve a Melo Franco sobre relato da reunião dos países latino-americanos:

É realmente pitoresco e dá até vontade de rir o desconcerto de nossos irmãos continentais. Cada vez compreendo mais e melhor a sua bonhomia no lidar com esse pessoal difícil que a si próprio não se entende e que a tanta canseira nos obriga ${ }^{43}$.

Não obstante o discurso idealista de defesa do continente americano, o Brasil movia-se guiado por premissas realistas de ampliação de seu prestígio e status na arena internacional. Se fosse genuína a argumentação desenvolvida de que o país defendia os direitos da América contra um Conselho exclusivamente europeu, o Brasil bem poderia aceitar a proposta de conceder três lugares temporários reservados a essa região, o que permitiria a rotação democrática entre todos, sem beneficiar nenhum país isoladamente.

Na sessão da comissão, de 17 de maio, o projeto de Robert Cecil foi aprovado em primeira leitura. De acordo com a proposta britânica, a próxima Assembleia, em setembro, já procederia à eleição de nove membros temporários: um terço deles teria mandato de três anos, outro terço teria de dois anos, e o último terço, de um ano. Seguindo o princípio da repartição geográfica, haveria a reserva de três assentos temporários para países da América Latina, os

\footnotetext{
42 Telegrama, Pacheco a Melo Franco, 13/12/1925. AHI, SdN, DPB, telegramas expedidos, 1924-1926 (cópias), $274 / 3 / 4$.

${ }^{43}$ Telegrama, Pacheco a AMF, 26/09/1925. AHI, SdN, DPB, telegramas expedidos, 1924-1926 (cópias), 274/3/4.
} 
quais seriam ocupados em um sistema de revezamento. A segunda leitura do projeto foi fixada para 28 de junho, quando seria examinada "a questão do aumento dos assentos permanentes e as demandas formuladas por Brasil, China, Espanha, Pérsia e Polônia" (Santos, 1995: p. 228).

Em maio de 1926, Pacheco fez derradeira tentativa de arregimentar apoio dos países latino-americanos com o envio de um memorando a todos os Estados americanos na Liga e aos EUA. O chanceler reclamava da injustiça com o continente, acusava as grandes potências de tratar a América Latina como os Bálcãs, exercendo uma "política de dividir para reinar", e conclamava a região a unir-se em um só voz em Genebra (Leuchars, 1983: p. 300). Apesar de não declarar com clareza no memorando, a proposta de Pacheco, explicitada em circular telegráfica que seguiu a todos os postos diplomáticos brasileiros do continente, sugeria a criação de três assentos permanentes no Conselho, destinados às Américas britânica, espanhola e portuguesa (Garcia, 2006).

Diante do malogro das estratégias de união do continente a favor do pleito brasileiro e do isolamento crescente do Brasil na comissão, o país preparou sua retirada da Liga. Em 2 de junho, Pacheco enviou telegrama com carta de resignação do assento temporário do Brasil no Conselho. A instrução do chanceler determinava que a mensagem fosse lida por Melo Franco no início da $40^{\mathrm{a}}$ sessão do Conselho. A exposição de motivos elaborada pelo governo brasileiro era extensa, continha mais de cinquenta parágrafos e tecia inúmeras críticas à Sociedade das Nações. Uma delas seria a de perpetuar práticas diplomáticas de negociações secretas, restritas às grandes potências conforme indica o trecho:

Il est déjà temps de favoriser davantage l'application des principes et des bonnes doctrines de la politique internationale. Pourquoi ne pas rendre publiques les ententes qui seraient intervenues à côté des pactes? Que mal pourrait-il y avoir? Procéder à des négociations, seulement entre les plus forts, pour éviter que les faibles ne résistent pas à l'honneur d'y adhérer n'est plus une erreur nouvelle, qu'en cas affirmatif on pourrait peut-être excuser $^{44}$.

Melo Franco não concordou com a carta preparada por Bernardes e Pacheco, a qual considerou ofensiva. Em 5 de junho, o representante brasileiro em Genebra encaminhou

\footnotetext{
${ }^{44}$ Telegrama do Governo do Brasil ao secretário-geral da Sociedade das Nações, Genebra, 10/06/1926. Soares, 1927, Anexo IV, p. 323-338.
} 
comunicação dirigida ao chanceler, em que buscou demovê-lo de fazer a declaração ${ }^{45}$ e solicitou mais liberdade de ação na defesa dos interesses brasileiros. A resposta veio do presidente, que escreveu a Melo Franco, para convencê-lo das instruções recebidas e do apoio da opinião pública brasileira de que desfrutaria a atitude do governo. Melo Franco não se convenceu e ameaçou pedir demissão. Bernardes argumentou, então, que a exposição de motivos havia sido cuidadosamente preparada e insistiu que fosse lida pessoalmente, mas concedeu que a leitura ocorresse ao final da sessão e não no início, como previamente solicitado (Leuchars, 1983; Santos, 1995; Garcia, 2006).

No dia 10 de junho, ao final da sessão trimestral do Conselho, Melo Franco pronunciou a alocução em que comunicava, oficialmente, a renúncia ao assento ocupado pelo Brasil no Conselho. A declaração preparada por ele mantinha a essência da anterior, reafirmando a tese da representação continental, ponto basilar da argumentação brasileira, porém de forma mais sucinta, histórica, jurídica e menos hostil às grandes potências. Após a alocução do representante brasileiro, o presidente da reunião, o delegado uruguaio, enalteceu Mello Franco e as credenciais do Brasil. Em seguida, Chamberlain lamentou o fato, mas afirmou que o conselho não podia ser composto por critérios de simpatia pessoal e afinidades nacionais. O delegado da Itália, Scialoja, levantou a questão de ordem jurídica de que não era o Conselho quem deveria aceitar a demissão brasileira, mas, sim, a Assembleia e que o Brasil devia permanecer até que isso ocorresse, para não atravancar os trabalhos do órgão (Soares, 1927).

No mesmo dia, a exposição de motivos preparada pelo governo brasileiro foi entregue por Melo Franco ao secretário-geral da Liga. Em seu último parágrafo, previa a notificação, em momento oportuno, da "résolution de décliner l'honneur d'appartenir à la Société des Nations" ${ }^{46}$. Entretanto, não satisfeito com a resistência de Melo Franco em ater-se às suas instruções, Pacheco remeteu, menos de 48 horas depois, no dia 12 de junho, um telegrama sobre a decisão do Brasil de sair da Liga a Eric Drummond sem que Melo Franco fosse comunicado. O representante brasileiro protestou junto ao presidente Bernardes "il est étrange que la notification a été faite directement (...) sans m'a avoir donné, M. le Ministre, aucun avis préalable, procédure

\footnotetext{
${ }^{45}$ Para Melo Franco, "il ne convient absolument pas, dans la phase actuelle de la question, de faire les déclarations proposées (...) car les études de la commission de réforme du Conseil ne sont pas finies et par conséquent nos observations critiques seraient hors propos" (Melo Franco apud. Santos, 1995: p. 231).

${ }^{46}$ Telegrama do Governo do Brasil ao secretário-geral da Sociedade das Nações, Genebra, 10/06/1926. Soares, 1927, Anexo IV, p. 323-338.
} 
qui me diminue face au Secrétaire général (...)". As respostas recebidas tanto do presidente quanto de Pacheco, apesar do tom conciliatório, não escondiam as tensões e os mútuos ressentimentos existentes entres as autoridades brasileiras (Santos, 1995; Garcia, 2006).

A retirada do Brasil da Liga $^{47}$ foi recebida de maneira consensualmente positiva pela opinião pública interna, num raro momento em que o tema despertou seu interesse. Como a imprensa de oposição defendia que o país adotasse uma postura isolacionista em relação às negociações europeias realizadas em Genebra, com o abandono da Sociedade das Nações, Bernardes apropriou-se do discurso oposicionista e conseguiu, finalmente, a aprovação convergente de diversos estratos sociais em torno de sua política externa. Dias após a comunicação da retirada, em 26 de junho, Pacheco pronunciou alocução e enalteceu o continente americano: "Nós somos um grande grupo de nações à parte, com sua própria ética e peculiaridades precisas e bem definidas" (Pacheco apud. Garcia, 2006: p. 417), marcando o retorno do Brasil a uma política pan-americanista e de aproximação com os EUA.

Houve a suposição, veiculada em matéria do periódico O Jornal, de Assis Chateaubriand, de que Bernardes nunca havia, de fato, pretendido que o Brasil ocupasse um assento permanente no Conselho. O único objetivo do presidente teria sido o de "provoke a dramatic interest in Brazil throughout the world, and when that was done to leave the League" ${ }^{48}$. Se era esse o intento do presidente, foi bem-sucedido, tendo em vista que a retirada do país da Liga teve ampla repercussão internacional (Santos, 1995: p. 235; Leuchars, 1983: p. 305; Soares, 1927: p. 142). $\mathrm{Na}$ imprensa europeia, as matérias veiculadas refletiam um misto de consternação com o prestígio da Liga, por tornar-se mais europeizada, e de chacota, como a charge que mostrava o Brasil como "pequeno cão vira-lata deixando sorrateiramente a Liga" (Garcia, 2006: p. 416).

No dia seguinte ao do anúncio da retirada, Bernardes recebeu a visita do embaixador norte-americano, Edwin Morgan. O presidente brasileiro alegou ter o país recebido a felicitação dos EUA por sua atitude de sair da SdN. O Departamento de Estado apressou-se em negar essa informação, reafirmando a política de distanciamento dos EUA em relação aos assuntos da Liga, mantida desde 1919. A Argentina recebeu a notícia com certo alívio, e o fim da tentativa brasileira de "representar" seus vizinhos na Europa contribuiu para reaproximar os dois países. O

\footnotetext{
${ }^{47}$ O Brasil anunciou a retirada da Liga em junho de 1926, mas esta só passou a vigorar, de fato, em 1928, pois "a denúncia do tratado é efetivada apenas depois de dois anos do anúncio da retirada" (Braga, 2008: p. 128).

${ }^{48}$ Alston a Chamberlain. Brazil and League of Nations, 09/02/1927. FO 371/11964, rolo 34.
} 
Chile foi o grande beneficiado com a saída do Brasil da Liga, e, consequentemente, do Conselho, pois recebeu o assento temporário que o país ocupava (Soares, 1927: p. 141).

\subsection{O isolamento esplêndido e o possível retorno à Liga}

O fim do mandato de Bernardes e a substituição de Felix Pacheco do comando do Itamaraty geraram um sentimento de alívio dentro e fora do país. A gestão do presidente era extremamente centralizada e autoritária, exigindo que todos os assuntos passassem pelo seu crivo como atestou o embaixador britânico, Sir Beilby Alston: "foreign representatives here have found it almost impossible to get questions of any importance settle without going to the President in person" ${ }^{49}$. A administração da chancelaria brasileira era considerada ineficiente e foi igualmente alvo de críticas: "the carrying on of ordinary diplomatic business was peculiarly difficult and rarely successful" ${ }^{150}$.

A eleição de Washington Luís Pereira de Souza, em novembro de 1926, foi recebida, com entusiasmo, pelo corpo diplomático residente no país. Apesar de o novo presidente ter sido indicado por Bernardes e de saber-se que o antigo presidente lhe havia pedido para não reverter suas políticas bruscamente, acreditava-se que Washington Luís fosse livre da "narrowmindedness and suspicious ignorance of his predecessor" ${ }^{51}$. Esperava-se, portanto, que a mudança de governo abrisse possibilidades de reaproximação com os parceiros europeus, cujas relações haviam sido abaladas com a "aventura" genebrina do Brasil. Contudo, o quadriênio de 1926 a 1930 seria marcado pelo retraimento das relações internacionais brasileiras, denominado, em artigo do O Jornal, de "isolamento esplêndido": "Washignton Luis' programme may be summed up in a few words: the least possible contact with other nations; or rather only such contact as is indispensable to any State which lives in international society" ${ }^{52}$.

A postura isolacionista do presidente foi refletida na escolha de seu chanceler, tendo em vista que nomes fortes para o cargo, como o de Afrânio de Melo Franco e o de Raul Fernandes, foram preteridos pelo de Octavio Mangabeira. Engenheiro, o novo chefe do Itamaraty havia

\footnotetext{
${ }^{49}$ Alston a Chamberlain. Report on Brazil for 1926. FO 371/11967, rolo 35.

${ }^{50}$ Alston a Chamberlain. Report on Brazil for 1926. FO 371/11967, rolo 35.

${ }^{51}$ Alston a Chamberlain. Leading personalities in Brazil, 06/04/1927, FO 371/11964, rolo 34. Annual Report, 1927. FO 371/12744, rolo 36.

${ }^{52}$ Alston a Chamberlain, muito confidencial, 21/02/1927. FO 371/11964, rolo 34.
} 
causado boa impressão em Washington Luís, com seu desempenho na política baiana ${ }^{53}$, focalizou sua gestão à frente da chancelaria em questões regionais ${ }^{54}$ e na modernização do Itamaraty (Doratioto, 2012). O continente americano, desde o início da década, não era objeto de devida atenção por parte dos dirigentes do país ${ }^{55}$. O status do Brasil encontrava-se enfraquecido, especialmente se comparado ao da sua vizinha, a Argentina, que havia expandido ferrovias e atraído as produções das repúblicas vizinhas em "vast political programme which is being carried out while Brazil is asleep" ${ }^{56}$.

Mangabeira nutria uma admiração pessoal pelos trabalhos da Liga. Apesar de ter promovido gestões junto ao presidente, não foram suficientemente fortes e eficientes a ponto de demovê-lo de sua atitude isolacionista ${ }^{57}$. O desinteresse da opinião pública pelo tema e a percepção majoritariamente desfavorável expressa na imprensa contribuíram para que o chanceler perdesse o interesse pelo tema ${ }^{58}$.

No plano internacional, iniciaram-se movimentos para tentar reverter a retirada do país da Liga. Ironicamente, o país que mais hostilizou o veto brasileiro foi o que liderou as iniciativas. A Grã-Bretanha tinha seu prestígio intimamente atrelado ao sucesso da organização genebrina e estava "especially concerned to restore its diplomatic reputation by persuading those who had previously defied it to return to Geneva" (Leuchars, 1983: p. 310). Além da Grã-Bretanha, outra potência europeia cujo declinante prestígio atrelava-se à Liga, a França, igualmente, engajou-se nos esforços por trazer o Brasil novamente à organização.

A primeira intervenção britânica, junto ao governo brasileiro, a favor da Liga, ocorreu quando da visita não oficial do ex-primeiro ministro britânico Lloyd George, ao país, em janeiro de 1928. Em banquete ofertado a 70 pessoas, no Palácio Itamaraty, pelo ministro das Relações Exteriores, George, ao realizar brinde de agradecimento, mencionou que não poderia deixar de expressar sua esperança de que o Brasil permanecesse na Liga das Nações, que tanto ainda

\footnotetext{
${ }^{53}$ Alston a Chamberlain, muito confidencial, 21/02/1927. FO 371/11964, rolo 34.

${ }^{54}$ Como ilustração, podem-se citar as gestões de Mangabeira na definição das demarcações lindeiras com os vizinhos Bolívia, Peru, Paraguai e Uruguai, na questão da navegação do rio Paraguai. Alston a Chamberlain, 20/06/1927. FO 371/11964, rolo 34.

55 "The press here [in Brazil] is beginning to remark upon the tendency of Brazil to pay too much attention to European countries and the United States of America to the detriment of her political and commercial relations with neighbouring South American Republics". Brazil's Foreign Relations, 16/12/1920. FO 371/4440, rolo 17.

${ }^{56}$ Brazil's Foreign Relations, 16/12/1920. FO 371/4440, rolo 17.

${ }^{57}$ Alston a Chamberlain, confidencial, Annual Report, 1928. FO 371/13468, rolo 37.

${ }^{58}$ Alston a Chamberlain, confidencial, Annual Report, 1927. FO 371/12744, rolo 36.
} 
poderia fazer para avançar o destino da humanidade ${ }^{59}$. A declaração foi considerada "a gaffe beyond pardon"60 e, apesar da boa receptividade dos convidados ali presentes, a reação da imprensa foi unanimemente negativa. Com a exceção do periódico O Jornal, todos aproveitaram a ocasião para atacarem a Liga, seus trabalhos e, principalmente, a fala do político britânico como ilustra o trecho de artigo veiculado em O Paiz:

Does Mr Lloyd George think that Brazil has lost all shame and is ready to go back to Geneva after being ill-treated, despised, made ridiculous and thrown out from the League? She could only conceivably return if they gave her the permanent seat for which she had asked. But it is exceedingly sad that Mr Lloyd George considers that Brazil has no sense of international shame s1. $^{\text {. }}$

A posição desfavorável à Liga da opinião pública nacional foi reiteradamente alegada por Mangabeira como um dos impedimentos ao retorno do Brasil à Sociedade das Nações. Em conversa com o embaixador britânico em meados de 1928, relatada posteriormente ao Foreign Office, Mangabeira disse que a imprensa inteira era contrária à Liga e "it might be difficult after two years for Brazil to go back on her word, and that public opinion was against it and might regard it as a humiliation" ${ }^{62}$. Alston afirmou a seu colega que não deixasse a opinião pública interferir no bom julgamento do presidente do que era melhor para o país ${ }^{63}$. O argumento brasileiro, como o representante britânico notou em seus comentários a Chamberlain, era falacioso, pois a opinião pública brasileira em questões internacionais resumia-se a uma porcentagem ínfima da população, e o governos da Primeira República logravam impor suas políticas quando assim desejavam ${ }^{64}$.

No final de março de 1928, novas tratativas foram feitas, dessa vez, oficiais, pelo Conselho da Liga e pelos governos da França e da Grã-Bretanha. No dia 9, o colombiano

\footnotetext{
${ }^{59}$ Alston a Chamberlain, 11/01/1928. FO 371/12743, rolo 36.

${ }^{60}$ Comentário do jornal O Paiz. Summay of Press Comments on M. Lloyd Geroge's Speech at the Itamaraty Palace, 07/01/1928. FO 371/12743, rolo 36.

${ }^{61}$ Matéria do jornal O Paiz. Summay of Press Comments on M. Lloyd Geroge's Speech at the Itamaraty Palace, 07/01/1928. FO 371/12743, rolo 36.

${ }_{62}^{6}$ Alston a Chamberlain, confidencial, 17/05/1928. FO 371/12743, rolo 36.

${ }^{63}$ Alston a Chamberlain, confidencial, 17/05/1928. FO 371/12743, rolo 36.

64 "As for the public opinion, it can hardly be said to exist in Brazil, at least as regards questions of external affairs. The enthusiasm and passions of the people are reserved exclusively for matters of internal politics and municipal scandals, while it is almost impossible to get the average cultured Brazilian to discuss any question other than the most trivial. As for the average Deputy, he is just vaguely aware that other countries do exist outside the confines of the American continent. This state od affairs tends to strengthen very considerably the autocratic powers wielded by the President, and even a man of lesser obstinacy would have little difficulty in imposing his will in this respect". Alston a Chamberlain, confidential, Annual Report, 1927. FO 371/12744, rolo 36.
} 
Francisco José Urrutia, então presidente do Conselho da $\mathrm{SdN}$, aprovou uma resolução, enviada ao governo brasileiro, fazendo um apelo para que o país reconsiderasse sua retirada da organização. A Espanha, que também se havia afastado da Liga durante a crise de março de 1926, recebeu semelhante solicitação. A nação hispânica convenceu-se de retirar sua resignação e voltou à Liga, sem fazer exigências ou impor restrições (Garcia, 2006).

Em 30 de março, o embaixador francês residente no Brasil, Comte de Robien, encontrouse com Mangabeira, para comunicar-lhe o apelo pessoal do primeiro ministro francês, Aristide Briand, feito por meio de telegrama, em 28 de março, clamando o Brasil a tomar "une décision qui intéresse tous les peuples associés à l'ouvre de la paix" de retornar à Sociedade das Nações ${ }^{65}$. Mangabeira contrapôs que, apesar de o país continuar a manter boas relações com a organização e aceitar os convites para participar de suas conferências, seria difícil reverter sua saída. Diante da resposta, Robien indagou "whether there were no conditions on which Brazil woud be prepared to come back". Mangabeira respondeu que o presidente requeriria um assento permanente para o país, mas que essa informação deveria ser tratada de modo estritamente confidencial $^{66}$.

Em 31 de março, o embaixador britânico, Sir Beilby Alston, encontrou-se com o chanceler brasileiro e transmitiu-lhe as palavras de Austen Chamberlain, reiterando o pedido do presidente do Conselho e do primeiro ministro francês de que o Brasil voltasse à Liga ${ }^{67}$. Mangabeira respondeu que iria consultar o presidente em sua próxima audiência presidencial, no dia 3 de abril. No dia 7 de abril, Alston ligou para Mangabeira averiguando qual havia sido a resposta do presidente. O chanceler brasileiro disse que uma nota oficial do governo seria encaminhada à Liga como resposta ao pedido do presidente do Conselho e que não seriam feitas declarações até então. Em 15 de maio, o Itamaraty enviou a nota com cópia aos governos britânico e francês, em que, cordialmente, atestava que o país "could find no determining factor for altering a situation already clearly defined, since the contingencies which had brought that situation about were in no way changed"68. A nota concluía que, apesar de a posição do Brasil

\footnotetext{
${ }^{65}$ Alston a Chamberlain, confidencial, 17/05/1928. FO 371/12743, rolo 36.

${ }^{66}$ Alston a Chamberlain, confidencial, 17/05/1928. FO 371/12743, rolo 36.

67 Mangabeira a Régis de Oliveira, reservado, 07/04/1928. AHI, Londres, telegramas expedidos, 1927-1930, 219/3/5.

${ }^{68}$ Alston a Chamberlain, confidencial, 23/02/1929. Annual Report, 1928. FO 371/13468, rolo 37.
} 
não permitir-lhe ensejar uma filiação permanente na Sociedade das Nações, o país iria continuar a colaborar com a organização na prestação de serviços à humanidade e à civilização ${ }^{69}$.

\subsection{Avaliação da política brasileira para a Liga}

A decisão de sair da Liga enfrentou a resistência de Melo Franco e foi imputada a Artur Bernardes, que esperava ganhar legitimidade perante a população brasileira, com a política de "vencer ou não perder" (Garcia, 2006: p. 375), como o próprio presidente a nomeou. A grande distância que separava o país da problemática da paz no Velho Continente e a ausência de qualquer experiência internacional tanto do presidente quanto de seu chanceler, considerando que "neither had ever been out of Brazil nor had any experience of a nature to give him a broad outlook on the difficult and complicated problems of European politics"70, explicam a forma como foi gerenciada a crise de março de 1926. O temperamento inflexível de Bernardes ${ }^{71}$, notório tanto nos meios internos quanto nos círculos internacionais, contribuiu para que o país fizesse a opção pelo desligamento da Liga.

A meta de transformar o posto temporário que o Brasil dispunha no Conselho em um assento permanente, eleita pelo governo Bernardes como objetivo principal de sua política externa, era, na visão de muitos autores, inatingível e irrealista:

Embora o Brasil fosse o maior país da América Latina e o único a ter participado ativamente ao lado dos aliados durante a guerra, era militar $e$ economicamente fraco, fato que garantia que os principais aliados europeus não o aceitariam como parceiro de mesmo nível. O único fator que poderia ter contrabalanceado essa falta de peso específico na balança internacional teria sido a adesão unânime da América Latina à pretensão brasileira, mas esse apoio conspicuamente inexistiu (Hilton, 1986: p. 19).

A eleição dessa meta de política externa, na forma como foi conduzida, decorreu da visão equivocada do status internacional desfrutado pelo país no contexto após a Primeira Guerra. O presidente Artur Bernardes, inconformado com o papel imputado ao Brasil pelas grandes potências, alimentava sonhos de grandeza, mas que não eram correspondidos com metas e projetos substanciais nas relações exteriores, formando a dicotomia entre "interesses limitados e

${ }^{69}$ Mangabeira a Régis de Oliveira, confidencial, 13/04/1928. AHI, Londres, telegramas expedidos, 1927-1930, $219 / 3 / 5$.

${ }^{70}$ Alston a Chamberlain. Report on Brazil for 1926. FO 371/11967, rolo 35.

${ }^{71}$ Alston a Chamberlain. Report on Brazil for 1926. FO 371/11967, rolo 35. 
ambições desmedidas" (Garcia, 2005: p. 140). Contudo, só foi possível adotar a estratégia "vencer ou não perder" (op. cit.), porque se sabia que os custos da confrontação e da retirada eram reduzidos: à Grã-Bretanha não convinha retaliar; a Alemanha entendia o veto como uma ação de protesto contra a Liga e não como uma ofensa ao país; e os EUA, principal parceiro comercial do Brasil, encontravam-se fora da $\mathrm{SdN}$, logo, eram indiferentes à radicalização da posição brasileira (Garcia, 2005).

O custo político da saída do Brasil mostraria-se pequeno dada a pouca longevidade da Liga pelo seu caráter demasiadamente eurocêntrico e pela sua incapacidade coercitiva. A saída não chegou a representar uma derrota para o país, sendo sua participação nas instâncias genebrinas onerosa e sem retorno pragmático. O fim abrupto da aventura genebrina deixou, contudo, resquício de frustração pelos anos de campanha que em nada resultaram. O comportamento brasileiro de opor-se aos acertos locarnistas, garantidores da paz e da segurança europeias, foi objeto de reprovação mundial e deixou sequelas na imagem internacional do país, que a sua retirada da Liga, mesmo com manifestações de pesar e pedidos de reconsideração, não logrou mitigar (Garcia, 2006).

A batalha de Genebra, segundo Seitenfus (1995), foi travada pela diplomacia brasileira com extrema incompetência. Melo Franco avaliou mal as chances de sucesso da demanda brasileira, confundindo a cordialidade presente nas relações interpessoais dos delegados diplomáticos com as suas políticas de Estado. A interpretação equivocada do tratamento recebido pelos representantes britânico e francês contribuiu para que o governo brasileiro magnificasse as demonstrações de apoio à campanha nacional (Santos, 1995). Quando Melo Franco percebeu a impossibilidade de concretização da demanda brasileira e o caráter danoso que teria o veto, foilhe impossível redirecionar a diretriz traçada pelo presidente e pelo chanceler. Bernardes ganhou duplamente, portanto, com a derrota brasileira na Liga: dirimiu o prestígio desfrutado por Melo Franco no âmbito nacional, que representava um concorrente em potencial a sua reeleição à Presidência da República, e angariou apoio interno, ao exibir-se como defensor do prestígio e do patriotismo brasileiros (Rodrigues, 1995).

$\mathrm{O}$ veto à entrada da Alemanha foi um elemento adicional de uma crise já existente entre as potências europeias sobre a forma como seriam implantados os acordos de Locarno. Apesar de o Brasil ter sido considerado o grande responsável pelo fracasso da Assembleia extraordinária 
de março de 1926 e ter sido objeto de críticas na impressa internacional, o veto não foi a causa da crise, que tinha origens e implicações mais profundas. Após seis meses de apaziguamento de ânimos e de busca por soluções conciliatórias, a Alemanha, finalmente, teve sua admissão na Liga e seu assento permanente no Conselho efetivados em setembro de 1926. A SdN, sob a liderança de Chamberlain, Briand e Stresemann, entrava, assim, "em fase de grandes expectativas em relação a seu poder de atuação internacional" que perduraria até a crise da Manchúria, em 1931 (Garcia, 2006: p. 423).

Apesar de não ter conseguido gerenciar, de forma sustentável, a ordem internacional, a Liga incorporou, em seu pacto, princípios importantes, especialmente para Estados menores. A aspiração à universalidade, que contemplava uma abertura à participação de todos os Estados independentes, representou avanço qualitativo em relação às conferências realizadas ad hoc e para as quais muitas pequenas nações sequer eram convidadas. $O$ fato de a $\mathrm{SdN}$ ser um fórum permanente propiciava aos Estados menores expressar suas opiniões e contribuir no debate e na condução das questões mundiais. Finalmente, o princípio da segurança coletiva, mesmo não tendo sido seguido, significava uma garantia quanto a possíveis abusos dos mais fortes contra os mais fracos (Watson, 2004).

A origem do insucesso da Liga pode ser atribuída ao problema de percepção entre as potências europeias que viam na Liga um sistema de congresso em que teriam a plena dominância e a crença dos países latino-americanos de construir uma ordem mais igualitária. A crise pode ter servido para demonstrar que a ideia de um organismo mundial como a Liga talvez fosse prematura, tendo em vista que as relações políticas internacionais eram dominantemente europeias. Como afirmou o historiador britânico Leuchars, "the 1926 crisis was perhaps the first sign that twentieth century ideas were moving too fast for nineteenth century minds, and that a new world order could not be created by a paper covenant, but only through bitter experience" (Leuchars, 2001: p. 140). 


\title{
CAPÍTULO 2
}

\section{A candidatura brasileira a um assento permanente no Conselho de Segurança da ONU}

\begin{abstract}
"Obviously, there are a group of countries determined to get permanent seats and are campaigning very much for that and there are others in the organization which are determined to prevent them from getting permanent seats."
\end{abstract}

$$
\text { Kofi Annan }{ }^{72}
$$

O tema da reforma do Conselho de Segurança tem sido objeto de debates desde a fundação da ONU. No início dos anos 1990, a superação da dinâmica da Guerra Fria, que implicava o boicote sistemático das atividades do Conselho, trouxe novo fôlego ao órgão. Isso redespertou o interesse dos Estados em discutir sua composição, suscitando a realização de conferências e a criação de grupos de trabalho, dedicados a elaborar modos de tornar o Conselho e o sistema onusiano mais eficientes e efetivos (Viotti, 2010).

O Conselho é um órgão de composição consideravelmente restrita mesmo após a reforma de 1963, que expandiu o número de integrantes de onze para quinze. A crítica mais contundente e reiterada feita ao diretório central das Nações Unidas refere-se, portanto, ao seu caráter exclusivista e antidemocrático, em que apenas poucos países possuem assentos, cinco dos quais de modo permanente e com poder de veto (Pureza, 2004; Viegas, 2008).

Outra censura comumente feita é quanto à falta de transparência nos processos de tomada de decisão, cujas discussões ocorrem, majoritariamente, fora de sessões formais. As ações do Conselho são frequentemente acusadas de ter viés de seletividade, double standards, sendo instrumentalizadas por interesses político-econômicos dos países membros, em especial os cinco permanentes. $\mathrm{O}$ fato de as ações do Conselho não serem sujeitas ao controle ou à revisão de nenhum outro órgão, porquanto inexiste na organicidade onusiana um sistema de freios e contrapesos análogo ao que rege as divisões de poder intraestatais, também suscita críticas dos países membros da $\mathrm{ONU}^{73}$.

\footnotetext{
${ }^{72}$ Artigo de Amit Baruah "India May Accept Security Council Seat without Veto," no jornal The Hindu, Disponível em: http://www.hindu.com/2004/12/19/stories/2004121907600100.htm. Acesso em: 19/01/2014.

${ }_{73}$ Disponível em: http://www.globalpolicy.org/security-council/security-council-reform/49885.html?itemid=1321. Acesso em: 22/02/2014.
} 
As críticas supracitadas e outras falhas do Conselho são abordadas nas propostas de reforma dos diferentes países e grupos regionais. Conquanto a necessidade de reformar o órgão seja comungada unanimemente pelos Estados, há divergência no tocante à forma que deverá ter o futuro Conselho reformado. As questões quanto à composição do órgão e ao poder de veto são as mais controversas e, por consequência, os principais impedimentos a avanços nas negociações. Tendo em vista este trabalho dedicar-se ao estudo da candidatura brasileira a um assento permanente, foram priorizados os elementos da reforma que interferem, diretamente, na proposição do Brasil, que são as discussões quanto à ampliação das cadeiras e à continuidade do poder de veto.

\subsection{O Brasil e a reforma do Conselho de Segurança da ONU}

O Brasil e o Japão são os países que, por mais vezes, ocuparam assentos não permanentes do Conselho, tendo sido eleitos para o órgão dez vezes cada um (Patriota, 2013). Este dado serve para ilustrar o elevado interesse do país pelas atividades da instância máxima onusiana responsável pela paz e pela segurança internacionais. O país, partícipe dinâmico e ativo de fóruns multilaterais, adota, tradicionalmente, posicionamentos que tendem a enfatizar a necessidade de inclusão de países periféricos, cuja expressão geopolítica possa ser projetada pelo mundo. A defesa de um Conselho ampliado que melhor represente Estados em desenvolvimento esteve, portanto, reiteradamente presente nos discursos brasileiros, desde o nascimento da ONU. Em 1989, o então presidente da República, José Sarney, perante a $44^{\mathrm{a}}$ AGNU, defendeu "o alargamento da composição do Conselho de Segurança, com vista a uma participação mais efetiva dos países periféricos" (Arraes, 2005: p. 5).

A primeira iniciativa de discutir a reforma do Conselho, após a renovação de suas atividades, com o fim do imobilismo atávico da Guerra Fria, foi a Resolução 47/62 da Assembleia Geral, adotada em 11 de dezembro de 1992. Intitulada Question of equitable representation on and increase of the membership of the Security Council ${ }^{74}$, recomendava aos países mandar comentários ao secretário-geral sobre a possível revisão do Conselho. Setenta e

\footnotetext{
${ }^{74}$ UNITED NATIONS. General Assembly. A/48/264. 20 jul. 1993. Disponível em: http://dcuments-dds-y-un.org. Acesso em: 25/12/2013.
} 
nove países atenderam a solicitação e enviaram suas posições sobre o tema, inclusive entidades regionais, como a Organização da Unidade Africana (OUA).

O comentário enviado pelo Brasil sugeria a ampliação do Conselho em quatro membros permanentes adicionais, que seriam assim divididos: "two additional major industrialized States, as well as one major country from each of the main regions of the developing world"75. A quantidade de novos membros temporários não foi explicitada, mas subentende-se que seriam três ou quatro, tendo em vista o documento brasileiro indicar o total de 23 ou 24 membros para o órgão. O Brasil não sinalizou sua candidatura naquele momento, contudo percebe-se que os elementos principais do posicionamento brasileiro permaneceram inalterados até os dias atuais.

Após o recebimento dos comentários dos Estados-membros, a Assembleia Geral adotou a Resolução 48/26, em 3 de dezembro de 1993, que formou um grupo de trabalho para examinar a composição do Conselho de Segurança e as questões relativas ao seu método de trabalho e ao seu funcionamento $^{76}$. O grupo vigoraria durante anos e, apesar de auxiliar a esclarecer as posições dos Estados a respeito da reforma, não chegaria a nenhuma conclusão como indicaria seu relatório:

While there was a convergence of views that the membership of the Security Council should be enlarged, there was also agreement that the scope and nature of such enlargement required further discussion. ${ }^{77}$

Em setembro de 1994, durante o governo do presidente Itamar Franco, o Brasil formalizou suas pretensões acerca da reforma. A candidatura foi lançada pelo então chanceler Celso Amorim, considerado um dos seus principais idealizadores ${ }^{78}$. O discurso responsável por tornar pública e oficial essa ambição foi proferido, na $49^{\mathrm{a}}$ Assembleia Geral, pelo próprio chanceler. A candidatura esteve vigente apenas durante os últimos três meses da gestão de Itamar Franco, tendo sido iniciada dias antes de o então ministro da Fazenda, Fernando Henrique Cardoso, eleger-se no primeiro turno das eleições presidenciais, em novembro de 1994 . O foco

75 UNITED NATIONS. General Assembly. A/48/264. 20 jul. 1993. Disponível em: http://documents-ddsny.un.org/doc/UNDOC/GEN/N93/396/96/img/N9339696.pdf?OpenElement. Acesso em: 25/12/2013.

${ }^{76}$ Open-Ended Working Group on the Question of Equitable Representation on and Increase in the Membership Of The Security Council And Other Matters Related To The Security Council - OEWG.

77 UNITED NATIONS. General Assembly. A/50/47. 13 set. 1996. Disponível em: http://documents-ddsny.un.org/doc/UNDOC/GEN/N96/240/70/pdf/N9624070.pdf?OpenElement. Acesso em: 28/12/2013.

78 "Trata-se de um tema caro ao ministro Celso Amorim, que trabalhou durante muito tempo em assuntos multilaterais e em questões de segurança internacional e que encontrou a simpatia e o interesse do presidente e de amplos setores na diplomacia, nas Forças Armadas e nos grupos de apoio dentro e fora do PT." (Almeida apud. Brigido, 2010: p. 168) 
deste estudo, portanto, se concentrou nas gestões dos governos posteriores, pois foram os responsáveis por dar substrato à candidatura, desenvolvendo-a, com maior ou menor ênfase, ao longo dos anos.

A pretensão brasileira, vigente até os dias atuais, teve seu ápice no governo Lula e, embora de "forma subterrânea"79, manteve-se presente na política externa da presidenta Dilma Rousseff. Por estar a gestão da presidenta em curso e por sua história ser demasiadamente recente, o recorte temporal deste trabalho termina em 2010, não abrangendo o atual governo. Assim, para entender as diferenças e as particularidades existentes na condução da candidatura brasileira neste período de 16 anos, de 1994 a 2010, foi preciso desmembrá-lo, por ser historicamente longo e envolver alterações significativas dentro e fora do país.

\subsection{O início do governo de Fernando Henrique Cardoso}

O primeiro ano de governo FHC coincidiu com a comemoração do cinquentenário das Nações Unidas. Este fato influenciou o pronunciamento do ministro de Estado das Relações Exteriores na abertura da AGNU, em setembro de 1995, que se destinou a tratar da história, dos desafios e das possibilidades da Organização. Isso foi evidenciado pelo fato de Lampreia ter-se referido às Nações Unidas 36 vezes, sendo essa a segunda maior frequência registrada nos 16 anos analisados.

A reforma do sistema onusiano, em especial do Conselho de Segurança, foi considerada "um imperativo que não mais deve ser postergado" (Corrêa, 2011: p. 724). A preeminência da reforma ficou evidente pelas quinze ocorrências dessa temática no pronunciamento. $\mathrm{O}$ argumento no qual se baseou o chanceler para justificar a urgência gravitou em torno da representatividade necessária para dotar o CSNU de "legitimidade inquestionável"; de composição "mais equilibrada e que reflita melhor a diversidade de visões de mundo"; de "maior autoridade e eficiência" (op. cit., p. 725).

A reforma sugerida visava à ampliação tanto dos membros permanentes quanto dos temporários. Apesar de não explicitar quantas vagas deveriam ser criadas nem de mencionar o

\footnotetext{
${ }^{79}$ Expressão usada pelo então assessor da presidenta Dilma para assuntos internacionais, o embaixador Guilherme de Aguiar Patriota. Disponível em:

http://operamundi.uol.com.br/conteudo/noticias/30071/brasil +muda+estrategia + por + vaga + permanente + no $=$ conselho + de+seguranca+da+ONU.shtml. Acesso em: 02/07/2014.
} 
Brasil como candidato, Lampreia enunciou que "países em desenvolvimento com projeção global (...) devem estar presentes no núcleo de membros permanentes" (op. cit., p. 725). Apesar de sua alocução dar margem a interpretações de que o país almejava um assento permanente, Lampreia, em publicação dedicada à compilação de seus discursos, foi de encontro a isso na abertura da $50^{\mathrm{a}}$ sessão da AGNU:

Aqui, tínhamos um problema: havia-se firmado, na opinião pública brasileira, a ideia de que éramos candidatos a uma vaga permanente no Conselho, como estávamos em uma campanha que subordinava todas as demais vertentes da politica externa brasileira a esse objetivo. Nada mais falso. O discurso era, portanto, uma oportunidade de "baixar essa bola", colocando o assunto na perspectiva correta, ou seja, o Brasil defende uma reforma do Conselho que o torne mais eficaz, ao aumentar a sua legitimidade, o que se consegue através do aumento da sua representatividade. Se a consequência de tal reforma seria ou não o ingresso do Brasil, isso era uma questão que ficaria para depois; bastava que nós mostrássemos um empenho real em ajudar a fazer uma boa reforma e que nos dispuséssemos a aceitar uma convocação da comunidade internacional caso ela fosse julgada útil e oportuna. (Lampreia, 1999: p. 333)

No mês seguinte à sua alocução na AGNU, em outubro de 1995, diante da repercussão interna a respeito de que o Brasil desejava ocupar uma vaga permanente, Lampreia publicou artigo no jornal $O$ Estado de São Paulo, em que, novamente, buscou desfazer a suposta candidatura brasileira. O ministro elencou dez "pontos básicos" do posicionamento brasileiro sobre o tema, entre os quais, o de que o país "não tem obsessão com o assunto, nem subordina ou condiciona qualquer dos seus objetivos e áreas de ação da política externa à obtenção de uma vaga permanente no CSNU ou ao apoio a essa aspiração" ${ }^{80}$. Distanciava-se, deste modo, a política externa de Lampreia da realizada por seu antecessor, Amorim (Brigido, 2010).

Além do tema da celebração do quinquagésimo aniversário da Organização, outros acontecimentos de destaque daquele ano marcaram a alocução do ministro Lampreia. No que diz respeito ao contexto interno, a recém-lograda estabilidade econômica, decorrente da implantação do Plano Real, aliada à consolidação democrática, auferida por meio das reformas constitucionais, auxiliou a renovação da imagem do Brasil, que se tornou, novamente, destino preferencial de recursos e investimentos externos (Corrêa, 2011).

\footnotetext{
${ }^{80}$ LAMPREIA, Luiz Felipe. "O Brasil e a reforma das Nações Unidas". O Estado de São Paulo. Espaço Aberto, 21/10/1995. Barreto, 2012: p. 290; Brigido, 2010: p. 131.
} 
O chanceler analisou a conjuntura internacional, avaliando o que ele identificava como tendências positivas - fim da guerra fria, solução de diversos conflitos regionais, abertura e crescimento - e negativas, como a persistência da pobreza e da violência, bem como da instabilidade econômica provocada pela especulação e pela volatilidade dos capitais. (Silva, 2009: p. 2)

No ano seguinte, em 1996, o presidente Cardoso ponderou, em duas ocasiões - durante visita presidencial a Nova Delhi, em janeiro, e em audiência com o secretário-geral da ONU, em fevereiro - que a prioridade brasileira era a democratização das Nações Unidas e não a conquista de um assento permanente em seu Conselho. A participação mais ativa na arena internacional reivindicada por países emergentes, como o Brasil e a Índia, não precisaria, necessariamente, ocorrer, segundo Cardoso, no âmbito do Conselho de Segurança (Arraes, 2005; Brigido, 2010).

Lampreia voltou a representar o Brasil na $51^{\text {a }}$ sessão da AGNU, ocorrida em 23 de setembro de 1996, e a proferir seu discurso de abertura. O pronunciamento apontou para a ameaça de a organização tornar-se anacrônica e alegou que as Nações Unidas se encontravam "diante de uma encruzilhada" (Correa, 2011: p. 727), tendo em vista as novas configurações das forças mundiais e os seus desdobramentos. Uma percepção eminentemente pessimista foi esboçada para a organização que passava por grave crise financeira e motivacional, como demonstra o trecho:

Temos de corrigir a tendência a produzir reuniões cujo único resultado é gerar novas reuniões ou resoluções de sentido retórico. Temos de acabar com a imagem de uma ONU morosa, letárgica e incapaz de corresponder aos desafios dos tempos. (op. cit., p. 741)

$\mathrm{O}$ endividamento da organização estava a ponto de comprometer sua eficiência e o adequado desempenho de suas funções, ameaçando-a de perder espaço para outras entidades e organismos. Diante desse quadro, a solução indicada por Lampreia seria a de reformar as Nações Unidas, fundamentando-se nos seguintes elementos: possibilitar à ONU ser um contraponto ao unilateralismo e às "políticas de poder"; provê-la de "capacidade de atuação no mundo", que não é mais como o da época de sua criação; e devolver-lhe a "condição de foro privilegiado do debate e da ação político-diplomática" (op. cit., p. 741).

O embaixador defendeu, igualmente, a reforma do Conselho, que deveria ser ampliado, para possibilitar "maior participação de países com capacidade de atuação global e disposição de 
arcar com as responsabilidades daí decorrentes" (op. cit., p. 742). Em seguida, Lampreia discorreu sobre as aspirações brasileiras de expandir sua atuação nos foros decisórios internacionais, apresentando as credenciais brasileiras, que se baseavam na dimensão da democracia; na economia diversificada e dinâmica; no imenso potencial do mercado interno; na capacidade de atrair investimentos produtivos; na força que o país representava em favor da paz e da integração; na diversidade étnica interna (multiculturalismo); e no fato de o Brasil ser líder em desarmamento, o que mereceu sete menções ao longo do pronunciamento.

Percebe-se, dessa forma, que o discurso de Lampreia perante a tribuna da ONU deu margens a inferências no sentido de que o país tinha a aspiração de ocupar espaço prominente na arena global, qual seja, um assento permanente no Conselho, o que caracterizaria uma candidatura velada do país. Na mesma época, contudo, ao comentar a ausência de avanços na agenda de reforma, Lampreia afirmou que o assunto Conselho de Segurança estava "mais parado do que o trânsito na $1^{\text {a }}$ Avenida", e que a inclusão do Brasil não era prioridade para o governo Cardoso (Lampreia apud. Arraes, 2005: p. 9).

\subsection{A reforma ganha impulso}

No ano de 1997, várias iniciativas conferiram momentum à agenda da reforma. A eleição do diplomata ganense Kofi Annan para secretário-geral das Nações Unidas contribuiu para dar novo fôlego aos debates. Determinado a conseguir reforma pragmática e realista da Organização, Annan introduziu o projeto Renewing the United Nations: A Programme for Reform na Assembleia Geral, em 14 de julho, apenas seis meses depois de ter sido nomeado. A iniciativa procurava dotar a ONU de maior eficiência e melhorar sua capacidade de gerenciamento ${ }^{81}$. O presidente da $51^{\text {a }}$ Assembleia, Ismail Razali, também apresentou projeto de reforma do Conselho, o qual previa ampliação dos membros permanentes e dos temporários. Outro fator que deu impulso à agenda foi o anúncio dos EUA de flexibilizar seu posicionamento tradicional, para favorecer não só o acréscimo da Alemanha e do Japão, mas também o de três países em

\footnotetext{
${ }^{81}$ Não abordava, contudo, a questão mais sensível de ampliar a composição do CSNU, o que seria sugerido somente em plano de reestruturação mais abrangente, em 2005.
} 
desenvolvimento no $\mathrm{CSNU}^{82}$.

Nesse contexto, a Assembleia de Chefes de Estado da Organização da Unidade Africana (OUA), em sua 33 ${ }^{a}$ Sessão Ordinária, em junho de 1997, elaborou a Declaração de Harare, que nortearia o posicionamento do continente sobre a reforma do Conselho por quase uma década. $\mathrm{O}$ documento, encaminhado à ONU pelo Zimbábue, defendia a ampliação do CSNU para 26 membros, destinando-se à África dois assentos permanentes e cinco assentos não permanentes. A distribuição das cadeiras seria feita de acordo com critérios estabelecidos pelos africanos, em um sistema de rotação estabelecido pela OUA. Aos novos membros permanentes deveriam ser concedidas as mesmas prerrogativas dos antigos. Havia, entretanto, uma contradição na proposta africana, que sugeria os membros permanentes fossem, na verdade, eleitos por períodos determinados:

Ultimately, the permanent members should also be nominated by their respective regions and elected by the General Assembly. Such a system of periodic elections of permanent members of the Security Council, will in the final analysis ensure that the decisions of the Council are less subject to the strictly national interests of its various members, ${ }^{83}$

Outros países manifestaram-se a respeito do efervescente debate sobre a reforma da ONU. O então presidente da Argentina, Carlos Menem, em entrevista publicada pelo jornal $O$ Estado de São Paulo, em agosto, afirmou que o país era contrário à eventual indicação do Brasil a membro permanente e que a candidatura brasileira ao cargo quebraria o equilíbrio regional (Amorim, 2003). A declaração teve ampla repercussão na imprensa e acarretou forte reação negativa do presidente Fernando Henrique Cardoso, que a teria recebido com "surpresa e desagrado" ${ }^{84}$. Para amenizar a celeuma, o ministro das Relações Exteriores argentino, Guido Di Tella, explicou não ser a intenção de seu país vetar o Brasil e que, para ele, a indicação do vizinho tampouco seria uma tragédia: "Não queremos, não podemos e não vamos vetar o Brasil para o Conselho de Segurança da ONU. Isto não é uma questão de vida ou morte. Temos

\footnotetext{
${ }^{82}$ LAMPREIA, Luiz Felipe. A reforma do Conselho de Segurança. Folha de São Paulo. Opinião. 31/08/1997. Disponível em: www1.folha.uol.com.br/fsp/1997/8/31/opinião/8.html. Acesso em: 28/08/2014.

83 Harare Declaration of the Assembly of Heads of State and Government of the Organization of African Unity on the Reform of the United Nations Security Council. 04 jun. 1997. Disponível em http://www.globalpolicy.org/component/content/article/200/41390.html Acesso em: 31/12/2013..

${ }_{84}$ DI TELLA, Guido. Menem recua sobre veto ao Brasil na ONU. Folha de São Paulo. Artigo. 20/08/1997. Disponível em: www1.folha.uol.com.br/fsp/brasil/fc200808.htm. Acesso em: 20/08/2014.
} 
algumas opiniões diferentes, que serão discutidas cordialmente" ${ }^{85}$.

Lampreia também se posicionou a respeito da controvérsia com o país platino, em artigo publicado no jornal Folha de São Paulo. O ministro minimizou a polêmica, ao afirmar que as diferenças de enfoque e política entre os dois países não eram apenas "naturais, mas saudáveis" e que a reforma do Conselho não era um tema "central, estrutural nas relações entre o Brasil e a Argentina ou para o Mercosul". O interesse principal do Brasil era, segundo o ministro, preservar a relação com o vizinho e a coesão do bloco regional sul-americano, evitando que o tema da reforma fosse instrumentalizado para gerar atritos entre os parceiros ou criar elementos de barganha nas negociações com o Brasil ${ }^{86}$.

Em setembro, o embaixador da Malásia, Ismail Razali, aproveitando-se de subsídios do grupo de trabalho para examinar a composição do Conselho de Segurança e as questões relativas ao seu método e ao seu funcionamento, apresentou formalmente sua proposta de reforma na Assembleia. O projeto previa a ampliação do Conselho para 24 membros com a criação de cinco assentos permanentes, sem direito a veto, que seriam assim distribuídos: três cadeiras para países em desenvolvimento da África, da Ásia e da América Latina e Caribe; e duas para países desenvolvidos. Os assentos não permanentes seriam aumentados em quatro e distribuídos um para cada região: África, Ásia, Europa Oriental e América Latina. A proposta previa, ademais, a limitação do uso do veto pelos membros atuais do CSNU.

Aproveitando-se dos debates no âmbito do grupo de trabalho e impulsionado pelas proposições de Annan, de Razali e da OUA, Lampreia pormenorizou o tema da reforma e da proposta brasileira. Esse foi o discurso em que o assunto foi mais amplamente elaborado de todos os dezesseis anos analisados. O pronunciamento assinalou os problemas enfrentados pela Organização que comprometiam sua eficácia na promoção da paz, da cooperação e do desenvolvimento: inação, incapacidade de gerar consensos, obstrucionismo e excessiva politização. O ministro clamou pela reforma tornada "inadiável" e preconizou que ela compreendesse mudanças não apenas na estrutura da Organização, mas também nos temas e conteúdos trabalhados no âmbito das Nações Unidas (Correa, 2012: p. 757-758).

\footnotetext{
${ }^{85}$ DI TELLA, Guido. Menem recua sobre veto ao Brasil na ONU. Folha de São Paulo. Artigo. 20/08/1997. Disponível em: www1.folha.uol.com.br/fsp/brasil/fc200808.htm. Acesso em: 20/08/2014.

${ }^{86}$ LAMPREIA, Luiz Felipe. A reforma do Conselho de Segurança. Folha de São Paulo. Opinião. 31/08/1997. Disponível em: www1.folha.uol.com.br/fsp/1997/8/31/opinião/8.html. Acesso em: 28/08/2014.
} 
No que se refere ao Conselho, o representante brasileiro ressaltou a necessidade de conferir-lhe maior representatividade. Lampreia defendeu a ampliação dos assentos permanentes e dos rotativos para que ambos contemplassem a representação de países em desenvolvimento. $\mathrm{O}$ chanceler rechaçou a criação de novas categorias de membros, pois ocasionariam o esvaziamento do poder dos futuros integrantes, enfraquecendo a participação da América Latina num Conselho ampliado. Defendeu que a escolha dos novos membros deveria ser feita de forma democrática: "a identificação dos novos membros permanentes deve ser um exercício de realismo e pragmatismo, a partir de um processo democrático de seleção" (Lampreia, 1999: p. 368-369).

O trecho em que Lampreia mencionou o Brasil já se manifestar "pronto a aceitar as responsabilidades decorrentes da condição de membro permanente do Conselho de Segurança, se a isso for chamado pela comunidade internacional" demonstra que, mesmo negando que estivesse fazendo uma campanha em prol de um assento, o país mostrava-se disposto a arcar com tal encargo caso fosse escolhido. O ministro afirmou que, se escolhido, o Brasil ocuparia o assento em representação à América Latina e ao Caribe (Lampreia, 1997), o que poderia ser considerado indício do emprego do argumento da representação regional. Faz-se necessário ressaltar, contudo, que o discurso se inseria no contexto de debates suscitados, inter alia, pelo projeto Razali, o qual previa a criação de um assento permanente destinado à América Latina e ao Caribe. Conforme será pormenorizado no capítulo 3, a menção de ocupar o assento em representação à região referiu-se, especificamente, à proposta de Razali e não representou uma argumentação consistente da gestão de Lampreia à frente do Itamaraty.

$\mathrm{O}$ último ano do primeiro mandato de Cardoso foi fortemente influenciado pelo contexto de agravamento da crise asiática. Flutuações monetárias iniciadas em 1997, na Tailândia, alastraram-se pelos países da região, contaminando o sistema financeiro da Rússia e, em efeito dominó, o da América Latina. A crise alcançou o Brasil em 1998, causando forte pressão sobre a moeda e as reservas nacionais.

O Brasil foi novamente representado por Lampreia na $53^{\mathrm{a}}$ sessão da AGNU, em que proferiu o discurso inaugural em 21 de setembro de 1998. Quanto ao tema da reforma da ONU, o ministro reiterou a posição brasileira de que o CSNU devia ser ampliado "nas duas categorias de membros, com a presença, em ambas, de países em desenvolvimento" (Correa, 2012: p. 774). Os argumentos empregados para validar a demanda pela reforma foram semelhantes aos 
mencionados na alocução da $50^{\text {a }}$ sessão, de setembro de 1995, e basearam-se na necessidade de aumentar a legitimidade, a representatividade e a eficácia do Conselho.

Em seu pronunciamento, o embaixador mencionou as credenciais do Brasil para "desempenhar papel mais ativo na construção de uma ordem mundial que favoreça a realização da paz e do desenvolvimento" (Corrêa, 2012: p. 770): valor relativo do país; histórico de seu comportamento internacional; amadurecimento da democracia; modernização da economia. Pode-se inferir que essas credenciais serviriam, igualmente, para legitimar a aspiração brasileira ao CSNU, tendo em vista que a atuação do Brasil no órgão restrito das Nações Unidas ia na direção de promover objetivos análogos.

\subsection{A crise e a ambição brasileira}

Em 1999, o contexto interno era caracterizado pela desvalorização do real em razão da crise especulativa, e o âmbito mundial, pela incapacidade da ONU de resolver as crises dos Bálcãs, do Timor Leste e de Angola. O tema da reforma do Conselho havia perdido espaço na agenda internacional, tendo em vista a incapacidade de chegar-se a um consenso e o desgaste das discussões, que, no biênio 1999-2000, haviam perdido momentum. Assim, o pronunciamento de Lampreia, na abertura da $54^{\mathrm{a}}$ sessão da AGNU, incitou, apenas de forma vaga, a temática da reforma, exortando o "caminho da renovação, da mudança" para que a Organização seja "forte e eficaz" (op. cit., p. 790). O padrão esboçado nos anos anteriores foi rompido, tendo em vista a alocução não explicitar a reforma da instância máxima responsável pela paz e pela segurança mundiais.

Em 2000, o impacto da instabilidade financeira global, que ocasionou um processo repentino de enfraquecimento da moeda brasileira, persistia. Diante dos problemas econômicos internos, Lampreia comentou que o projeto "Brasil potência mundial" estava arquivado, porquanto era preciso que o país tivesse poder militar, o que significava dispor de capacidade de atuação militar em conflitos fora da fronteira. Segundo o chanceler, o Brasil, com os desafios sociais que tinha, não podia gastar recursos para criar tal poderio (Lampreia, apud. Arraes, 2005).

O ponto de inflexão da nova postura do governo Cardoso em relação à meta de alcançar 
um espaço de maior destaque na cena mundial ocorreu em agosto quando o embaixador dos EUA junto às Nações Unidas, Richard Holbrooke, em visita ao Brasil, incitou o país a aumentar sua participação em missões de paz, o que, para ele, podeira reforçar as credenciais brasileiras para o pleito de ocupar um assento permanente no Conselho. A resposta alegaria "a falta de recursos financeiros e a visão de que a reforma do Conselho estaria realmente fora das preocupações principais das grandes potências" (Arraes, 2005: p. 14).

Em setembro, Lampreia proferiu seu sexto e último discurso como representante brasileiro na sessão de abertura da $55^{\mathrm{a}}$ AGNU. Conforme avalia o embaixador Seixas Corrêa, a alocução "caracterizou-se por especial viés analítico. Iniciava-se o novo milênio, momento "de avaliação e de renovação de expectativas" (Corrêa, 2012: p. 793). A realização da Cúpula do Milênio, o fracasso da Conferência Geral da Organização Mundial de Comércio (OMC), em Seattle, e a iniciativa brasileira de sediar a I Reunião de Presidentes da América do Sul foram alguns acontecimentos que compunham o contexto da virada do século. O balanço realizado pelo chanceler em sua fala, todavia, não mencionou a reforma da ONU - episódio inédito na gestão do governo FHC até então - nem do seu Conselho, o que também havia ocorrido no ano anterior.

O ano de 2001 caracterizou-se por extrema conturbação internacional. Os atentados de 11 de setembro ao World Trade Center e ao Pentágono causaram o adiamento da abertura dos trabalhos da Assembleia Geral e levaram o terrorismo a ser o principal tema das sessões, iniciadas apenas em novembro. No contexto regional, a crise econômica argentina causou desgastes nas relações bilaterais com o Brasil, acarretando consequências negativas para o Mercosul. A situação das negociações comerciais da OMC, paralisadas desde o fiasco de Seattle, contribuíam com o clima de preocupação e incerteza, que melhoraria com o início da "Rodada do Desenvolvimento", em novembro, na Conferência de Doha.

A seriedade do quadro de instabilidade política mundial levou o presidente a realizar o discurso do Brasil na 56 ${ }^{\mathrm{a}}$ sessão de abertura da AGNU, em 10 de novembro. Foi a primeira vez que Cardoso fez o pronunciamento pessoalmente, já estando no seu sétimo ano como chefe do Estado brasileiro. O tema da reforma da ONU foi retomado com a exortação do presidente para que o Conselho contemplasse, entre seus membros permanentes, "países em desenvolvimento com credenciais para exercer as responsabilidades que a eles impõe o mundo de hoje" (Corrêa, 2012: p. 820). O apelo à candidatura velada do Brasil a um assento permanente foi fundamentada 
com um argumento reiterado em inúmeras ocorrências: o da representatividade. Ao defender que o Conselho não podia permanecer com uma composição que refletia "o arranjo entre os vencedores de um conflito ocorrido há mais de 50 anos" (op. cit., p. 820), Cardoso aproveitou para lançar uma credencial inédita: a participação de soldados brasileiros na II Guerra Mundial.

Em 2002, último ano do governo de Fernando Henrique Cardoso, o tema da reforma do Conselho voltou a ser mencionado em diversas alocuções governamentais e em visitas oficiais (Brigido, 2010: p. 152). O período foi marcado por conturbações no Oriente Médio, com os EUA preparando-se para a Guerra do Iraque, que teria início no ano seguinte. O contexto interno caracterizava-se pela instabilidade em torno da eleição do presidente Luiz Inácio Lula da Silva, que "assustou" os mercados, levando à fuga de capitais e à pressão sobre a moeda (Corrêa, 2012). Perante a $57^{\mathrm{a}}$ sessão ordinária da AGNU, em 12 de setembro, Celso Lafer, que sucedeu Lampreia como ministro das Relações Exteriores, recebeu o encargo de proferir o último discurso da gestão.

No que se refere à questão da reforma do CSNU, a alocução de Lafer manteve-se fiel à linha desenvolvida até então. Voltou a exortar a ampliação dos assentos permanentes e temporários do Conselho, fundamentando-se no imperativo de "aumentar sua legitimidade e criar bases mais sólidas para a cooperação internacional". A candidatura do Brasil foi sugerida na afirmação de que o país "está pronto a dar sua contribuição para o trabalho do Conselho de Segurança e a assumir todas as suas responsabilidades" (op. cit., p. 831).

\subsection{O início do governo Lula}

Lula já fazia menções à reforma do Conselho de Segurança como um tema "essencial" da agenda internacional desde antes de assumir o governo, como comprova seu discurso realizado no National Press Club em Washigton, em dezembro de 2002 (Brigido, 2010: p. 167). Em sua alocução de posse, o presidente defendeu tornar o órgão mais "representativo da realidade contemporânea, com países desenvolvidos e em desenvolvimento das varias regiões do mundo entre os seus membros permanentes" 87 .

A escolha de Celso Amorim para liderar o Itamaraty contribuiu para que a agenda da

\footnotetext{
${ }^{87}$ SILVA, Luiz Inácio Lula. Sessão solene de posse no Congresso Nacional. Brasília, 01/01/2003. Disponível em: file:///Users/coelhonatalia/Downloads/posse\%20lula\%202003.pdf. Acesso em: 23/08/2014.
} 
reforma do Conselho ganhasse destaque na gestão de Lula. O embaixador, que chefiou a Missão do Brasil junto à ONU, em Nova York, de 1995 a 1999, é considerado um dos principais, senão o principal formulador e articulador do pleito nacional. Dessa forma, assim como ocorreu na década de 1920, em relação à candidatura a um assento no Conselho da Liga das Nações, com a dupla Bernardes e Pacheco, a combinação Lula e Amorim no comando das relações externas do país conferiu novo ímpeto às ações brasileiras em prol de um assento permanente no CSNU.

As conjunturas internacionais do primeiro mandato de Lula contribuíam para que o tema voltasse a ser amplamente discutido pela opinião pública mundial. A incapacidade do Conselho de resolver a questão do Iraque, em 2003, representou um turning point na percepção da relevância de que dispunha as Nações Unidas no gerenciamento de crises mundiais. A invasão para destituir Saddam Hussein, acusado de desenvolver arsenal de destruição em massa, por coligação liderada pelos norte-americanos, sem o aval da ONU, conferiu, novamente, premência à agenda da reforma, como atestou Kofi Annan:

A arquitetura da governança global foi posta à prova até seu ponto de ruptura. Fosse qual fosse a agenda do governo dos Estados Unidos - ou as verdadeiras origens da Guerra do Iraque -, uma coisa ficou clara para todos nós: carecíamos de uma nova visão de segurança e do papel que as Nações Unidas deveriam desempenhar para obtê-la. Na crise, vi uma oportunidade e a necessidade de uma reforma. (Annan, 2013: p. 175)

Em resposta à profunda crise que a Segunda Guerra do Golfo desencadeou nas Nações Unidas, o secretário-geral da Organização anunciou, na $58^{\mathrm{a}}$ Assembleia Geral, em setembro de 2003, a criação do "Painel de Alto Nível sobre Ameaças, Desafios e Mudanças". Formado por dezesseis pessoas eminentes, representantes de ampla gama de experiências e expertises em organizações internacionais de países distintos, o High Level Panel (HLP) tinha a incumbência de mapear os desafios e os problemas comuns de segurança internacional enfrentados pelos Estados membros e recomendar medidas claras e práticas para a ação coletiva eficaz (Menezes, 2010).

Lula proferiu seu primeiro discurso como presidente do Brasil perante a AGNU, no dia 23 daquele mês. Seguindo o impulso de Annan, deu ênfase ao tema da reforma da ONU, além de remeter-se a outros acontecimentos internacionais importantes daquele ano, como a morte de Sergio Vieira de Melo e a denúncia do Tratado de Não Proliferação (TNP) pela Coreia do Norte. O apelo de Lula à reforma das Nações Unidas não se realizou em bases distantes das usadas por 
seu antecessor. A interpelação ao "risco de retrocesso no ordenamento político internacional" e à necessidade de dotar o CSNU de "instrumentos eficazes de ação" e de legitimidade assemelhamse aos argumentos do governo de FHC (Corrêa, 2012: p. 841). As cadeiras permanentes do Conselho deveriam ser expandidas de modo a refletir:

As mudanças que se processaram no mundo, sobretudo a emergência de países em desenvolvimento como atores importantes muitas vezes exercendo papel crucial na busca no cenário internacional de soluções pacíficas e equilibradas para conflitos. (Corrêa, 2012: p. 841)

No trecho supracitado, embora não tenha sido delineada uma proposta clara quanto ao formato desejado para a composição do Conselho, defenderam-se, tacitamente, as credenciais do Brasil para ocupar a futura vaga, mantendo o padrão discursivo do governo anterior. $\mathrm{Na}$ sequência, Lula afirmou que o Brasil estava pronto a dar a sua contribuição, deixando transparecer, assim, a intenção do país de ocupar um dos vindouros assentos do Conselho, elemento frequentemente reiterado em discursos.

Ao declarar que o Brasil estaria pronto para "refletir as percepções e os anseios de um continente que hoje se distingue pela convivência harmoniosa e constitui um fator de estabilidade mundial", Lula deixou entrever a possibilidade de o país vir a ser o representante da América Latina no CSNU. O presidente agradeceu o apoio recebido na América do Sul, que o incentivava a persistir na defesa de um Conselho "adequado à realidade contemporânea" (Corrêa, 2012: p. 841). Isso corroboraria a percepção de que o presidente se utilizou do argumento regional para legitimar o pleito nacional, tema que será pormenorizado no capítulo 3 .

\subsection{O momentum da reforma}

No biênio 2004-2005, o tema da reforma adquiriu grande destaque na agenda internacional e na atuação da diplomacia brasileira (Amorim, 2011). Em setembro de 2004, durante as sessões da 59 a ANU, ocorreu o lançamento oficial do Grupo dos Quatro (G-4), firmando a aliança entre Brasil, Índia, Japão e Alemanha, com o objetivo de promover a articulação conjunta das suas candidaturas a membros permanentes do CSNU. A ausência de um país africano no grupo deveu-se ao fato de os representantes do G-4 não vislumbrarem, com clareza, quais seriam os países africanos que melhor preencheriam as cadeiras reservadas ao 
continente. Dessa maneira, "o grupo optou por, simplesmente, apoiar a presença africana permanente no Conselho e esperar que surgisse um consenso regional sobre quais seriam os candidatos" (Vargas, 2009: p. 46).

O pronunciamento do presidente Lula na AGNU, naquele ano, defendeu uma reforma do Conselho que contemplasse a ampliação dos seus membros permanentes, de modo que estivesse adequado à realidade contemporânea e que não perpetuasse "aquela do pós-Segunda Guerra ou da Guerra Fria" (Corrêa, 2012: p. 859). Embora a alocução não tenha explicitado a candidatura, a formação do G-4 e a colaboração do embaixador João Clemente Baena Soares com o Painel de Alto Nível sobre Ameaças, Desafios e Mudanças demonstram a intensa movimentação da diplomacia em prol da aspiração do Brasil.

Em dezembro, após ardentes debates, o Painel de Alto Nível apresentou seu relatório final com 101 recomendações intitulado: "Um mundo mais seguro: nossa responsabilidade comum" (A/59/565) ${ }^{88}$. Embora não se destinasse, exclusivamente, a isso, o mandato do painel previa que se revisasse a atuação dos principais órgãos das Nações Unidas. Conquanto a ampliação do Conselho de Segurança tenha sido considerada uma necessidade pelos membros do painel, não se logrou chegar a um consenso em torno de uma proposta de reforma. Tampouco foi possível fazer recomendações quanto ao direito de veto dos membros permanentes do Conselho. Diante da pressão do representante russo, Evgeny Primakov, de não alterar a prerrogativa do veto, o painel limitou-se a reconhecer que o dispositivo era anacrônico e que seu uso deveria limitar-se a matérias vitais (Soares, 2009).

O ano de 2005 representou grande momento para a reforma, com a celebração do $60^{\circ}$ aniversário da Organização e a realização da Cúpula Mundial, que deram novo impulso às discussões, mobilizando as diplomacias de todo o mundo na formação de grupos políticos e na apresentação de propostas (Alves, 2008). Em março, Kofi Annan divulgou seu relatório "In Larger Freedom: towards security, development and human rights for all” (A/59/2005), no qual endossava os modelos de reforma propostos pelo Painel de Alto Nível e urgia os Estados a votar a reforma aproveitando-se daquele "historic turning point" (Weiss, 2009: p.2; Brigido: p. 176).

\footnotetext{
${ }^{88}$ UNITED NATIONS. A more secure world: our shared responsibility. Report of the High-level Panel on Threats, Challenges and Change. A/59/565. 01dez. 2004. Disponível em: http://daccess-ddsny.un.org/doc/UNDOC/GEN/N04/602/31/PDF/N0460231.pdf?OpenElement. Acesso em: 25/12/2013. Soares, 2005: p. 41; Freiesleben, 2013: p. 6.
} 
O modelo A proposto pelo painel, apoiado pelo Brasil, recomendava a ampliação do Conselho com seis novos assentos permanentes, sem direito a veto, e com três assentos eletivos, para mandatos de dois anos. O modelo B sugeria a criação de um assento rotativo com mandato de dois anos, e de oito semipermanentes, a ser ocupados por mandatos renováveis de quatro anos (Soares, 2005). Contudo, o tempo mostraria que nenhum dos modelos lograria ser adotado, pois, conforme atestou o próprio secretário-geral, "a política de um bom número de países que na teoria apoiam a expansão do Conselho é rejeitar na prática toda e qualquer proposta específica" (Annan, 2013: p. 178).

À mesma época, a África elaborou novo posicionamento comum em relação à reforma do CSNU, resultante da reunião do Conselho Executivo da UA na Etiópia. Não obstante a visita de Amorim a Addis Abeda, em que se reuniu com chanceleres da organização para tentar adotar uma posição comum em relação à reforma do Conselho, o G-4 e o grupo africano apresentaram projetos separados (Brigido, 2010). A posição da África, comtemplada no Consenso de Ezulwini, defendia a atribuição ao continente africano de "not less than two permanent seats with all the prerogatives and privileges of permanent membership including the right of veto" ${ }^{19}$, além de cinco assentos não permanentes.

O Consenso afirmava que a África se opunha ao poder de veto desfrutado pelos atuais membros permanentes, contudo, enquanto persistisse, deveria ser estendido aos países ocupantes dos novos assentos. A declaração defendia que caberia à União Africana se responsabilizar por critérios e processos de seleção para a escolha dos Estados que ocupariam as cadeiras destinadas ao continente no Conselho de Segurança.

O G-4, baseando-se no modelo A do Painel de Alto Nível, com o apoio de mais 24 países $^{90}$, apresentou o projeto de resolução A/59/L.64, que defendia a criação de dez assentos no CSNU, sendo seis permanentes e quatro temporários. As cadeiras permanentes deveriam ser assim distribuídas: duas para os Estados africanos, duas para os asiáticos, uma para os latinoamericanos e os caribenhos, uma para os europeus ocidentais e os demais Estados. As novas

\footnotetext{
${ }^{89}$ The Common African Position On The Proposed Reform Of The United Nations: "The Ezulwini Consensus". 08 mar. 2005. Disponível em: http://www.cfr.org/world/common-african-position-proposed-reform-united-nationsezulwini-consensus/p25444. Acesso em: 05/01/2014.

${ }^{90}$ Afeganistão, Bélgica, Butão, República Checa, Dinamarca, Fiji, França, Geórgia, Alemanha, Grécia, Haiti, Honduras, Islândia, Kiribati, Letónia, Maldivas, Nauru, Palau, Paraguai, Polônia, Portugal, Ilhas Salomão, Tuvalu e Ucrânia.
} 
cadeiras não permanentes seriam destinadas: uma para a África, uma para a Ásia, uma para a Europa do Leste e uma para a América Latina e o Caribe.

Consciente de tratar-se de questão sensível e que poderia inviabilizar a votação da proposta, o tema do direito ao veto foi apresentado com cautela na resolução. Em princípio, defendia-se a extensão desse poder aos novos membros permanentes, que, contudo, não deveriam exercer a prerrogativa do veto até que a questão fosse discutida num processo de revisão, 15 anos após a ampliação do Conselho ter entrado em vigor. Assim, almejava o G-4 evitar que a polarização de inúmeros Estados em posições antagônicas em relação ao veto não os impedisse de apoiar o projeto de resolução L.64.

O terceiro grupo formou-se, em oposição ao G-4 e ao Grupo Africano, por países contrários à ampliação dos membros permanentes do Conselho de Segurança. O antigo Coffee $C l u b^{91}$ apresentou o projeto de resolução A/59/L.68, que previa a criação de dez cadeiras não permanentes, a ser distribuídas da seguinte forma: seis assentos para a África, cinco para a Ásia, quatro para a América Latina e o Caribe, três para a Europa Ocidental e outros Estados, dois para a Europa Oriental (Freiesleben, 2013; Brigido, 2010).

Uma característica relevante do grupo "Unidos pelo Consenso" (UfC) é a de que ele reúne Estados que rivalizam as lideranças regionais com países do G-4. Assim, a Argentina e o México competem com o Brasil; o Paquistão, com a Índia; a Itália e a Espanha, com a Alemanha; a Coreia do Sul, com o Japão. A China, apesar de não ter entrado para o Uniting for Consensus, aproveita-se dessas rivalidades para inibir avanços nas negociações quanto à reforma, em especial no que se refere à postulação indiana:

Instead of openly opposing India's bid (as it does in the case of Japan), Beijing relies on "spoiler states" like Pakistan to keep its southtern rival off balance. (Malik, 2005: p. 24)

O grupo UfC é formado, adicionalmente, por países, como Colômbia, Costa Rica,

\footnotetext{
${ }^{91} \mathrm{O}$ nome remete ao fato de que seus membros, supostamente, preferiam interromper as reuniões a engajar-se, a fundo, em suas discussões. Formou-se em 1993 quando a Assembleia Geral estabeleceu o Grupo de Trabalho de Composição Aberta sobre a reforma do Conselho e permaneceu ativo por 15 anos (Garcia, 2013: p. 118) quando, em 16 de fevereiro de 2005, o grupo (Argentina, Colômbia, México, Quênia, Argélia, Itália, Espanha, Paquistão e Coreia do Sul) aprovou o documento denominado Unidos pelo Consenso, e passou a chamar-se assim (Menezes, 2010: p. 231).
} 
Turquia, Malta, Argélia, Canadá, Malta e San Marino, que, apesar de não terem ambições regionais, preferem manter o status quo. Impedem, assim, a ampliação da concessão do privilégio de veto, usufruído pelo P-5, a outros países e evitam a ascensão dos países líderes regionais postulantes às vagas permanentes ao patamar de potências mundiais (Tarragô, 2009).

O posicionamento do grupo UfC era abertamente contrário à ampliação das cadeiras permanentes do CSNU, tornando-o incompatível com as posições defendidas por outros países. As propostas do G-4 e da União Africana para reformar o Conselho evidenciavam que ambos os grupos possuíam perspectivas similares. As únicas diferenças entre o Consenso de Ezulwini e o Projeto de Resolução A/59/L.64 eram a criação de um assento não permanente adicional para a África e a extensão imediata do poder de veto aos novos membros. Dessa forma, em meados de 2005, havia esperança e expectativa de que ambos os grupos pudessem chegar a uma posição comum, o que seria essencial para que o projeto de resolução apresentado pelo G-4 fosse aprovado:

Detendo mais de cinquenta votos na Assembleia Geral, o apoio do continente africano ao projeto do G-4 quase certamente garantiria o seu êxito. Na prática, vinte ou trinta países africanos já seriam capazes de virar a maré. Todavia, a atuação do Grupo Africano nas Nações Unidas tradicionalmente se pautara pela coesão, de modo que dificilmente algum país africano se dissociaria do Consenso de Ezulwini (Vargas, 2009: p. 49).

Uma reunião ministerial foi convocada, em julho de 2005, em Londres, entre os chanceleres do G-4 e os representantes da UA, para discutir a possível conciliação das posições dos dois grupos. A reunião de Lancaster House logrou chegar a um projeto de resolução conjunto:

O texto flexibilizava a posição africana em relação ao uso do veto pelos novos membros permanentes, com a aparente aceitação (que logo se desfez) pela África da linguagem proposta pelo G-4 sobre o assunto. Em contrapartida à flexibilização sobre o veto, foi acertada, como fórmula de compromisso proposta pelo Brasil, a criação de um $26^{\circ}$ assento nãopermanente, a ser compartilhado pelas regiões do mundo em desenvolvimento (África, Ásia e América Latina e Caribe). (Oliveira, 2007: p. 175)

O "Consenso de Londres" seria, contudo, brevemente desfeito. O projeto de resolução concertado na reunião de Lancaster House tinha de ser submetido, novamente, aos chefes de Estado da UA, para ser validado. Em agosto de 2005, cerca de um mês após a ministerial na 
capital britânica, a União Africana realizou uma reunião extraordinária, em que decidiu recusar os termos do projeto acertado em Londres e manter o Consenso de Ezulwini (Amorim, 2011: p. 455). O Grupo Africano apresentou, assim, o projeto de resolução A/59/L.67, que defendia a extensão do direito de veto aos novos assentos permanentes do Conselho e dois assentos permanentes para a África. A insistência na concessão da prerrogativa do veto não apenas incompatibizou a proposta da África com a do G-4, mas também impediu que fossem feitos avanços na agenda de reforma, tendo em vista que, sem a união dos dois grupos, nenhum de seus projetos de resolução conseguiria reunir votos suficientes para ser aprovado, o que favoreceu o interesse dos países do UfC.

Um dos fatores colaboradores para esse desfecho foi o non-paper distribuído pelos EUA em julho daquele ano. Ao perceber a movimentação favorável ao projeto de reforma do G-4 e ciente de que um acordo entre a UA e os países do G-4 possivelmente lograria conquistar suficientes adesões para conseguir a maioria de votos na Assembleia, o governo norte-americano circulou documento pelo qual buscava convencer os países a votar contra a resolução do G-4: "We urge you to oppose the G-4 resolution and, should it come to vote, to vote against it or abstain. Further, we urge you to press for a delay in any vote on UNSC reform or expansion" (Costa, 2006: p. 195).

O discurso proferido por Celso Amorim em 17 de setembro, na 60 ${ }^{\mathrm{a}}$ AGNU, centrou sua argumentação em prol da premência de um Conselho mais representativo, democrático e eficaz que não perpetuasse "desequilíbrios contrários ao espírito do multilateralismo". No que tange à proposta brasileira, o ministro limitou-se a defender uma "expansão dos assentos permanentes e não permanentes com países em desenvolvimento da África, da Ásia e da América Latina em ambas as categorias" (Corrêa, 2012: p. 893). A pretensão nacional de alcançar uma vaga definitiva no CSNU não foi mencionada, tendo em vista o presidente Lula já ter discutido as propostas de ampliação em reunião de cúpula do Conselho de Segurança, três dias antes.

Amorim elencou os avanços da política externa brasileira, exemplificando o compromisso do país com "os ideais que levaram à criação da única Organização de vocação universal" (op. cit., p. 896). Os avanços enumerados pelo chanceler podem ser compreendidos como credenciais indiretas do Brasil que justificariam a concessão de preeminência ao espaço de atuação do país no âmbito internacional. O renovado interesse pelo mundo árabe, a participação 
nos esforços de paz no Haiti, o fortalecimento dos vínculos com a África, a criação do IBAS e do G-20, a integração com os vizinhos da América do Sul por meio do Mercosul foram os fatos elencados para ilustrar a capacidade de atuação global do Brasil.

$\mathrm{O}$ ano da celebração do sexagenário da ONU terminou sem que nenhuma decisão a respeito da reforma do Conselho fosse tomada. As propostas do Unidos pelo Consenso, do G4 e do Grupo Africano não chegaram, sequer, a ser votadas, e o texto final da reunião de Cúpula do Conselho de Segurança ${ }^{92}$ apenas teceu breves comentários evasivos sobre a necessidade de o órgão ser reformado. Como afirmou Freiesleben (2013), no final, a insistência africana sobre o direito de veto e as fortes oposições norte-americana e chinesa bloquearam quaisquer resultados concretos.

\section{7. $O$ arrefecimento das negociações diante da irredutibilidade dos posicionamentos}

O ano de 2006 foi caracterizado pela realização da primeira cúpula do Fórum de Diálogo entre Índia, Brasil e África do Sul (IBAS), importante marco do projeto diplomático de Lula, iniciado em 2003, que adquiriu concretude em 13 de setembro, em Brasília. O chefe de Estado brasileiro, junto com presidente sul-africano, Thabo Mbeki, e o primeiro-ministro indiano, Manmohan Singh, assinaram acordos para estimular a coordenação política em temas globais ${ }^{93}$. Outro acontecimento relevante na agenda mundial foi o impasse nas negociações da Rodada Doha da OMC, que, não obstante os esforços diplomáticos feitos pelo Brasil, teve seu processo negociador paralisado.

Em 19 de setembro, seis dias após a cúpula do IBAS, Lula voltou a dirigir-se ao plenário da AGNU, para a abertura da $61^{\mathrm{a}}$ sessão. Em sua alocução, o presidente fez uma ligação entre a temática comercial e a de segurança, indicando que "se a Rodada fracassar, (...) males, como o crime organizado, o narcotráfico e o terrorismo, encontrarão terrenos férteis para proliferar" (Correa, 2012: p. 901). Lula apontou para a "erosão de credibilidade" da ONU, que, diante dos conflitos no Oriente Médio, foi acusada pela opinião pública mundial de ser morosa e incapaz de agir com a necessária celeridade. O imperativo da reforma da ONU, em especial do seu

92 UNITED NATIONS. World Summit Outcome Document. A/RES/60/1. 14 set. 2005. Disponível em: http://www.un.org/womenwatch/ods/A-RES-60-1-E.pdf. Acesso em: 03/09/2014.

${ }_{93}$ Disponível em: http://www.ibsa-trilateral.org/images/stories/documents/declarations/1st summit declaration.pdf. Acesso em: 07/03/2014. 
Conselho, foi justificado com argumentos recorrentemente presentes no discurso brasileiro: a necessidade de o órgão tornar-se mais democrático, legítimo e representativo.

Em outubro daquele ano, durante as comemorações do $61^{\circ}$ aniversario das Nações Unidas, Amorim mencionou a importância da reforma e assinalou que a América Latina não dispor de um assento no Conselho enfraquecia a Organização. O chanceler acrescentou que se os países latino-americanos avaliassem que o Brasil não devesse ser o representante, que fosse realizada uma votação, mas que isso não impedisse a concessão de assento permanente para a região (Brigido, 2010). Na verdade, como o Brasil era o único postulante latino-americano, pode-se inferir que o pronunciamento do chanceler foi uma estratégia para que os países contrários desobstruíssem o caminho brasileiro, pois era evidente que nenhum competidor lograria conseguir o posto de representante da região.

Em 2007, volubilidades no mercado imobiliário norte-americano converteram-se na maior crise financeira mundial desde a Grande Depressão de 1930, afetando, intensamente, os mercados europeu e asiático e dominando a agenda da Cúpula do G-7/G-8 $8^{94}$, em Heiligendam. No plano interno, a situação do Brasil era estável, tendo as políticas sociais implantadas pelo governo de Lula, durante seu primeiro mandato, permitido ao país suavizar os efeitos nocivos da crise financeira na economia nacional (Correa, 2012). No contexto organizacional das Nações Unidas, reinava um sentimento de frustração, especialmente dos membros do G-4, com a morosidade das negociações em prol de um Conselho reformado.

Isso ocorria pelo fato de poucos países engajarem-se, de forma efetiva, em fazer avançar as negociações, não obstante professassem, publicamente, seu apoio à reforma do Conselho de modo a torná-lo mais representativo. A maioria das capitais envolviam-se apenas passiva e superficialmente com a questão da reforma:

To many of those countries where the level of national interest is not especially high, expressing vague or common positions probably seems a convenient way to deal with intense lobbying by opposing factions. (Swart,

\footnotetext{
${ }^{94}$ A primeira reunião do Grupo dos Sete ocorreu em 1975, sem a presença do Canadá, que foi incluído no encontro do ano seguinte, em 1976. Desde então, os sete Estados mais ricos do mundo reúnem-se, anualmente, para debater as principais questões político-econômicas mundiais. A Rússia entrou formalmente no grupo, em 1989, na Cúpula de Birmingham. Em 1999, no contexto da crise asiática, formou-se o G-20 com a inclusão de países emergentes, entre eles, o Brasil, convidados pelos membros originais do G-7. Disponível em: http://www.globalpolicy.org/social-and-economic-policy/the-three-sisters-and-other-institutions/group-of-sevengroup-of-eight-group-of-twenty.html; http://blog.risingbricsam.com/?p=2126. Acesso em: 7/03/2014.
} 
2013: p. 26).

Em setembro, o Brasil juntou-se a países de diferentes regiões do mundo em desenvolvimento, sob a lideranca da Índia e com importante coadjuvação da África do Sul, para agilizar o processo de reforma do Conselho de Segurança. A frente de países em desenvolvimento não tinha posição necessariamente coincidente quanto à substância da reforma, mas tinha, em comum, o desejo de alcançar, a curto prazo, algum resultado. Por consequinte, durante a $62^{\mathrm{a}} \mathrm{AGNU}$, foi apresentado o projeto de resolução A/61/L.69, copatrocinado por 25 países, que propôs o estabelecimento de negociações intergovernamentais, para alcançar, preferencialmente até o final daquele ano, alguns desses objetivos ${ }^{95}$ (Tarragô, 2012; Brigido, 2010; Swart, 2013):

- Expansion in both permanent and non-permanent categories;

- Greater representation of the developing countries, including island and small States;

- Representation of the developed countries and those with transition economies reflective of contemporary world realities;

- Comprehensive improvement in the working methods of the Security Council;

- Equitable geographical distribution;

- Provision for a review. ${ }^{96}$

O discurso de Lula perante essa sessão da AGNU, em 25 de setembro de 2007, foi a primeira participação do presidente na Assembleia Geral após a reeleição. O líder incitou a reformulação da instância decisória maior da ONU, sem explicitar, contudo seus pormenores. Apenas reiterou o argumento principal de "ser necessária uma maior participação dos países em desenvolvimento nos grandes foros de decisão internacional, em particular o Conselho de Segurança das Nações Unidas"; e estressou a premência da reforma conclamando: "É hora de passar das intenções à ação" (Corrêa, 2012: p. 919).

O ano subsequente, 2008, caracterizou-se, no plano internacional, pelo alastramento da crise financeira, sobretudo na Europa, e, no âmbito regional, pela criação da União de Nações Sul-Americanas (UNASUL). Quanto à reforma do Conselho, as negociações prosseguiam sem que houvesse alterações significativas nos posicionamento dos Estados-membros e dos grupos

\footnotetext{
${ }_{95}$ O projeto de resolução L.69 nunca chegou a ser levado a votação (Swart, 2013: p. 27).

96 UNITED NATIONS. General Assembly. A/62/47. 15 set. 2008. Disponível em: http://daccess-ddsny.un.org/doc/UNDOC/LTD/N07/506/04/PDF/N0750604.pdf?OpenElement. Acesso em: 03/09/2014.
} 
regionais. Diversos países começaram a incentivar a adoção de um modelo intermediário, a fim de tirar a reforma do impasse, por meio de uma solução provisória, deixando a resolução das questões mais difíceis para o segundo momento, que seria em 10 ou 15 anos $^{97}$. Contudo, essas propostas findaram não por ser adotadas, haja vista alguns países, como os membros do G-4, insistirem que a possibilidade de progressão de assentos semipermanentes para permanentes estivesse contemplada nos modelos intermediários de expansão do Conselho, o que não foi aceito pelos membros do UfC nem por outros países (Swart, 2013).

A frente de países que havia apresentado o projeto de resolução A/61/L.69, em 2007, chegou a mobilizar entre 40 e 50 delegações em apoio ao início das negociações intergovernamentais, às quais aderiram países africanos e caribenhos, e latino-americanos (Tarragô, 2010:). As negociações seriam iniciadas em fevereiro de 2009 e tratariam de cinco assuntos basilares: a prerrogativa do veto; as categorias de membros; a representação regional; o tamanho do Conselho ampliado e seus métodos de trabalho; a relação entre o Conselho e a Assembleia Geral ${ }^{98}$.

O pronunciamento de Lula na $63^{\mathrm{a}}$ AGNU, em 23 de setembro de 2008, tratou da reforma do Conselho de modo análogo ao ocorrido em anos anteriores. O argumento da composição anacrônica do CSNU, que limitava sua representatividade e legitimidade, foi evidenciado na passagem: "a estrutura vigente, congelada há seis décadas, responde cada vez menos aos desafios do mundo contemporâneo" (Corrêa, 2012: p. 934). Conquanto não tenha explicitado a candidatura do Brasil, Lula dedicou boa parte de sua alocução a apresentar possíveis credenciais brasileiras: as ações solidárias em países pobres, sobretudo os africanos; a atuação no IBAS, no G-20 e nos BRICS; as cúpulas entre a América do Sul e a África (ASA) e com os países árabes (ASPA); além do fato de ter sediado a cúpula da UNASUL. Dessa forma, salientou o presidente:

Simplesmente pelo diálogo direto, sem intermediação das grandes potências, os países em desenvolvimento têm-se credenciado a cumprir um novo papel no desenho de um mundo multipolar. (op. cit., p. 934)

O ano de 2009 foi fortemente influenciado pelas consequências da crise financeira mundial. No âmbito interno, a diminuição do crescimento econômico, a piora de índices sociais e

\footnotetext{
97 Disponível em: http://www.italyun.esteri.it/NR/rdonlyres/6CBD6845-26B3-411B-A39023FCA8B15C36/0/OEWGreport62GA.pdf. Acesso em: 03/09/2014. Brigido, 2010: p. 74.

98 UNITED NATIONS. General Assembly. A/63/960. 10 set. 2009. Disponível em: http://documents-ddsny.un.org/doc/UNDOC/GEN/N09/498/42/pdf/N0949842.pdf?OpenElement. Acesso em: 05/09/2014.
} 
as movimentações políticas para as eleições presidenciais do ano seguinte eram os principais acontecimentos a influenciar a política nacional. No que tange o contexto da reforma do Conselho, em março tiveram início as negociações intergovernamentais, no plenário informal da Assembleia Geral, nos cinco temas propostos. A primeira rodada durou dois meses e foi seguida de uma segunda, iniciada em junho, e da terceira, em setembro. Não obstante as negociações terem apontado para possível conciliação dos posicionamentos dos países, nenhum acordo logrou ser firmado (Brigido, 2010: p. 77).

O discurso de Lula proferido perante a $64^{\mathrm{a}}$ AGNU, em 23 de setembro, retomou a linha de política externa consistentemente defendida pelo seu governo e clamou por um Conselho de Segurança mais representativo, renovado e "aberto a novos membros permanentes" (Corrêa, 2012: p. 950). O presidente consagrou grande parte de sua fala a elencar as qualidades que a Organização deveria possuir e expôs a transição em direção a um mundo multipolar como possível fator de revitalização da Organização. A alocução urgia a construção de uma ordem internacional "sustentável, multilateral, menos assimétrica, livre de hegemonismos e dotada de instituições democráticas" como "a única forma de reparar tantas injustiças e de prevenir tragédias coletivas" (op. cit.,: p. 950).

Em 2010, prosseguiam as negociações intergovernamentais sobre a reforma do Conselho. Em maio, o relatório com os avanços conseguidos com as três primeiras rodadas foi encaminhado aos Estados-membros. O texto continha trinta propostas distintas de reforma, patrocianadas tanto por países individuais quanto por grupos de Estados. A multiplicidade de propostas conflitantes sobre os cinco elementos-chave da reforma confirmava a impressão de que encontrar soluções não seria tarefa fácil, contudo o texto lograva fornecer mais clareza sobre as posições e seus principais proponentes (Swart, 2013: p. 35).

Nesse contexto, realizou-se o último pronunciamento do governo Lula perante o plenário da AGNU. Coube ao ministro Amorim a incumbência, tendo em vista o envolvimento de Lula nas vindouras eleições presidenciais, que garantiriam a continuidade da gestão do PT sob o comando da futura presidenta Dilma Rousseff. O chefe da diplomacia brasileira fez, na abertura da $65^{\mathrm{a}}$ AGNU, em 23 de setembro, um balanço dos oito anos da administração de Lula e reafirmou as linhas gerais da política externa do presidente: a integração regional, o humanismo, 
a solidariedade, a promoção dos direitos humanos, as iniciativas de cooperação Sul-Sul, o estreitamento das relações com a África, a defesa do meio ambiente, o multilateralismo.

A defesa da reforma do Conselho de Segurança foi reiterada nos argumentos apresentados pelo presidente Lula ao longo dos seis anos em que se dirigiu à plenária da ONU. O apelo a favor da instância máxima das Nações Unidas ser aberta à "participação dos países em desenvolvimento, inclusive como membros permanentes" (Corrêa, 2012: p. 967) sintetizou a proposta brasileira. Os métodos de trabalho do Conselho foram igualmente objeto de crítica, e o ministro clamou por mais transparência no encaminhamento de "assuntos que interessam a toda a Humanidade" (op. cit., p. 967).

Conquanto não seja apresentado nenhum novo elemento no que tange à visão do Brasil de reforma para a ONU, Amorim elencou nova credencial brasileira, para integrar, de forma permanente, o Conselho: a inédita mediação brasileira no imbróglio nuclear do Irã, que resultou na Declaração de Teerã, de 17 de maio de 2010, e expôs a disposição brasileira em assumir maiores encargos nas ações em prol da paz e da segurança internacionais. O envolvimento brasileiro nas negociações do Oriente Médio não trouxe os resultados almejados, tendo em vista que não logrou impedir a adoção de sanções pelo CSNU contra o governo do Irã. Serviu, todavia, para mostrar ao mundo que "o Brasil tem procurado corresponder ao que se espera de um membro do Conselho de Segurança, mesmo não permanente, que é contribuir para a paz" (Corrêa, 2012: p. 967).

\subsection{Análise dos apoios recebidos}

A China adota, tradicionalmente, atitude cautelosa e cética no tocante à reforma do Conselho de Segurança, evitando expressar apoio a qualquer país específico. Houve uma inflexão, no entanto, em 2002, durante as visitas oficiais do presidente Jiang Zemin ao Brasil e à Alemanha, em que se abriu para eventual apoio implícito às candidaturas desses países. Por outro lado, a recusa chinesa em endossar as pretensões da Índia e do Japão persiste. Seja por rivalidades históricas, seja pela diminuição do poder relativo de que gozaria num Conselho ampliado, a China rejeita, aberta ou veladamente, as propostas de reforma que acarretam a perda da prerrogativa de ser a única voz asiática permanente no Conselho (Malik, 2005). 
A China é contrária à adoção de prazos temporais e considerou prematuras as iniciativas do secretário-geral da ONU, Kofi Annan, no sentido de promover a reforma no ano de comemoração do hexagenário da Organização, em 2005. Como foi visto anteriormente, aquele ano representou o ápice dos debates em torno da reforma, e, em resposta à pressão por um posicionamento, a potência asiática divulgou, em junho, um Position Paper on UN Reform, em que explicitou cinco princípios norteadores da sua política externa para a reforma das Nações Unidas:

1. The reform should be conducive to enhancing the authority and efficiency of the Council and strengthening its capacity to deal with global threats and challenges.

2. Increasing the representation of developing countries should be given priority. Developing countries, who account for more than two thirds of the UN membership, are seriously under-represented on the Security Council. This situation must be reversed.

3. More countries, the small and medium-sized ones in particular, should be given more opportunities to enter the Council on a rotating basis to participate in its decision making process.

4. The principle of geographic balance should be adhered to, with representation of different cultures and civilizations taken into consideration.

5. All the regional groups should, first of all, reach agreement on reform proposals concerning their respective regions. The principle of regional rotation advocated by some countries also merits attention and consideration. ${ }^{99}$

Entre os dois modelos de reforma sugeridos pelo Painel de Alto Nível sobre Ameaças, Desafios e Mudanças, endossados por Annan, a China posicionou-se favoravelmente ao Modelo B, que apoiava a criação de terceira categoria de membros semipermanentes, em oposição ao modelo A, defendido pelo G-4 (Panda, 2011). Percebe-se, assim, que, apesar de ter manifestado, ocasionalmente, apoio às aspirações do Brasil e da Alemanha, a China não apoia o G-4, em decorrência da rivalidade histórica e declarada com o Japão e da velada com a Índia.

Passados cinco anos, na $65^{\mathrm{a}}$ sessão ordinária da Assembleia Geral, em setembro de 2010, a China apresentou outro Position Paper, em que tratou da reforma da ONU e do Conselho. O documento estabelecia como prioridade aumentar a representação dos países em

\footnotetext{
${ }^{99}$ CHINA. Position Paper of the People's Republic of China on the United Nations Reforms. 7 jun. 2005. Disponível em: http://www.china-un.org/eng/hyyfy/t199101.htm. Acesso em: 18/02/2014.
} 
desenvolvimento, em especial os africanos ${ }^{100}$. Conquanto não tenha sido explicitado em seu posicionamento oficial, a China, "in a backdoor diplomacy" (Malik, 2005: p.24), havia-se comprometido a apoiar a concessão de uma cadeira permanente a um país muçulmano da Ásia. Dessa forma, a Indonésia, o Bangladesh, a Malásia e o Paquistão foram incentivados a candidatarem-se a uma cadeira permanente, o que consistiu em uma estratégia chinesa de incitar outros Estados a obstar avanços à agenda da reforma:

Instead of openly opposing India's bid (as it does in the case of Japan), Beijing relies on "spoiler states" like Pakistan to keep its southern rival off balance. (Malik, 2005: p. 24)

A análise dos pronunciamentos chineses demonstra serem eivados de certa ambiguidade e contradição. Ao mesmo tempo em que defendem a inclusão prioritária de países em desenvolvimento, bloqueiam a entrada da Índia. De forma análoga, não obstante as declarações do governo de Pequim sobre o Conselho já se encontrar sobrerrepresentado de "ricos e brancos" (Malik, 2005: p. 20), a potência asiática demontra simpatia ao pleito alemão conforme dito anteriormente.

A oposição chinesa foi um dos fatores apontados como responsável pelo fracasso da tentativa de construir um projeto de reforma comum entre o G-4 e a União Africana. A presença chinesa na África cresceu vertiginosamente nas últimas décadas, e o perfil discreto que o país desempenhava na região, até poucas décadas atrás, não mais corresponde à realidade contemporânea. Atualmente, o país "has its multinational corporations actively involved in Africa, with more than seven hundred companies operating in forty-nine African countries in businesses from oil to hotel management" (Alao, 2007: p. 271). Isso ocasionou um crescimento vertiginoso do volume de comércio sino-africano, que, em 1999 não passava de US\$ 2 bilhões e, em 2006, alcançou o patamar US\$ 55.5 bilhões (Escosteguy, 2011).

A crescente participação de empresas chinesas em negócios africanos influiu, sobremaneira, na condução das políticas externas dos países do continente, evidenciada no fato de, simultaneamente ao aumento dos investimentos econômicos e comerciais chineses na região, ter ocorrido um incremento das relações diplomáticas sino-africanas. As iniciativas de aproximação incluíram visitas de políticos do alto escalão do Partido Comunista chinês, tendo o

\footnotetext{
${ }^{100}$ CHINA. Position Paper of the People's Republic of China at the 65th Session of the United Nations General Assembly. 14 set. 2010. Disponível em: http://www.china-un.org/eng/hyyfy/t752396.htm. Acesso em: 18/02/2014.
} 
ex-presidente Hu Jintao viajado ao continente africano cinco vezes, entre 1999 e 2007 . A criação do Foro de Cooperação China-África (Focac), em 2000, aumentou a assistência financeira disponível às nações africanas, com a concessão de novas linhas de crédito, fato representativo da busca por aproximação entre as duas regiões (Escosteguy, 2011).

Oficialmente, a postura da China foi a de não intervenção nos assuntos internos africanos, apresentando-se "como parceira disposta a investir e a oferecer assistência e cooperação econômica, sem impor condicionalidades" (Escosteguy, 2011: p. 84). Todavia, a influência chinesa nas políticas externas e internas africanas fez-se evidente em matéria de paz e segurança. Apesar de a potência asiática não ter-se posicionado, formalmente, contra a reforma do CSNU, sua atitude conservadora contribuiu para incompatibilizar as posições dos atores envolvidos no consenso (Brigido, 2010).

Similarmente, a atuação dos Estados Unidos foi outro fator que coibiu a formação de um acordo sobre a reforma das Nações Unidas. Em 2005, no auge do momentum favorável, o nonpaper do governo norte-americano urgiu, de forma enfática, que os países rejeitassem a proposta do G-4. O documento delineava os critérios que os EUA consideravam importantes para a ascensão de um país a membro permanente do Conselho ${ }^{101}$ e reafirmava apoio apenas à candidatura do Japão: "we continue to regard Japan as a clearly qualified candidate for a SC seat, and we support it" (Costa, 2006: p. 196).

O governo norte-americano mantinha, assim, a defesa da ampliação do Conselho de Segurança para não mais de 20 membros e o apoio, somente, à candidatura do Japão de forma constante e explícita. Quanto aos demais membros do G-4, os EUA adotavam uma posição ambígua e menos assertiva. Apesar de ter demonstrado, em alguns momentos, suporte à candidatura da Alemanha, isso não mostrou ser o caso sempre:

Ao contrário da administração Clinton, o presidente George W. Bush foi bastante claro em sua oposição a dar um lugar permanente para a Alemanha, uma posição frequentemente atribuída à oposição da Alemanha à guerra contra o Iraque em 2003. (Menezes, 2009: p. 246)

O posicionamento norte-americano pendeu, favoravelmente, à inclusão de Brasil e Índia

\footnotetext{
${ }^{101}$ Os fatores elencados eram: "size of economy and population, military capacity, contributions to peacekeeping operations, commitment to democracy and human rights, financial contributions to the United Nations, nonproliferation and counterterrorism, and geographic balance" (Costa, 2006: p. 195).
} 
nas cadeiras permanentes do Conselho, como forma de auferir maior representatividade e legitimidade ao órgão por meio do aumento da participação de países emergentes. Em outubro de 1997, o presidente Bill Clinton visitou o Brasil e mencionou ser favorável a uma vaga permanente para a América Latina (Arraes, 2005). Dez anos depois, o então presidente norteamericano, George W. Bush, afirmou, em seu pronunciamento perante a $62^{\text {a }} \mathrm{AGNU}$, que os EUA estavam abertos a considerar "outros países" como postulantes a assentos permanentes. Condoleezza Rice, então secretária de Estado do governo republicano, corroborou a declaração do presidente, ao afirmar à revista Foreign Affairs ${ }^{102}$ que os EUA reconheciam a emergência de novas potências, em particular, a Índia e o Brasil e ao defender que as instituições internacionais fossem modificadas para refletir essa nova realidade. Rice declarou que o governo Bush apoiaria uma expansão "razoável" do Conselho (Viotti, 2010: p. 93).

A assunção de Barack Obama à Presidência, em 20 de janeiro de 2009, não ocasionou mudanças significativas em relação ao posicionamento norte-americano. A atual administração dos EUA permanece favorável a uma reforma modesta, que não comprometa a eficiência do Conselho, mantendo-a em certos limites numéricos, sem o Conselho ultrapassar os vinte e um membros (Tarragô, 2010). Em visita presidencial à Índia, em novembro de 2010, Obama afirmou: "posso dizer hoje que, nos próximos anos, torcerei por um Conselho de Segurança que inclua a Índia como membro permanente" ${ }^{103}$. De forma análoga, em declaração conjunta com a presidente Dilma, em março de 2011, o presidente norte-americano expressou "apreço à aspiração do Brasil de tornar-se membro permanente do Conselho"104.

A Europa mantém-se dividida em seu posicionamento sobre a reforma do Conselho. O Tratado de Lisboa, em vigor desde dezembro de 2009, tem como um de seus objetivos promover coesão na política externa europeia. Os principais países europeus possuem, no entanto, concertação política restrita em questões de segurança internacional, inter alia, na reforma do

\footnotetext{
${ }^{102}$ Rice, Condoleezza. Rethinking the National Interest: American Realism for a New World. Foreign Affairs: July/August, 2008. Disponível em: http://www.foreignaffairs.com/articles/64445/condoleezza-rice/rethinking-thenational-interest. Acesso em: 05/05/2013.

${ }_{103}$ OBAMA, Barack. EUA pedem Índia no Conselho de Segurança. Folha de São Paulo. Mundo. 09 nov. 2010. Disponível em: http://www1.folha.uol.com.br/fsp/mundo/ft0911201002.htm. Acesso em: 02/01/ 2013.

${ }^{104}$ Comunicado Conjunto da Presidenta Dilma Rousseff e do Presidente Barack Obama. Brasília, 19 mar. 2011. Disponível em: www.itamaraty.gov.br/salade imprensa/noas-a-imprensa/comunicado-conjunto-da-presienta-dilmarousseff-e-do-presidente-barack-obama-brasília-19-de-marco-de-2011. Acesso em: 03/05/2014.
} 
Conselho. A tensão pendular existente entre os interesses gerais europeus e os individuais de cada Estado tem resultado na polarização das condutas dos governantes em prol das demandas restritas e em detrimento das ações coordenadas de alcance mais amplo (Pirozzi \& Ronzitti, 2011).

A Itália, principal líder do grupo UfC, é contrária à expansão dos assentos permanentes e favorável à criação de uma categoria intermediária de membros com mandatos mais longos e possibilidade de imediata reeleição. Entrementes, a Espanha, também integrante do UfC, é contra a ampliação das cadeiras permanentes. As gestões da diplomacia presidencial de Lula lograram fazer que a nação hispânica declarasse, em nota à imprensa, por ocasião da XIII Cúpula IberoAmericana, em novembro de 2003, que compreendia "as razões da postulação do Brasil a um assento permanente no Conselho de Segurança das Nações Unidas" e, no caso de sua ampliação, "manifestava simpatia" à aspiração do Governo brasileiro (Brasil, 2007: p. 113).

Conforme elucidado anteriormente, a Alemanha é integrante do G-4, havendo, portanto, apoio mútuo entre as candidaturas alemã e brasileira. A nação germânica defendeu a expansão dos assentos permanentes para os membros do grupo ao qual pertence e a concessão de duas cadeiras a países africanos conforme constava no Projeto de Resolução A/59/L.64, apresentado em 2005. Todavia, mesmo antes da formação do G-4, em 2004, o país teutônico já havia manifestado seu apoio ao Brasil em comunicado conjunto, por ocasião da visita do primeiro ministro alemão, Gerhard Schöder, em fevereiro de 2002 (Brigido, 2010).

Os dois membros permanentes da Europa hoje, Reino Unido e França, conseguiram alcançar um denominador comum no que concerne à reforma do Conselho, que, veiculado em declaração conjunta de julho de 2009, explicita que ambos os países apoiam as candidaturas do Brasil, da Índia, do Japão e da Alemanha, além da criação de uma cadeira permanente a um representante africano. As nações anglo-saxã e gaulesa defendem a adoção de uma solução intermediária que proveria o Conselho de nova categoria de membros eletivos, mas com mandatos mais longos que os dos atuais membros temporários. Ao final de um período a ser estabelecido, essa solução provisória seria objeto de uma revisão que converteria as cadeiras 
semipermanentes em definitivas ${ }^{105}$.

A posição da Rússia em relação à reforma do Conselho é eivada de certa imprecisão e foi alterada no decorrer dos anos. Em novembro de 1997, durante visita ao Brasil, o ministro das Relações Exteriores daquele país, Ievguêni Primakov, declarou que a Rússia aquiescia com a necessidade de a América Latina estar representada no Conselho. O político russo alegou, contudo, que isso não significava um apoio à aspiração brasileira, pois a questão de quem ocuparia esse posto deveria ser resolvida entre os países latino-americanos ${ }^{106}$. Em janeiro de 2002, a Rússia manifestou-se a favor do pleito brasileiro, em declaração conjunta feita por ocasião da visita presidencial de Fernando Henrique Cardoso àquele país:

A Federação da Rússia afirmou considerar o Brasil, membro influente da comunidade internacional, como um dos candidatos apropriados para ocupar vaga de membro permanente, no contexto de um possível acordo sobre a ampliação do Conselho de Segurança nas categorias de membro permanente e não permanente. ${ }^{107}$

O apoio de Vladmir Putin à aspiração do Brasil ocorreu em troca do suporte brasileiro que a Rússia receberia a sua entrada na $\mathrm{OMC}$, só realizada em agosto de 2012, após dezoito anos de negociações ${ }^{108}$. Recentemente, a Rússia expressou-se favorável a explorar modelos provisórios de expansão que sugerem a criação de uma categoria intermediária de assentos semipermanentes (Gowan, 2014). Quanto ao poder de veto, o país nunca admitiu mudança nas prerrogativas dos atuais membros. Há apoio russo ao pleito brasileiro ao assento permanente no Conselho, mas é moderado e condicionado (Tarragô, 2009; Malik, 2005).

A Rússia e os EUA foram os membros permanentes que maior ênfase conferiram à noção de uma expansão limitada do Conselho de modo a não comprometer a eficácia do órgão. A nação eslava advoga a importância de que seja alcançado amplo acordo político para a adoção da reforma, para não serem produzidos antagonismos entre os países membros. Idêntico argumento

105 UK-French Summit: Declaration on Global Governance and Development. 6 jul. 2009. Disponível em: http://www.franceonu.org/france-at-the-united-nations/press-room/speaking-to-the-media/press-releases/article/6july-2009-uk-french-summit. Acesso em 20/08/2014.

106 PRIMAKOV, Ievguêni. Folha de São Paulo. Brasil. 26 nov 1997. Disponível em: http://www1.folha.uol.com.br/fsp/1997/11/26/brasil/48.html. Acesso: 21/08/2014. Arraes, 2005: p. 11.

${ }^{107}$ Declaração Conjunta Brasil-Rússia. Brasília. 14 jan. 2002. Disponível em: http://www.itamaraty.gov.br/sala-deimprensa/notas-a-imprensa/2002/01/14/declaracao-conjunta-brasil-Rússia. Acesso: 21/08/2014.

108 JUSTO, Marcelo. BBC Mundo. Rússia entra na OMC e encerra capítulo 'econômico' da Guerra Fria. 22 ago. 2012. Disponível em: http://www.bbc.co.uk/portuguese/noticias/2012/08/120822 russia omc lgb.shtml. Acesso em: 21/08/2014. 
é reiteradamente empregado pela China, que apoia, oficialmente, a reforma, mas reivindica que a decisão seja tomada por vasta maioria, maior que os dois terços prescritos pela Carta para a realização de emendas (Tarragô, 2010; Viotti, 2010).

Quanto ao posicionamento dos países latino-americanos, o lançamento oficial da candidatura brasileira não logrou obter adesão regional irrestrita. Conquanto a região fosse favorável à reforma do Conselho, nunca houve uma deliberação unânime sequer a respeito de se deveria haver um assento permanente destinado à América Latina, quanto mais sobre quem seria seu representante. Amorim afirmou, em pronunciamento na AGNU, em setembro de 1994, que a candidatura do Brasil ia ao encontro do posicionamento das nações latino-americanas acerca dessa questão, tendo em vista os países do Grupo do Rio, em setembro de 1994, terem declarado que a região deveria estar contemplada numa ampliação do Conselho (Barreto, 2012a). Todavia, apesar da declaração de defesa da concessão de cadeiras no Conselho para o continente, os vizinhos não balizavam a representação pelo Brasil.

A Argentina sempre se mostrou contrária à ampliação das cadeiras permanentes e defendeu a rotatividade de eventual vaga latino-americana no Conselho. O lançamento da candidatura brasileira, em 1994, causou irritação ao país platino, pois a aspiração de Amorim reforçaria a liderança do Brasil e o credenciaria como principal interlocutor da região junto às grandes potências (Bernal-Meza apud. Brigido, 2010). Assim, a oposição argentina deve ser entendida em termos de uma tentativa de manutenção do seu equilíbrio regional de poder (Brigido, 2010) conforme demonstrou o então presidente argentino, Carlos Menem, em 1997, ao afirmar que a "categoria de membro permanente não deve ser introduzida nas regiões em que não existem" (Menem apud. Arraes, 2005: p. 13).

O governo Cardoso foi, por isso, especialmente cauteloso com a aspiração brasileira a fim de que não causasse prejuízos às relações com a Argentina nem com outros países vizinhos resistentes ao pleito nacional, como o México e a Colômbia (Sardenberg, 2010). O presidente chegou a declarar, em 1994, que, entre a cadeira no Conselho e o relacionamento com a Argentina, ficaria com a segunda opção (Cardoso apud. Brigido, 2010). Em seu segundo mandato, após sua reeleição, Cardoso voltou a reafirmar a primazia do Mercosul e da relação com a Argentina como "prioridade mais elevada de sua política exterior" (Brigido, 2010: p. 163). 
A posição oficial do Brasil foi, até o final do Governo Cardoso, a de não apresentar a questão do lugar no Conselho como uma meta obsessiva de sua política exterior, salvaguardando em quaisquer das hipóteses futuras do desenlace do assunto, o princípio de que o debate não seja colocado em termos que enfraquecam a relação entre Argentina e Brasil (Ayllon apud. Brigido, 2010: p. 162).

Durante o governo de Lula, novas estratégias lograram aumentar a base de adesão regional à candidatura brasileira. Lula usou como tática angariar apoios em encontros presidenciais bilaterais. Dessa forma, em abril de 2003, o então presidente da Bolívia, Gonzalo Sánchez de Lozada, durante visita ao país, afirmou que, se o Brasil fosse indicado como membro permanente do Conselho de Segurança da ONU, não envergonharia nenhum país da América do Sul (Lozada apud. Brigido, 2010). De forma análoga, o Equador manifestou apoio à candidatura brasileira durante vistia de seu presidente, Lucio Guitiérrez, em maio de 2003, e o Suriname, em julho do mesmo ano. Em abril de 2006, foi a vez de o Chile manifestar apoio ao pleito brasileiro por ocasião da visita de sua presidenta Michelle Bachelet. Em 2008, o Brasil recebeu manifestações de apoio da Guatemala e de Cuba (Brigido, 2010).

Em relação aos apoios recebidos do continente africano, a investigação demonstrou que, desde a retomada das discussões após o final do conflito bipolar, em 1992, com a Resolução 47/62, até meados de 2005, houve um processo de convergência das posições brasileira e africanas em relação à reforma do CSNU. O comentário enviado pelo Brasil ao secretário-geral da ONU, em 1993, não previa a África entre os assentos permanentes do Conselho ampliado. Esse posicionamento seria inconciliável com o da OUA, que se manifestou a favor de 2 assentos permanentes para o continente africano.

Nos pronunciamentos seguintes dos representantes africanos sobre o tema, tanto na Declaração de Harare, de 1997, quanto no Consenso de Ezulwini, de 2005, houve continuidade na posição adotada pelo continente, salvo no que diz respeito à prerrogativa do veto. A diferença no posicionamento africano foi sutil, mas significativa. A África sempre se manifestou contrária ao poder de veto. Em Harare, essa prerrogativa seria estendida aos novos membros, até ser extinta. Era uma postura mais flexível. Em Ezulwini, a abolição do veto não é mencionada, e sua concessão aos novos membros permanentes é defendida de forma premente.

A atitude brasileira em relação à agenda de reforma do Conselho evoluiu, com a entrada do país para o G-4, para uma proposta mais próxima da defendida pela UA, prevendo dois 
assentos permanentes para a África e um não permanente. Por ser a questão do veto ponto nevrálgico das negociações, o Grupo dos 4 propôs adiar a decisão sobre o tema para uma revisão da reforma a ser realizada 15 anos após sua implantação. As principais diferenças entre o projeto de resolução apresentado pelo G-4 e o Consenso de Ezulwini consistiam na concessão de um assento não permanente a mais para a África e na extensão do veto. A rigidez na defesa da concessão do veto aos novos membros do futuro CSNU ampliado foi o grande ponto de inflexão do posicionamento africano que contribuiu para o fracasso das negociações com os representantes do G-4 em meados de 2005, em Londres.

Faz-se necessário, ainda, pormenorizar o apoio que o Brasil recebeu de alguns países daquele continente. O presidente da Gâmbia, Yahya Jammeh, em agosto de 2005, disponibilizouse a colaborar com a conciliação das propostas do G-4 e do Grupo Africano. Os presidentes de Cabo Verde, Pedro Pires, em outubro de 2005, e o de São Tomé e Príncipe, em agosto do mesmo ano, igualmente, reiteraram seus apoios à candidatura brasileira. No ano seguinte, em fevereiro, o Brasil recebeu o apoio de Botsuana e, em julho, de Gana, ambos em visitas dos presidentes destes países ao Brasil. Em 2007, o Brasil teve o apoio do Senegal durante a visita do presidente Abdoulaye Wade e, em 2008, da Namíbia e da África do Sul (Brigido, 2010).

$\mathrm{O}$ apoio recebido na candidatura ao Conselho era recíprocado com ajuda em questões diversas. Nos casos de países mais pobres, capacitações em programas sociais, urbanísticos, sanitários, energéticos, de combate à AIDS, de desenvolvimento agrícola, de infraestrutura foram as mais comuns. O governo brasileiro negou que as concessões feitas aos Estados visassem ao apoio deles à candidatura brasileira, contudo, mesmo que a finalidade não fosse essa, é inegável que houve certa influência, principalmente no caso das nações mais carentes (ibid.).

Além dos países mencionados, durante seus dois mandatos, o presidente Lula conseguiu a adesão de outros ao pleito nacional. A listagem feita neste capítulo priorizou os apoios mais significativos e relevantes, mas não é exaustiva, podendo-se acrescentar países islâmicos, como Irã; da Europa do leste, como Eslovênia, Letônia, Cazaquistão; europeus, como Bélgica, Noruega, Finlândia; asiáticos, como Vietnã, Filipinas (ibid.).

Uma análise pormenorizada do período compreendido pelos mandatos duplos de Cardoso e Lula faz-se necessária, haja vista a ampla abrangência temporal. O capítulo seguinte explorará, em detalhe, os dezesseis anos estudados. Pode-se antecipar que a observação da condução da 
candidatura nos governos de Cardoso e Lula, percebeu não uma ruptura, mas uma mudança de ênfase. Enquanto Amorim, no governo de Itamar e posteriormente, quando voltou a ocupar a chefia do MRE com Lula, defendia, abertamente, o Brasil como candidato, Lampreia, não assumia, de forma explicita, a candidatura, mas apenas defendia a reforma e mostrava que o país estaria disposto a assumir tal responsabilidade. Mesmo essa abertura a assumir tal encargo não foi constante durante os dois mandatos de FHC, pois, durante os anos de 1999 e 2000, sob influência da crise monetário-financeira que acarretou a desvalorização da moeda, o chanceler chegou a negar a disposição do país em aumentar sua participação no gerenciamento da ordem internacional (Barreto, 2012). 


\section{CAPÍtULO 3 \\ Análise comparativa das candidaturas}

Amour-propre is perhaps the most marked characteristic of the Brazilian nature (...)

Sir B. Alston ${ }^{109}$

Algumas considerações preliminares fazem-se necessárias para que se possa realizar a análise comparativa entre as candidaturas de 1921-1926 e de 1994-2010. Em primeiro lugar, tratar-se-á, brevemente, do momento em que o Brasil foi cogitado para ser o sexto membro do Conselho de Segurança na época da fundação da ONU, entre 1944 e 1945, e de como o tema da reforma foi discutido até seu relançamento, em 1994. Realizar-se-á breve estudo para compreender em que medida os elementos encontrados nos demais períodos históricos estiveram presentes nas ocasiões não enfocadas por esta dissertação. Em seguida, tendo em vista a extensão do período da candidatura recente ao Conselho, examinar-se-ão, comparativamente, as mudanças existentes entre as gestões de Cardoso e de Lula, para, posteriormente, proceder à comparação desse período com o da Primeira República. Posteriormente, serão definidos os critérios empreendidos para realizar a comparação e, finalmente, proceder-se-á à análise comparativa propriamente dita.

\subsection{A candidatura indireta do Brasil ao Conselho de Segurança em 1944-1945}

Durante a Segunda Grande Guerra, foram realizadas diversas conferências em preparação para a ordem internacional vindoura. Os EUA emergiam como grande potência mundial e lideravam a formação desse novo ordenamento, estruturado em torno de instituições que solidificavam a posição favorável obtida por aquele país após a Guerra, contribuindo para prolongar sua configuração vantajosa de poder (Ikenberry, 2001). As conferências que orquestraram a criação desse novo sistema internacional foram divididas por áreas temáticas. Bretton Woods assentou as bases da nova ordem econômica; Yalta delineou as fronteiras e as esferas de influência do pós-guerra; Potsdam especificou outras condições dos acertos de paz;

${ }^{109}$ Alston a Chamberlain, confidencial, Annual Report, 1928, 23/02/1929. FO 371/13468, rolo 37. 
Dumbarton Oaks focalizou o âmbito político e assentou as bases da futura Organização das Nações Unidas ${ }^{110}$ (Moura, 2012).

As pré-condições para o surgimento da ONU foram negociadas, portanto, em Dumbarton Oaks, no Distrito de Columbia, nos EUA, entre 21 de agosto e 7 de outubro de 1944. Um dos principais temas debatidos pelos representantes das três potências vencedoras da Segunda Guerra, além da China ${ }^{111}$, foi o da composição do futuro Conselho de Segurança. De acordo com a concepção de Roosevelt, os assentos permanentes deveriam destinar-se aos "quatro policiais", que implantariam um sistema de "tutela dos poderosos" sobre as demais nações (Garcia, 2012: p. 31). A necessidade de estabelecer um órgão restrito às grandes potências baseava-se na:

Responsabilidad efectiva que pesaba sobre ellas en la organización de la paz. Esta no dependía de la buena disposición y de las declaraciones generosas de las pequeñas potencias; sino de los recursos de que disponían las grandes y de su disposición de emplearlos en una política de paz. (Belaunde, 1945: p. 55)

O quinto membro permanente do Conselho, a França, foi incorporado em razão da demanda britânica, que desejava ver aquele país retornar ao status de grande potência, apesar de sua degradante derrota na ocupação nazista, para compartir os custos de manutenção da paz no continente europeu (Hilderbrand, 1990). A emergência do Brasil como possível integrante permanente do órgão teve origem na sugestão do presidente norte-americano, lançada durante a conferência.

Nas reuniões do grupo norte-americano preparatórias para a Conferência, o secretário de Estado norte-americano, Cordell Hull, "decided to request a permanent seat for Brazil based on its size, resources, and active participation in the war agaisnt Germany" (Hilderbrand, 1990: p. 124). Roosevelt concordou com a análise de Hull, mas isso não logrou a adesão da maioria dos membros do grupo americano. Assim, em Dumbarton, o presidente dos EUA apresentou a proposta de aumentar o número de assentos permanentes no Conselho de Segurança de modo a incluir um país latino-americano, possivelmente o Brasil. Sua iniciativa gerou dissenso, não

\footnotetext{
${ }^{110}$ A expressão Nações Unidas foi cunhada na Declaração de 1942, feita pelos representantes dos EUA, do Reino Unido, da URSS e da China, à qual aderiram outras 22 nações. Apenas os países que aderiram à Declaração das Nações Unidas e que declararam guerra à Alemanha e ao Japão foram convidados a participar da Conferência de São Francisco em 1945. Disponível em: http://www.un.org/en/aboutun/history/declaration.shtml. Acesso em: 20/05/2013.

${ }^{111}$ Estiveram presentes na Conferência os subsecretários de Estado norte-americano, Edward Stettinius, o britânico, Sir Alexander Cadogan, o embaixador soviético, Andrei Gromyko, e, posteriormente, o da China, Wellington Koo.
} 
tendo sido conclusivamente discutida pelo governo norte-americano, tendo em vista que não logrou obter consenso na delegação que compareceu à Conferência (Moura, 2012; Garcia, 2012; Hilderbrand, 1990).

Além dos vínculos históricos e dos fatores estruturais que uniam o Brasil à potência norte-americana, o contexto do início da década de 1940 foi particularmente favorável à relação entre os dois países. A importância estratégica do Brasil para a vitória aliada, com a utilização de bases localizadas no Nordeste pelo exército norte-americano, associada às afinidades pessoais entre Roosevelt e Getúlio Vargas, a visão favorável de Cordell Hull e a ameaça representada pela Argentina, simpatizante com o Eixo, fortaleceram a representação brasileira de ser o "bom vizinho" dos EUA (Garcia, 2012: p. 102).

A conjuntura favorável ao Brasil da Segunda Guerra, em que a necessidade estadunidense de conseguir o apoio do país à causa aliada levou-o a fazer concessões a favor do Brasil, deu aos dirigentes brasileiros a ilusão de que o país tinha um potencial maior do que era o caso. Segundo Gerson Moura, "o próprio governo dos Estados Unidos estimulou esta superestimação da força do Brasil em nível internacional, constantemente se referindo ao seu status 'potência associada"' (Moura, 2012: p. 157), o que só viria a ser esclarecido com o fím da guerra e o declínio acentuado da capacidade de barganha do país.

Também na Conferência de Dumbarton Oaks, quando a delegação dos EUA aventou a hipótese de incluir o Brasil como sexto membro do Conselho, os representantes do Reino Unido e da URSS posicionaram-se firmemente contrários a essa aspiração, com a alegação de não aumentar o número de membros permanentes para mais do que cinco. Havia a percepção de que a participação do Brasil no Conselho seria uma forma de ampliar o poder dos EUA no órgão, dando um voto duplo a esse país. Isso ocorria tendo em vista a política externa brasileira da época preconizar o alinhamento dos posicionamentos brasileiros com os dos norte-americanos, conforme explicitado na Doutrina Aranha, com a seguinte fórmula: "apoiar os Estados Unidos no mundo, em troca de seu apoio na América do Sul" (Garcia, 2012: p.76, 337).

Ao ser informado das propostas adotadas em Dumbarton Oaks, após terminada a conferência, por meio de um memorando da Embaixada dos EUA no Brasil, de 9 de outubro de 1944, uma comissão de notáveis foi convocada pelo ministro dos Negócios Exteriores, Pedro Leão Velloso, a pedido de Vargas, para analisar a proposta e formular a resposta que seria 
encaminhada ao Departamento de Estado norte-americano. Ao final das discussões, prevaleceu a postura defendida pelo presidente de apoiar a concessão do sexto assento permanente a um país da América Latina, mas não explicitando, publicamente, a indicação do Brasil para a vaga. Optou-se, portanto, por fazer-se uma campanha velada, em que a pretensão do Brasil de ocupar o sexto assento só foi explicitada em diálogos bilaterais com os EUA (Garcia, 2012).

Em dezembro de 1944, a iniciativa dos EUA já havia perdido momentum. Naquele mês, a Embaixada norte-americana no Rio de Janeiro recebeu comunicação do governo dos Estados Unidos, instruindo-a a informar ao governo brasileiro que a potência do norte não iria persistir na indicação do Brasil como o sexto membro do Conselho, tendo em vista a rejeição da proposta pelas demais grandes potências, o que poderia acarretar a perda de apoio em outras questões vitais para os EUA. Na Conferência de Yalta, realizada entre 4 e 11 de fevereiro de 1945, a questão da candidatura brasileira já havia sido eliminada da agenda norte-americana, não tendo sido, portanto, objeto de discussão naquela ocasião (Hilderbrand, 1990; Garcia, 2012)

Logo após a reunião em Yalta, o novo secretário de Estado norte-americano, Edward Stettinius, que tinha assumido a pasta em novembro de 1944, realizou visita ao Brasil. Vargas aproveitou a oportunidade para interrogar Stettinius sobre as chances de o Brasil ganhar um assento permanente no Conselho de Segurança, e Stettinius respondeu que "não houve mudança nas discussões sobre esse ponto desde Dumbarton Oaks" (Moura, 2012: p. 164-165), evidenciando, assim, o fato de que a candidatura brasileira não havia sido discutida em Yalta. O fim do momentum favorável ao Brasil ficaria mais evidente com a mudança do governo norteamericano, ocorrida em abril daquele ano, quando Truman sucedeu Roosevelt na Presidência dos EUA e endureceu a política em relação ao nacionalismo de Vargas (Visentini, 2013).

Quando o Brasil despendeu esforços a favor da cadeira permanente, na Conferência de São Francisco, realizada entre os meses de abril e junho de 1945, com a proposta de emenda à Carta no âmbito do comitê responsável por discutir a estrutura e os procedimentos do futuro Conselho de Segurança, a janela de oportunidade já se havia fechado na ONU. O representante brasileiro na conferência, Leão Velloso, retirou o pleito brasileiro quando percebeu que a emenda não receberia o endosso norte-americano e que a insistência poderia ocasionar uma derrota da diplomacia brasileira, marcando o fim definitivo da possibilidade de o país ocupar um assento permanente na instância máxima da ONU, na origem desta Organização. 
A candidatura indireta realizada pelo Brasil não chegou a ter consistência temporal e argumentativa para incitar uma análise comparada com os demais períodos. A iniciativa durou poucos meses, não tendo, sequer, sido explicitada nos discursos oficiais do país, tendo em vista que, na Conferência de São Francisco, o representante brasileiro retirou a demanda brasileira. Notou-se, contudo, uma semelhança entre esta e o pleito da década de 1920. A campanha realizada na Liga iniciou-se com a proposta do representante chileno Agustin Edwards, e a campanha após a Segunda Guerra foi resultado de uma iniciativa do presidente norte-americano Franklin Roosevelt.

\subsection{Período de incubação}

Após o fracasso da campanha indireta para colocar o Brasil, em caráter permanente, entre as grandes potências no órgão responsável pela paz e pela segurança internacionais, a aspiração de possuir um assento permanente no Conselho de Segurança ficou amortecida. Durante o período compreendido entre 1945 e 1994, o tema da reforma foi mencionado em poucos pronunciamentos do governo brasileiro, no âmbito da Assembleia Geral e nas demais instâncias da ONU. A ambição do país em ascender à condição de membro permanente foi meramente tangenciada pelos discursos oficiais, deixando-a transparecer, mas de forma implícita, como exemplificam o discurso do então chanceler Affonso Arinos de Melo Franco, em 1962, que defendeu a ampliação dos órgãos onusianos, para melhor representar os novos membros afroasiáticos; e o do embaixador Mario de Pimentel Brandão, em 1953:

Na minha opinião, é necessário que mais cedo ou mais tarde nós prossigamos, na ordem prescrita, com a revisão da Carta, para que a Organização se encontre em melhor posição para chegar ao máximo de seus objetivos e, portanto, eliminar as críticas que foram levantadas contra ela. Esta revisão deveria ser feita de maneira objetiva e imparcial, tirandose vantagem da experiência adquirida nos últimos anos. Se de fato a Carta das Nações Unidas contém defeitos e imperfeições, e se todos nós estamos cientes de sua existência, por que não lidar com esse problema e tentar encontrar um remédio para ele. A Carta não é apenas um documento político e jurídico que serve como guia e um código de disciplina; a Carta é na verdade a expressão de um tipo de plebiscito político, jurídico e moral, que expressa os desejos de nosso mundo. (Corrêa, 2012: p. 122) 
O período do regime militar foi caracterizado, majoritariamente, pelo afastamento do Brasil dos esforços pela manutenção da paz e da segurança internacionais. Durante praticamente duas décadas, de 1969 até 1988, o país ausentou-se do Conselho como membro não permanente. O processo interno da redemocratização brasileira foi contemporâneo ao fim da bipolaridade atávica entre as duas superpotências, que imobilizava as ações do Conselho. Os anos 1990 caracterizaram-se, assim, pela renovação do órgão e pelo consequente aumento do interesse da opinião pública mundial pelas suas atividades e pela sua composição. Naquela década, o Brasil ocuparia cadeira temporária do órgão nos biênios 1988-1989, 1993-1994 e 1998-1999.

Considerado por alguns autores marco inicial do pleito brasileiro por um assento permanente, o discurso do ex-presidente José Sarney perante a 44 ${ }^{\mathrm{a}}$ AGNU, em 1989, propôs uma "reavaliação" do órgão para que a multipolaridade daquele período fosse refletida no Conselho, "a fim de habilitá-lo a melhor exercer suas responsabilidades" (Corrêa, 2012: p. 625). O presidente defendia, para isso, a criação de nova categoria de membros permanentes a qual não disporia do recurso ao veto. O discurso de Sarney abria precedente para crescente atenção que o tema teria na agenda internacional e na interna. O relançamento oficial do pleito brasileiro, ocorrido durante o governo do presidente Itamar Franco, em 1994, após a nomeação do embaixador Celso Amorim como ministro das Relações Exteriores, tornou a defesa desta aspiração continuamente presente nos discursos dos chanceleres e dos presidentes brasileiros na ONU e em outros fóruns multilaterais.

\subsection{As Políticas Externas de Cardoso e de Lula}

As diferenças ideológicas e programáticas existentes entre o Partido dos Trabalhadores (PT) e o Partido da Social Democracia Brasileira (PSDB) são notórias. O ex-presidente Luiz Inácio Lula da Silva foi um dos principais opositores ao governo Cardoso e fundamentou seus discursos, ao longo de seu governo, na necessidade de mudar as políticas implantadas pela administração do presidente Cardoso (Vigevani \& Cepaluni, 2007). Não há consenso na literatura, todavia, quanto a se houve prevalência de mudanças ou de continuidades nas políticas externas conduzidas por esses presidentes, durante seus respectivos mandatos (Vilela e Neiva, 2011). 
O debate quanto à prevalência de continuidades ou rupturas entre os governos de Cardoso e Lula divide opiniões de relevantes internacionalistas e cientistas sociais. Amado Luiz Cervo considera que as mudanças na orientação da política externa brasileira foram significativas. Os presidentes seriam movidos por paradigmas ${ }^{112}$ contraditórios: "o primeiro (FHC) nutria suas ideias e decisões com a filosofia política do neoliberalismo, o segundo (Lula), com a missão logística do Estado" (Cervo \& Bueno, 2011: p. 525). Assim, segundo Cervo, o governo sob o comando do PSDB priorizou relações com países desenvolvidos, em especial com os EUA, "de forma subserviente"; teve postura idealista nos fóruns multilaterais; não aproveitou as possibilidades de parceira com a China, a Rússia e o leste Europeu (Cervo, 2003: p. 7).

Uma corrente intermediária argumenta "que Lula seguiu os passos de FHC em algumas áreas e inovou em outras" (Vilela e Neiva, 2011: p. 73). Assim, os elementos de continuidade foram mais ou menos presentes, a depender do tema e do prisma da análise realizada. Essa é igualmente a posição de Vigevani \& Cepaluni (2007), que defendem não ter ocorrido uma ruptura expressiva entre as políticas externas dos dois presidentes, mas, sobretudo, uma mudança de ênfase:

"While there was no significant rupture from the paradigms of Brazilian foreign policy-some of the guidelines being reinforcements of actions already on course in the Cardoso administration - there was a change in the emphasis given to certain options opened previously." (Vigevani \& Cepaluni, 2007: p. 1310)

Na visão dos professores José Flavio Sombra Saraiva e Alcides Costa Vaz, o governo Lula expôs mais continuidades que mudanças em relação ao seu predecessor, tendo em vista que não houve um redirecionamento da política externa brasileira: "a história do presente já sugere que houve mais continuidade entre esses dois governos que diferenças essenciais" (Saraiva, 2014: p. 33); "there are no unprecedented, innovative features or ruptures in the foreign policy priorities defined by President Lula da Silva" (Vaz, 2004: p. 3). Por conseguinte, a singularidade da administração do PT foi sua disposição em agir, de modo mais assertivo e proativo, na defesa de seus interesses no contexto internacional, pois a maioria das frentes de ação diplomática do governo FHC foram mantidas, como a meta de obtenção de um assento permanente no Conselho de Segurança da ONU.

\footnotetext{
${ }^{112}$ Paradigmas aqui entendidos como conjuntos de conceitos e visões de mundo que formam a política externa e orientam a ação diplomática (Cervo \& Bueno, 2011).
} 
A análise minuciosa dos discursos e dos principais acontecimentos das duas gestões buscou verificar qual posicionamento teórico - de prevalência de rupturas ou continuidades entre as gestões dos presidentes Cardoso e Lula - melhor se aplicou ao caso da condução da candidatura ao assento permanente do CSNU. Uma questão que merece ser ressaltada é a impossibilidade de separar, com exatidão, a importância que o tema recebeu ao longo dos anos: se é resultado da motivação política pessoal dos governos ou se advém de conjunturas nacionais e internacionais favoráveis que reuniram momentum às negociações da reforma (Brigido, 2010).

\subsection{Critérios e parâmetros da comparação}

Em primeiro lugar, fez-se necessário determinar qual seria o recorte dado ao vasto universo discursivo dos períodos estudados. No caso mais recente, as gestões conduzidas pelos governos de Cardoso e de Lula, escolheu-se basear a análise, no que tange ao seu plano discursivo, prioritariamente, nos pronunciamentos realizados pelo Brasil nas aberturas das sessões ordinárias da AGNU. A decisão justificou-se por serem momentos de destaque para o governo brasileiro, em que suas preleções tinham grande ressonância no contexto internacional, servindo como representações daquilo que era prioritário à política externa brasileira (Silva 2009; 2010), conforme atestou o chanceler da Era Cardoso:

Os discursos no debate geral da Assembleia têm sido sempre aproveitados pela diplomacia brasileira para fazer uma apresentação das suas grandes linhas de política externa - e ocasionalmente de política interna - à comunidade internacional e para tratar dos temas da agenda política mundial que o país considera mais relevantes. (Lampreia, 1999: p. 332)

A coincidência histórica de tanto o governo de FHC quanto o de Lula terem exercido dois mandatos presidenciais sucessivos, permanecendo, cada um, oito anos no poder, duplicou o número de discursos de cada presidente, aumentando a incidência de manifestação, e igualou o universo de cada governante. Essa fonte primária discursiva foi complementada com entrevistas, comunicados, declarações e artigos tanto dos presidentes quanto de seus chanceleres e demais formuladores e implementadores da política externa brasileira, aproveitadas para adensar a análise e explanar eventuais lacunas interpretativas.

Para o período da candidatura brasileira ao Conselho Executivo da Liga das Nações, não seria possível utilizar idêntico recorte, tendo em vista a tradição dos discursos no início das 
sessões ordinárias da Assembléia Geral ainda não existir. Considerando que a duração da campanha na década de 1920 foi significativamente mais curta que a do momento posterior mais recente, sendo o primeiro recorte de seis anos e o segundo de dezesseis anos, para melhor embasar o pleito da Primeira República foram objeto de análise todos os documentos - a que se logrou obter acesso - em que os representantes brasileiros trataram do tema. Assim, estudaramse as comunicações internas do Itamaraty com a delegação do Brasil junto à SdN, com suas embaixadas, pronunciamentos brasileiros em várias instâncias da Liga, relatos de autoridades estrangeiras, entre outros documentos.

Os elementos encontrados nos discursos foram categorizados para facilitar a identificação e a análise das semelhanças presentes dos diferentes momentos. O primeiro critério é o do argumento utilizado para embasar a reforma. Como ela foi justificada? Por que seria necessária? O segundo apresentou as deficiências e as ameaças identificadas na atuação da Liga e da ONU, em especial nos órgãos responsáveis pela manutenção da paz e da segurança mundiais. O terceiro critério elencou as credenciais do Brasil que justificam que o país ascenda à posição de maior destaque na configuração de poder mundial. O quarto contabilizou as menções à temática da reforma das Nações Unidas e do CSNU, para estimar a importância concedida à questão por meio da sua reiteração no plano discursivo.

Além do plano discursivo, o estudo buscou identificar as estratégias empregadas pelo governo brasileiro em prol da candidatura, como as diferentes linhas de ação orquestradas pelo Ministério das Relacões Exteriores, aliadas às gestões diplomáticas presidenciais na consecução de apoio junto a outros governantes. A compreensão da evolução do contexto internacional no decorrer dos anos estudados foi primordial, considerando que a candidatura brasileira sofreu restrições e influências dos outros atores envolvidos, do tratamento auferido ao tema pela comunidade internacional e dos contextos interno, regional e organizacional.

\subsection{Análise comparativa da candidatura empreendida por Cardoso e por Lula}

A perspectiva analítica que pareceu melhor aplicar-se ao posicionamento brasileiro diante da reforma do Conselho foi a de autores, como Vaz (2004) e Vigevani \& Cepaluni (2007), que defendem não ter ocorrido uma ruptura expressiva entre as políticas externas dos presidentes, mas, sobretudo, uma mudança de ênfase: 
(FHC) wanted a permanent seat on the UN Security Council, but not enough effort was put into this objective by Brazilian diplomacy. Cardoso reached the point of declaring that he would prefer deepening regional integration and being part of the G-7 to a seat on the Security Council.

(Lula's) Minister Celso Amorim firmly expressed the country's wish to obtain a permanent seat on the Security Council. The efforts put into this objective were considerable. Brazil's mission to Haiti is an attempt to prove to the international community that the country is ready to be a permanent Council member. (Vigevani \& Cepaluni, 2007: p. 1322)

A atitude prevalecente na Era Cardoso apresentou a candidatura de forma cautelosa. $\mathrm{O}$ presidente e o chanceler afirmavam que o país não se mobilizava em uma campanha, mas se mostrava apto a assumir essa responsabilidade, caso fosse escolhido para exercer tal função em nome da América Latina (Barreto, 2012a). Paulo Roberto de Almeida observou que o país se comportou, nesse período, como "candidato não insistente" (Almeida, 2004: p. 166). Isto se deveu, principalmente, em razão do relacionamento com a Argentina, percebido como prioritário, e com a qual não se desejava criar uma linha de atrito. Cardoso chegou a declarar que, entre uma cadeira no Conselho e a amizade com a Argentina e os demais vizinhos, escolhia a segunda opção (Cardoso, 2006). As alterações da ênfase concedida à candidatura durante a gestão de FHC explicam-se, igualmente, pelos efeitos da crise financeira mundial e pelo fim do momentum favorável à reforma no âmbito da ONU. Dessa forma, a questão da reforma do Conselho recebeu maior destaque no início do governo, com auge em 1997, perdeu espaço nos anos seguintes, até praticamente sumir da agenda, em 1999-2000, e voltou timidamente ao discurso, em 2001 (Brigido, 2010).

O matiz auferido ao tema sob o comando de Lula foi pró-ativo e enérgico. Amorim acreditava que o prestígio advindo da participação do Brasil como membro permanente do Conselho seria "compensação suficiente" a todos os custos de empreender a campanha e às responsabilidades que esta condição acarretaria ao país. Amorim (1995) afirmou que o tipo de prestígio que interessava ao Brasil alcançar com a cadeira no Conselho era aquele que ampliaria a capacidade do país de zelar pelos seus interesses nacionais. O chanceler definiu sua concepção de prestígio como "o reconhecimento da capacidade de participar e, logo, exercer influência sobre o processo de tomada de decisões nas discussões sobre os principais tópicos da agenda internacional" (Amorim, 1995: p. 13).

Um dos principais custos percebidos por Cardoso como decorrentes da persecução da 
meta de obter um assento permanente era o desgaste nas relações com os países vizinhos latinoamericanos, especialmente com a Argentina (Sardenberg, 2010). O governo Lula não compartilhava dessa percepção e empregou iniciativas para obter apoio dos países da região. Ao ser questionado sobre o custo político junto à Argentina e ao México de defender a candidatura brasileira, Amorim "afirmou que não achava que houvesse, pois esses países sabiam que o tema era antigo" e que "o Brasil atuava em muita coordenação com os outros países, consultando-os em assuntos importantes, e que se viesse a ser membro permanente o Brasil iria consultar ainda mais" (Barreto, 2012b: p. 469).

No que tange ao plano discursivo, o levantamento dos elementos encontrados nos pronunciamentos demonstrou semelhanças entre as conduções da política brasileira para a obtenção de assento permanente no Conselho dos presidentes em questão. Embora tivessem sido movidos por razões políticas diferenciadas e por uma infinidade de acontecimentos únicos, ambos os governos mencionaram, reiteradamente, esse tema em seus discursos, nas sessões ordinárias da AGNU e utilizaram-se, por vezes, de argumentos similares.

A necessidade de auferir maior representatividade ao Conselho foi o elemento mais citado, estando presente na grande maioria dos pronunciamentos, seguido pelo apelo em conferir maior eficácia e legitimidade às ações emanadas do CSNU. As deficiências da Organização elencadas pelos governos de Cardoso e de Lula foram similares, assim como as ameaças advindas da incapacidade em reformá-la. Os principais riscos alegados à atuação da ONU e do Conselho de Segurança foram anacronismo, morosidade, falta de credibilidade, inação, incapacidade de gerar consensos, obstrucionismo e excessiva politização. No que se refere às credenciais brasileiras para ocupar papel de maior destaque no contexto mundial, houve menos semelhanças, inclusive por serem elementos que refletiam diferenças de prioridades de política externa e mudanças conjunturais, tanto internas quanto internacionais.

As principais credenciais elencadas pelo governo Cardoso foram: o amadurecimento da democracia; a modernização da economia; a dimensão do mercado interno; a capacidade de atração de investimentos; a diversidade interna (multiculturalismo); as iniciativas de desarmamento; o valor relativo do país; o histórico de seu comportamento internacional pacifista. O governo Lula, por outro lado, enfatizou a capacidade de atuação global do Brasil com os seguintes elementos: os contatos com o mundo árabe; os esforços de paz no Haiti; o 
fortalecimento dos vínculos com a África; a atuação do IBAS, do G-20 e dos BRICS; o aprofundamento da integração com os países latino-americanos; a participação brasileira nas negociações de segurança no Oriente Médio et alii.

Um argumento que merece ser analisado em detalhe é o da representação regional. $\mathrm{O}$ governo Cardoso introduziu o Brasil como representante da América Latina no discurso proferido por Lampreia, na 52 ${ }^{\mathrm{a}} \mathrm{AGNU}$, em 1997. Esse pronunciamento deve ser interpretado no contexto de intensificação dos debates sobre a reforma, suscitado pela convergência de várias iniciativas, em especial do Plano Razali, que previa a concessão de uma cadeira permanente à América Latina e ao Caribe. O discurso de Lampreia, ao afirmar que o país ocuparia a vaga em representação da região, fazia referência à proposta do embaixador malásio e não forneceu elementos suficientes para sustentar interpretações amplas de que o governo Cardoso se utilizou do argumento da representação regional. Corrobora essa interpretação o fato de ter sido a única menção a essa retórica em todas as fontes consultadas.

A questão de se o governo Lula empregou a linha argumentativa de ser o representante da América Latina e do Caribe no Conselho é, igualmente, objeto de controvérsias. O trecho extraído do pronunciamento do presidente perante a AGNU, em setembro de 2003, é frequentemente empregado para embasar a utilização desse argumento por Lula (cf. Brigido, 2010; Vargas, 2008):

O Brasil está pronto a dar a sua contribuição. Não para defender uma concepção exclusivista da segurança internacional. Mas para refletir as percepções e os anseios de um continente que hoje se distingue pela convivência harmoniosa e constitui um fator de estabilidade mundial. $O$ apoio que temos recebido, na América do Sul e fora dela, nos estimula a persistir na defesa de um Conselho de Segurança adequado à realidade contemporânea. (Corrêa, 2012: p. 841)

A pesquisa realizada por este estudo não encontrou, contudo, referências diretas a essa argumentação nos discursos analisados dos oito anos de mandato. Isso demonstra que, mesmo o pronunciamento de Lula dar margem a ser interpretado em defesa da representação regional, o fato de esta ideia não ter sido empregada em nenhum outro momento evidencia que a afirmação não foi representativa da estratégia desenvolvida pelo governo do PT. Conclui-se, assim, tanto o governo de Lula quanto o de Cardoso terem sido cautelosos no que diz respeito ao uso da região como plataforma para o país lançar-se em direção ao almejado assento permanente. Isso foi 
reforçado pela afirmação de Amorim, que defendeu os membros permanentes não representarem regiões, mas, antes, serem escolhidos por suas qualidades próprias (Barreto, 2012a):

Os membros permanentes (antigos e novos) devem sê-lo em função de seu papel na política e na paz, em nível regional e mundial. Embora a dimensão regional tenha que, de alguma forma estar presente, seria errado atribuirlhes o papel de "representantes regionais". Tal apresentação deverá continuar a dar-se, como sempre se deu, de forma eletiva, entre os membros não permanentes. (Amorim, 2011: p. 332)

A interpretação conferida por Amorim à candidatura pode ser considerada uma tentativa de superar a histórica falha na argumentação brasileira, à época da candidatura ao Conselho da Liga das Nações. Como defender ser o representante de um continente que se recusa a outorgarlhe tal representação? Ao advogar pela criação de um assento destinado ao continente americano e embasar a aspiração do Brasil a ocupar tal assento nas características próprias do país, Amorim diminuiu a importância da eventual não adesão dos países da região, ao mesmo tempo em que agiu em outras frentes, para arrecadar tais apoios. Ao comentar a falta de unanimidade quanto à candidatura brasileira na América Latina, o chanceler ressaltou que apoio unânime não havia em nenhuma região, sendo a latino-americana menos complicada que as demais, por não haver pendências militares (Barreto, 2012b).

Outro elemento que reforçou a percepção de Amorim foi o fato de as propostas apresentadas para a reforma do Conselho, como o plano Razali e o projeto de resolução do G-4, com a exceção da proposta da OUA, não obstante mencionarem a distribuição dos novos assentos do Conselho de acordo com critérios regionais, atribuírem à Assembleia Geral a escolha dos novos membros. O Brasil e a maioria dos países integrantes da ONU defendem o critério de seleção dos futuros ocupantes permanentes do Conselho ser universal e não regional. O apoio consensual da região não seria, portanto, necessário para a consecução do assento permanente, tampouco grupos ou regiões teriam o poder de "vetar" eventuais candidatos (Amorim, 2003).

Isso fica evidente não apenas no posicionamento brasileiro, mas também no dos demais países candidatos a cadeiras permanentes, como a Índia, o Japão e a Alemanha. Todos eles justificam suas aspirações com base em suas características e projeções internacionais, independentemente de, regionalmente, enfrentarem resistências. O critério regional não seria, portanto, fator decisivo nem preeminente na candidatura ou na escolha de futuros membros permanentes do Conselho. O Brasil pode ser candidato à vaga destinada à América Latina e ao 
Caribe sem que haja uma delegação dessa representação ao país, pois os países que pertencem ao Conselho exercem essa prerrogativa, defendendo visões e interesses próprios sem a obrigação nem a expectativa de representar os territórios geográficos aos quais pertencem. Evidencia-se, assim, importante distinção entre ser eleito de acordo com critérios de distribuição geográfica em representação de determinada região e ocupar a vaga no Conselho como representante de determinada região.

No que diz respeito à análise quantitativa dos discursos proferidos nas sessões anuais das Assembleias Gerais, a temática da ONU foi explicitada com significativa maior frequência pelo governo Cardoso do que pelo governo Lula. A questão da reforma do Conselho de Segurança foi, igualmente, aludida com maior incidência nos oito anos de administração Cardoso, conquanto o tema não tenha sido explicitado nos pronunciamentos da $54^{\mathrm{a}}$ (1999) e da $55^{\mathrm{a}}(2000)$ sessões da AGNU, o que não ocorreu em nenhum discurso proferido durante os dois mandatos do PT. A menor incidência do tema no recorte amostral do governo do presidente Lula deve ser interpretada, levando em consideração o contexto amplo da condução da política externa para a meta de alcançar um assento permanente no Conselho. Em alguns anos, a temática não foi extensamente abordada pelo governo Lula no discurso perante a AGNU, pois isso já ocorria em fóruns paralelos, como, por exemplo, na Cúpula do Milênio.

Outro dado importante de ser destacado é sobre quais foram os responsáveis por proferir os discursos nas aberturas das sessões da Assembleia Geral. Ao contrário do seu antecessor, que se fez representar pelos seus ministros de Estado em sete de seus oito anos de governo, Lula fez seis pronunciamentos perante a AGNU, somente tendo delegado a Amorim essa atribuição em duas ocasiões. O fato de o presidente ter comparecido pessoalmente, para realizar os discursos, pode ser um indicativo da maior importância que o seu governo atribuía ao Brasil em desempenhar papel de destaque no contexto mundial e da preeminência de que as Nações Unidas e a reforma do Conselho dispunham. Conforme Lampreia explicitou:

Após 1982, não foi raro que os presidentes brasileiros se dirigissem a Nova York com a finalidade de ocupar aquela tribuna [AGNU]. Em seu primeiro mandato, contudo, o presidente FHC sempre me concedeu o privilegio de fazer o discurso brasileiro. (Lampreia, 1999: p. 332)

Apesar de ambos os presidentes terem desenvolvido ampla diplomacia presidencial, apenas Lula usou-se de encontros bilaterais, de forma consciente e sistemática, para angariar 
apoio à causa nacional (Brigido, 2011). A questão foi tratada, conforme atestou Amorim, em grande parte dos encontros internacionais:

A reforma foi tema de conversa bilateral com grande parte dos governantes. O presidente Lula se referia a essa questão; eu próprio, nas conversas com os chanceleres, me referi constantemente a esse assunto; ele fez parte de vários comunicados conjuntos. (Amorim, 2011: p. 437)

Observou-se que, no plano discursivo, houve continuidade na argumentação esgrimida por Cardoso e por Lula, tendo a política externa brasileira mantido a defesa de tornar o Conselho mais democrático, legítimo e representativo com a criação de um assento permanente destinado à América Latina a ser ocupado pelo Brasil. Lula inovou, contudo, nas frentes de ação postas em movimento, para concretizar a ambição brasileira, pois Cardoso não priorizou o tema, obteve poucos apoios e praticamente não formou parcerias em prol da candidatura ao Conselho.

A formação de alianças foi prioridade para Amorim, expressa, inclusive, em seu discurso de posse, em 2003 (Brigido, 2010). Assim, a aliança forjada com os outros postulantes a assentos permanentes do Conselho, representada pelo G-4, a liderança assumida pelo Brasil do Comando Militar da Missão das Nações Unidas para Estabilização do Haiti (MINUSTAH) e a participação brasileira nas negociações sobre o programa nuclear do Irã, que culminou na Declaração de Teerã, de 2010, foram iniciativas inéditas, que serviram para embasar e legitimar o discurso de o Brasil ser capaz de desempenhar crescentes responsabilidades no âmbito internacional. Amorim negou, contudo, que a atuação do Brasil no Haiti tivesse relação com a aspiração do Brasil de ocupar uma cadeira permanente:

Muitas pessoas dizem que o Brasil foi ao Haiti porque quer um lugar no Conselho de Segurança. Isso é uma bobagem. É claro que se poderia dizer que todas as ações do Brasil podem, de alguma maneira, contribuir para que venhamos (ou não) a fazer parte do Conselho de Segurança, mas o nosso engajamento no Haiti não foi condicionado por esse fim específico. (Amorim, 2011: p. 57)

Houve significativa alteração de ênfase entre a gestão de Cardoso e a de Lula no tocante à condução da candidatura brasileira. O Brasil, todavia, nunca deixou de ser candidato, pois, embora os dirigentes do país, em alguns momentos, não estivessem dispostos a movimentar campanha em prol do assento, tampouco sinalizaram que o país rejeitaria tal encargo. Mesmo em conjunturas desfavoráveis ao pleito brasileiro, como no auge do imbróglio com a Argentina pela 
declaração do presidente Menem "vetando" a candidatura do Brasil, Lampreia reiterou que o país não se furtaria a exercer as responsabilidades inerentes à condição de membro permanente se a isso fosse chamado:

Defenderemos os interesses do Brasil no Conselho e lutaremos para que nossa região esteja ali plenamente representada. Não abriremos mão do que é natural, objetiva e universalmente reconhecido: que, se uma vaga permanente tiver de ser preenchida por um país latino-americano, o Brasil conta com credenciais que o habilitam legitimamente a apresentar-se ou ser apresentado para essa função. ${ }^{113}$

Conclui-se, assim, que o Brasil mudou de tônica, mas tanto o governo de Cardoso quanto o de Lula demonstraram ser do interesse do país, acima de divisões político-partidárias, ocupar destacada função na configuração da paz e da segurança internacionais. A candidatura, mantida de forma mais ou menos explícita, com intensidade distinta, corroborou a posição de autores que defendem as características da política externa de Lula terem tido início no governo anterior, de forma tímida, e sob a gestão do PT, terem atingido seu auge (Visentini apud. Brigido, 2010). Abaixo, segue tabela referente às menções à ONU, ao Conselho e às respectivas reformas ${ }^{114}$ :

Tabela número 1. Governo do Presidente Fernando Henrique Cardoso. Período de 1994 a 2002.

\begin{tabular}{|c|c|c|c|c|c|c|c|}
\hline \multicolumn{7}{|c|}{ GOVERNO FHC } \\
\hline & $\begin{array}{c}\text { Nações } \\
\text { Unidas }\end{array}$ & ONU & $\begin{array}{c}\text { Organização } \\
\text { (referente à ONU) }\end{array}$ & $\begin{array}{c}\text { Reforma } \\
\text { da ONU }\end{array}$ & $\begin{array}{c}\text { Reforma do } \\
\text { Conselho }\end{array}$ & $\begin{array}{c}\text { Conselho de } \\
\text { Segurança }\end{array}$ & Palestrante \\
\hline 1995 & 24 & 0 & 5 & 7 & 8 & 1 & Lampreia \\
\hline 1996 & 17 & 13 & 8 & 2 & 2 & 0 & Lampreia \\
\hline 1997 & 23 & 0 & 8 & 7 & 8 & 6 & Lampreia \\
\hline 1998 & 2 & 1 & 2 & 5 & 2 & 1 & Lampreia \\
\hline 1999 & 9 & 0 & 2 & 0 & $\mathbf{0}$ & 3 & Lampreia \\
\hline 2000 & 8 & 2 & 1 & 0 & $\mathbf{0}$ & 0 & Lampreia \\
\hline 2001 & 5 & 3 & 3 & 1 & 2 & 0 & Cardoso \\
\hline 2002 & 8 & 3 & 4 & 0 & 2 & 5 & Lafer \\
\hline TOTAL & $\mathbf{9 6}$ & $\mathbf{2 2}$ & $\mathbf{3 3}$ & $\mathbf{2 2}$ & $\mathbf{2 4}$ & $\mathbf{1 6}$ & \\
\hline
\end{tabular}

Fonte: Tabela elaborada pela autora. Brasília, outubro de 2013.

${ }^{113}$ LAMPREIA, Luiz Felipe. A reforma do Conselho de Segurança. Folha de São Paulo. Opinião. 31 ago. 1997. Disponível em: www1.folha.uol.com.br/fsp/1997/8/31/opinião/8.html. Acesso em: 30/09/2014.

114 Ressalte-se que não foram contabilizadas as menções à ONU quando se tratava de citações a conferências ou a cargos de funcionários. As classificações em menções que se referem ou não à reforma podem apresentar certa imprecisão, tendo em vista a contextualização dos pronunciamentos dar margem a interpretações subjetivas. 
Tabela número 2. Governo do Presidente Luiz Inácio Lula da Silva. Período de 2003 a 2010.

\begin{tabular}{|c|c|c|c|c|c|c|c|}
\hline \multicolumn{7}{|c|}{ GOVERNO LULA } \\
\hline 2003 & 5 & 9 & 2 & 2 & 3 & 0 & Lula \\
\hline 2004 & 2 & 1 & 0 & 0 & 2 & 1 & Lula \\
\hline 2005 & 6 & 0 & 4 & 0 & 4 & 2 & Amorim \\
\hline 2006 & 6 & 0 & 1 & 0 & 3 & 1 & Lula \\
\hline 2007 & 5 & 0 & 0 & 0 & 2 & 0 & Lula \\
\hline 2008 & 2 & 0 & 0 & 0 & 2 & 0 & Lula \\
\hline 2009 & 2 & 10 & 0 & 1 & 2 & 0 & Lula \\
\hline 2010 & 0 & 2 & 0 & 0 & 1 & 1 & Amorim \\
\hline TOTAL & $\mathbf{3 3}$ & $\mathbf{2 2}$ & $\mathbf{7}$ & $\mathbf{3}$ & $\mathbf{1 9}$ & $\mathbf{6}$ & \\
\hline
\end{tabular}

Fonte: Tabela elaborada pela autora. Brasília, outubro de 2013.

\subsection{Análise comparativa das campanhas para a Liga e para a ONU}

Em Era dos Extremos, Hobsbawm questiona "como comparar o mundo da década de 1990 ao mundo de 1914". O autor responde à indagação ao alegar que não é possível comparálos em termos de contabilidade histórica de "mais e menos", pois são "mundos qualitativamente diferentes em pelo menos três aspectos", quais sejam: o mundo ter deixado de ser eurocêntrico; o mundo ter-se tornado uma unidade operacional única; e terem-se desintegrado os velhos padrões de relacionamento social humano (Hobsbawm, 1995: p. 21-23). Dessa forma, o historiador britânico já havia deparado com questionamento semelhante ao que se propôs esse trabalho, e suas conclusões podem servir para auxiliar a condução desta análise comparada.

Um dos aspectos transformadores do breve século XX, mencionados por Hobsbawm, foi o declínio europeu. As duas Grandes Guerras foram o ápice da passagem do centro de poder mundial do Velho Continente para o Novo Mundo. A Liga das Nações foi incapaz de acompanhar essa transição, e sua rigidez perpetuou-a eurocêntrica em um mundo que já não mais o era, contribuindo para seu fracasso e desintegração. Não por acaso, sua sucessora, a ONU, fixou seus alicerces no âmago da principal pujança ocidental, após a Segunda Guerra, responsável por elevar o conceito de potência a um patamar sequer existente no período de hegemonia europeia dos séculos anteriores: o de superpotência. 
A fundação das Nações Unidas foi, dessarte, o marco do processo de decadência europeia e de soerguimento de nova ordem liberal, institucional, regimentada por Bretton Woods e patrocinada pelos EUA (Ikenberry, 2001). O primeiro elemento de mudança na comparação dos pleitos brasileiros em prol de cadeiras permanentes nos Conselhos da SdN e da ONU consistiu, portanto, na alteração da ordem mundial sobre a qual a campanha se desenvolveu. O contexto internacional passou de eminentemente europeu, com resquícios de alianças e práticas diplomáticas que se remetiam ao ordenamento mundial do século anterior, o Concerto Europeu, para uma estrutura organizacional em que a presença e a importância dos EUA eram marcantes.

O Brasil, na candidatura de 1921 a 1926, buscou obter, por meio de ações orquestradas pelo Itamaraty, o apoio dos Estados Unidos para ocupar a vaga deixada pela potência norteamericana no Conselho. O valor dessa recusa não foi um fator preponderante nas causas que levaram o Brasil a não conseguir o assento permanente, até mesmo devido ao fato de os EUA não serem membros da Liga. Na curta campanha esboçada pelo Brasil em 1944 e 1945, o elemento que mais valeu a favor do país, levando o período a ser considerado aquele em que o Brasil esteve mais próximo de tornar-se o sexto membro permanente, foi, justamente, o respaldo dos Estados Unidos ao então "bom vizinho" latino-americano.

No pleito mais recente, o Brasil buscou receber semelhante aprovação, mas as réplicas foram ambíguas e efusivas, sendo a ausência de apoio dos EUA ao pleito brasileiro um dos principais obstáculos à concretização da meta de sentar-se em condição de igualdade com as grandes potências. Houve, portanto, um incremento exponencial da importância do apoio norteamericano nos cálculos estratégicos para a consecução desse desígnio da política externa brasileira, reflexo da transição ocorrida, no breve século XX, do eurocentrismo para o americanismo.

Um elemento de continuidade entre as candidaturas nos diferentes períodos estudados foi o não engajamento da opinião pública brasileira. A indiferença de grande parte da população à pretensão do Brasil na Liga foi reiteradamente citada em análises históricas (Garcia, 2006; Santos, 1996, Rodrigues, 1995) e fontes primárias da época, como ilustra o relatório do embaixador britânico no Brasil, Sir Beilby Alston, destinado a Chamberlain:

As for the public opinion, it can hardly be said to exist in Brazil, at least as regards questions of external affairs. The enthusiasm and passions of the people are reserved exclusively for matters of internal politics and 
municipal scandals, while it is almost impossible to get the average cultured Brazilian to discuss any question other than the most trivial. As for the average Deputy, he is just vaguely aware that other countries do exist outside the confines of the American continent. This state od affairs tends to strengthen very considerably the autocratic powers wielded by the President, and even a man of lesser obstinacy would have little difficulty in imposing his will in this respect. ${ }^{115}$

$\mathrm{O}$ detabe sobre a pretensão brasileira na $\mathrm{SdN}$ era restrito à mídia impressa e instrumentalizado para atacar ou enaltecer o presidente, sem haver interesse genuíno pelas questões genebrinas. As demontrações de apoio popular que Pacheco e Bernandes receberam pelo veto do Brasil à Alemanha foram forjadas pelo próprio governo. O único momento em que se pode afirmar ter sido desperto o interesse da população pelas ações do país na Liga foi quando ocorreu a retirada do Brasil daquela organização. Isso representaria um ponto de aproximação entre os dois períodos, haja vista que, contemporaneamente, embora a candidatura do Brasil ao Conselho de Segurança tenha sido objeto de atenção, a imprensa não logrou despertar o interesse da sociedade:

Uma das marcas da nova candidatura brasileira ao Conselho de Segurança é que ela vem sendo apresentada à sociedade como se fosse produto de um "consenso" em torno da defesa do "interesse nacional". E essa mesma sociedade tem demonstrado, se não apoio, ao menos indiferença para um tema que implica, de fato, ônus financeiro e militar para o país, como se a candidatura brasileira fosse tão "natural" aos olhos do público doméstico como o deveria ser aos dos outros países. (Silva, 1998: p. 153)

No que tange à argumentação empregada pelo Brasil na década de 1920, segundo Seitenfus (1995), o país modificou seus argumentos para justificar sua candidatura ao longo do tempo e de acordo com as circunstâncias. A base do discurso brasileiro consistiu, contudo, em advogar pela regionalização da composição do Conselho com a representação das Américas, para a preservação do caráter universal da $\mathrm{SdN}$ e, assim, da sua legitimidade. Melo Franco, ao afirmar não dever ser suprimido o assento permanente no Conselho que o pacto da $\mathrm{SdN}$ conferia ao continente americano pela ausência dos Estados Unidos ${ }^{116}$, o representante brasileiro distorcia o pacto, pois o assento permanente destinava-se aos EUA e não ao continente americano. Os critérios existentes para preenchimento das cadeiras permanentes do Conselho da Liga

\footnotetext{
115 Alston a Chamberlain, confidential, Annual Report, 1927. FO 371/12744, rolo 36.

${ }^{116}$ Carta de Afrânio de Mello Franco dirigida a Robert Cecil, Léon Bourgeois e Branting, Genebra, 20/09/1923, confidencial. AHI, Liga das Nações, Delegação do Brasil, ofícios recebidos, 1922-1923, 274/2/1A.
} 
baseavam-se, principalmente, no poder militar e na capacidade econômica, por isso apenas as grandes potências vencedoras da Primeira Guerra foram contempladas. A repartição geográfica dos assentos preconizada, em diversos momentos, pela Assembleia Geral da $\mathrm{SdN}$, só se referia aos assentos temporários (Santos, 1996).

$\mathrm{Na}$ época da fundação da ONU, o critério de escolha dos membros permanentes do Conselho de Segurança foi embasado no poder militar, mas com a ponderação de uma perspectiva regionalista. Churchill foi o impulsionador desse regionalismo, pois considerava que "somente os países cujos interesses fossem afetados teriam disposição para interpor-se com energia na resolução de uma controvérsia" (Garcia, 2012: p. 34). Assim, a representação regional seria uma maneira de engajar os países a agir de forma mais enérgica, a fim de lidar com o fardo de manter a paz e a segurança mundiais, tornando o Conselho mais eficiente.

$\mathrm{Na}$ campanha recente, o Brasil justificou sua candidatura ao Conselho centrado no argumento de que o órgão não representa a atual distribuição do poder mundial, perpetuando a configuração anacrônica do pós-Segunda Guerra. A admissão brasileira a um assento permanente daria maior representatividade geográfica, política e econômica ao Conselho, aumentando, consideravelmente, sua legitimidade perante as demais nações. O argumento de tornar o Conselho de Segurança mais representativo da região, apresentado na década de 1990, diferiu significativamente do utilizado na década de 1920.

A campanha para a cadeira permanente no Conselho da Liga foi embasada na argumentação de o Brasil ter um mandato "mandato implícito", autorizando-o a ser o "porta-voz da consciência pan-americana" no Conselho ${ }^{117}$. Nota-se que o valor do argumento da representação regional foi consideravelmente superior ao apresentado nos pleitos mais recentes, em que tal linha argumentativa foi evitada ou tangenciada nos pronunciamentos oficiais. Apesar de, hodiernamente, preconizar-se a distribuição das cadeiras do Conselho de acordo com critérios de distribuição regional, o Brasil e os demais candidatos embasam as argumentações em suas capacidades de projeção global e suas características nacionais.

Outra distinção no argumento da representação regional apresentado nos anos 1920 em relação ao recente é a abrangência territorial que o Brasil almejava representar. Como os EUA estavam fora da Liga, os discursos brasileiros naquele organismo defendiam ser o país o

\footnotetext{
${ }^{117}$ Cunha a Marques, telegrama, Paris, 17/01/1920. AHI, 227/3/6.
} 
representante das "Américas". Atualmente, as duas menções sobre o país ocupar a vaga destinada à região, com base em propostas de distribuição geográfica dos novos assentos permanentes, referem-se à representação da América Latina e do Caribe.

Notou-se que a adesão regional ao pleito brasileiro foi outro ponto de distanciamento entre as candidaturas de outrora e hodierna. Na década de 1920, o país não detinha o apoio declarado da maioria dos Estados latino-americanos nem sequer desenvolveu uma política consistente em prol de obtê-lo. Como pôde ser examinado no capítulo 1, as estratégias implementadas pela diplomacia brasileira, sob o governo de Artur Bernardes, a favor de alcançar a cadeira permanente, como, por exemplo, a missão itinerante de Raul Fernandes, foram direcionadas às capitais europeias e, por vezes, aos EUA. Os vizinhos latino-americanos eram percebidos pelos dirigentes brasileiros de forma depreciativa e não mereceram a devida atenção no plano de consecução do pleito nacional. Isso refletia o fato de o valor da região para a política externa brasileira, naquele período, ser periférico. Os principais parceiros comerciais e o foco da atenção internacional do país residiam no hemisfério norte e oscilavam entre os EUA e a Europa.

Nada mais distante do que a realidade do período mais recente em que ambas as administrações de Cardoso e de Lula conferiam primazia às relações com os vizinhos, em especial com a Argentina. É comumente aceito que a gestão de Lula acentuou a importância concedida à região, enfatizou a cooperação Sul-Sul, aprofundou a integração entre os países latino-americanos e criou novas iniciativas de concertação político-econômica regionais. Todavia, a importância que o governo Cardoso atribuiu ao Mercosul e ao relacionamento com a Argentina foi igualmente significativa. Portanto, um elemento de ruptura entre os pleitos estudados foi o valor relativo da América Latina tanto na orientação da política brasileira quanto na consecução das candidaturas aos assentos permanentes.

Tendo em vista que a candidatura brasileira à Liga e a curta campanha desenvolvida à época da fundação da ONU nasceram das iniciativas do Chile e dos EUA, respectivamente, um elemento causal que pode ser delineado para o pleito nacional foram as influências recebidas de outros Estados. Se, no caso da campanha da década de 1920, esboçarmos uma análise contrafactual, é provável chegarmos à conclusão de que a candidatura seria iniciada de qualquer forma, tendo em vista a relevância que veio a adquirir na política externa nacional. De outro modo, se a tarefa de iniciá-la tivesse ficado a cargo do Brasil, possivelmente, seu advento não 
teria ocorrido no governo de Epitácio Pessoa, mas no de seu sucessor, Artur Bernardes. Essa análise demonstra que a importância do aporte recebido dos outros Estados não foi preponderante como causa impulsionadora do pleito de outrora.

No que tange à campanha velada, realizada na década de 1940, tendo em vista o governo brasileiro não ter tido, pelo menos oficialmente, conhecimento da iniciativa de Roosevelt quando da opção pela candidatura indireta, a ausência da participação norte-americana não teria, provavelmente, causado modificações significativas nas ações empreendidas em prol de tornarse o sexto membro permanente do Conselho de Segurança. Finalmente, no caso da campanha recente, a pretensão foi principiada por Celso Amorim nos últimos meses da gestão do presidente Itamar Franco, sendo, portanto, seu lançamento iniciativa do país, não tendo recebido a influência de outros Estados nesse primeiro momento.

Mais importante que a influência particular de um ou outro Estado, a conjuntura internacional exerceu significativa pressão nas causalidades que contribuíram para a escolha de empreender essa meta da política externa. Assim, nos anos 1920, após a Primeira Guerra, com o Brasil tendo sido o único latino-americano a participar do conflito, criou-se uma atmosfera favorável ao país, o que contribuiu para a supervalorização da capacidade brasileira de agir no plano externo. Posteriormente, o contexto de disputas cada vez mais acirradas em torno dos assentos rotativos do Conselho Executivo da Liga e a adoção de regras que impediriam a reeleição sucessiva dos membros temporários foram elementos presentes nas relações causais que levaram os representantes brasileiros a ter sugerido que o país implementasse uma campanha para obter um assento permanente.

Hodiernamente, não foi por coincidência que, apesar de a reforma do Conselho ter sido objeto de reiteradas menções dos representantes brasileiros ao longo dos anos de existência da ONU, a candidatura tivesse sido oficialmente lançada meses antes da comemoração do cinquentenário da Organização. Os momentuns gerados pelos contextos internacionais tiveram expressiva influência sobre as decisões de lançar, renovar ou abrandar a pretensão brasileira. Dessa forma, o contexto de crise financeira internacional, existente na virada do século XX, durante a gestão de Cardoso, corroborou para que o pleito fosse secundarizado. De forma análoga, eventos internacionais, como a guerra do Iraque, a Cúpula do Conselho de Segurança, os lançamentos dos projetos de reforma dos secretários-gerais da ONU, a comemoração do 
sexagenário da Organização, retomaram e escalaram os esforços brasileiros empreendidos a favor desta meta.

O contexto interno também tem participação nas relações causais e motivacionais responsáveis pela escolha e pela consecução desse intento da política externa brasileira. $\mathrm{O}$ estudo realizado nesta dissertação apreendeu que a importância da situação interna foi mais expressiva nos anos 1920. Como elucidado anteriormente, no capítulo 1, a iniciativa de conduzir a campanha em prol de um assento permanente no Conselho da SdN surgiu, em primeiro lugar, da ideia do representante chileno, e, em segundo, como tentativa de solucionar a possível perda do assento temporário usufruído pelo país. Contudo, a explicação para a importância que essa aspiração tomou em 1926 reside no contexto de turbulência interna confrontado pelo país. A aposta no "tudo ou nada" para conseguir uma cadeira permanente no Conselho, fator que agravou a crise de março de 1926, pode ser entendida como parte da estratégia de Bernardes para desviar a atenção dos problemas internos enfrentados por sua gestão.

Na condução da candidatura realizada por Cardoso, a estabilização monetária do país, a redemocratização, o ganho de estabilidade financeira e o crescimento da economia foram elementos reiterados pelo dirigente que contribuíram para o Brasil julgar-se apto a reivindicar uma participação mais preeminente nas atividades internacionais. No governo Lula, as causalidades internas podem ser encontradas principalmente nos critérios auferidos pelos programas sociais implementados pelo seu governo.

Outro elemento causal relevante diz respeito à percepção que o Brasil tem de si, à sua autoimagem (Silva, 1998). Esse tema comporta uma análise ampla, com definições e terminologias próprias que fogem ao escopo deste trabalho. Ressalte-se, porém, o acumulado histórico da diplomacia brasileira (Cervo, 2008), ou o "substrato normativo" (Vargas, 2008) de conferir ao Brasil uma posição altiva no âmbito internacional, percebendo-se, desde os tempos do Império, como um país, único e especial, primus inter paris (Garcia, 2006). Apesar de momentos de hiato, esse traço da política externa brasileira fez-se presente nas candidaturas aos Conselhos da Liga e da ONU.

Uma ressalva faz-se, contudo, necessária. O acumulado histórico da diplomacia brasileira não deve ser interpretado como uma continuidade do pensamento diplomático stricto sensu. A formulação das ações externas do Brasil, como as realizadas no âmbito da Liga, por exemplo, 
foram idealizadas por membros da elite política brasileira, não por diplomatas, tendo em vista que o Ministério dos Negócios Estrangeiros ainda não dispunha de um quadro profissional bem constituído (Garcia, 2006). Dessa maneira, o acumulado histórico da diplomacia nacional referese a traços de continuidade dos formuladores da política externa brasileira em sentido amplo, que antecederam e sucederam a consolidação de uma classe diplomática formalmente instituída.

A personalidade dos homens de Estado foi um vetor que não pode ser menosprezado. Nos anos 1920, a polarização em torno das visões de mundo de Bernardes e Pacheco exerceram influência preponderante, senão majoritária, na iniciativa de alçar o Brasil ao posto reservado às grandes potências. Na campanha ao Conselho da ONU, as percepções de Amorim foram fundamentais na elaboração e na consecução dessa meta, tendo sido o chanceler o responsável por convencer o presidente Lula da justeza e da importância de tal aspiração, conforme se subentende na narração de Amorim sobre que o presidente não apenas aceitou que o tema fosse tratado, como também passou a inseri-lo por conta própria nos encontros oficiais (Amorim, 2011).

Como não poderia ser diferente, a questão de quais foram as causas e as motivações do Brasil para insistir em empreender tais candidaturas remete-se à busca por prestígio, que foi a grande força motriz na candidatura empregada no início do século XX. Pode-se inferir que, no primeiro período analisado, os dirigentes do país eram motivados por uma definição superficial e ingênua de prestígio. Movidos por delírios de grandeza, visavam afirmar-se perante os demais países, impondo sua presença com ameaças e sem contrapartidas consistentes. Por mais que o Brasil se esforçasse para estar presente às instâncias deliberativas da Liga, sua participação carecia de substância. Dessa forma, na Primeira República, o Brasil buscava prestígio perante seus pares internacionais para aplacar pressões políticas internas e servir como elemento de coesão nacional.

Para Amorim, a busca por prestígio representava o desejo de participar dos processos decisórios mundiais, pois a presença do Brasil no Conselho, como membro permanente, contribuiria, de forma única, na resolução de conflitos. Essa busca foi acompanhada, no governo Lula, de ações que embasaram a capacidade do país de assumir tal encargo. Conforme afirmou Cervo, o governo Cardoso não se engajou, ativamente, na transformação da sociedade internacional. O presidente acreditava ser suficiente ao Brasil participar dos fóruns multilaterais 
com as regras estabelecidas pelas grandes potências, sem ascender à condição de formulador do ordenamento internacional. Se tal análise é correta, mesmo não tendo sido encontrada uma definição da busca por prestígio perseguida pelo governo Cardoso, infere-se, no que tange à candidatura ao Conselho, que foi limitada, aproximando-se mais da gestão de Epitácio Pessoa, na qual prevalecia certa satisfação com o status internacional gozado pelo país. 


\section{CONCLUSÃo}

Esta dissertação moveu-se no objeto da busca do Brasil por um assento permanente no inner sanctum da $\mathrm{SdN}$ e da $\mathrm{ONU}$, cujas cadeiras permanentes são, tradicionalmente, de preenchimento exclusivo das grandes potências mundiais. Caberia, portanto, o questionamento: far-se-ia o país jus a essa posição? Costuma ser aceito que o status de potência mundial depende de um conjunto de fatores objetivos, relacionados à capacidade militar, econômica e tecnológica de um país, e de fatores subjetivos, referentes ao reconhecimento desse status pelas demais grandes potências e pela comunidade internacional. De acordo com esses critérios, segundo alguns autores, o Brasil não poderia ser considerado um global power, pois ainda the faltaria o preenchimento de condições tanto objetivas quanto subjetivas (Almeida, 2010: p. 160).

A capacidade de angariar apoio junto a diversos países, observada nos oito anos do governo Lula, expressa em inúmeros communiqués bilaterais, deveu-se mais à capacidade de projeção internacional do presidente, aliada a vasto engajamento do Itamaraty, do que à transformação da realidade estrutural do país de modo a torná-lo grande potência. O desempenho da diplomacia nacional, tanto a exercida pelo presidente quanto a conduzida pelo Ministério das Relações Exteriores, firmou-se como o "campo mais bem-sucedido do governo Lula, com o país recuperando uma ação de grande intensidade e alcance planetário" (Vizentini, 2013: p. 118; Gonçalves, 2011: p. 13):

Brazil's 'diplomatic GDP' is greater than its economic GDP, and the later is certainly greater than its 'military $G D P^{\prime}$ ', in other words, its capacity for projecting power abroad. Indeed, Brazil's influence in diplomatic negotiations is more important than its actual presence in the world, as compared, for instance, to its participation in trade and finantial flows. (Almeida, 2010: p. 164)

O crescimento da economia brasileira, que, em 2010, último ano compreendido por este estudo, posicionou-se como a $7^{\mathrm{a}}$ maior do mundo ${ }^{118}$, deveu-se, em grande medida, a conjunturas favoráveis do mercado mundial de commodities, à valorização do real e não traduziu, com precisão, o ambiente econômico do país. Apesar do inegável sucesso das políticas sociais

\footnotetext{
${ }^{118}$ RODRIGUES, Lorenna. Brasil já é a $7^{\mathrm{a}}$ maior economia do mundo, diz Mantega. Folha de São Paulo. Mercado. 03 mar. 2011. Disponível em: http://wwwl.folha.uol.com.br/mercado/2011/03/883828-brasil-ja-e-a-7-maioreconomia-do-mundo-diz-mantega.shtml. Acesso em: 25/08/2014.
} 
implantadas pela gestão do Partido dos Trabalhadores, que extraíram milhões de brasileiros da miséria extrema ${ }^{119}$, as deficiências sociais em áreas estruturais, como saúde, educação e segurança pública, persistem retratadas em índices internacionais ${ }^{120}$.

Se, por um lado, falta ainda ao Brasil o preenchimento de critérios objetivos para ser classificado como potência mundial, por outro, pode-se afirmar que o país preenche os requisitos materiais para ser considerado um líder regional. Conforme foi reiteradamente explicitado nos pronunciamentos dos representantes brasileiros, em ambos os períodos históricos analisados, mas, sobretudo, no mais recente, o país, que é o quinto maior do mundo em dimensão territorial, um dos seis maiores mercados internos do planeta, a maior economia e a mais avançada base tecnológica da região. Dessa forma, estariam preenchidas as condições objetivas necessárias para justificar a pretensão de ser o "representante da América Latina" (Visentini, 2013; Almeida, 2010).

Por outro lado, a questão de o Brasil dispor do critério subjetivo necessário à concretização de seu pleito é controversa. À época da Liga, o reconhecimento da capacidade do país de desempenhar papel de destaque na manutenção da paz e da segurança internacionais era restrito. O país não conseguiu o apoio entusiasta dos países latino-americanos e tampouco logrou a adesão das grandes potências da época. Conforme mencionou Hilton (2013) em sua análise sobre a candidatura brasileira conduzida nos anos 1920, se o Brasil contasse com a legitimidade de ter sido aclamado o representante da América Latina por seus vizinhos, sua imparidade militar e econômica perante as grandes potências poderia ter sido dirimida.

$\mathrm{Na}$ candidatura impulsionada nos anos 1990, a projeção internacional do Brasil é significativamente maior que outrora, e as articulações da diplomacia presidencial de Lula conseguiram receber manifestações de apoio ao pleito brasileiro de inúmeros países. Percebe-se, assim, estar o país mais perto de preencher o critério subjetivo de reconhecimento de seu status de global player conquanto ainda longe de alcançar um consenso em torno de sua candidatura. A

\footnotetext{
${ }^{119}$ REDAÇÃO. Brasil Sem Miséria retira 22 milhões da pobreza extrema. Carta Maior. 19 fev. 2013. Disponível em: $\quad$ http://www.cartamaior.com.br/?/Editoria/Politica/Brasil-Sem-Miseria-retira-22-milhoes-da-pobrezaextrema/4/27424. Acesso em: 25/08/2014.

120 "Brasil atingiu, em 2010, menor patamar histórico de desigualdade de renda. Apesar do bom resultado a desigualdade de renda medida pelo índice de Gini no Brasil ainda está abaixo dos padrões dos países de primeiro mundo. $\mathrm{O}$ índice de Gini brasileiro está em 0,5304, acima do de 0,42 dos Estados Unidos - quanto mais próximo de 1, pior a desigualdade." RITTO, Cecília. Brasil atingiu, em 2010, menor patamar histórico de desigualdade de renda. Veja. Brasil. 03 maio. 2011. Disponível em: http://veja.abril.com.br/noticia/brasil/brasil-atingiu-em-2010-menorpatamar-historico-de-desigualdade-de-renda. Acesso em: 25/08/2014.
} 
oposição de nações latino-americanas, como México, Argentina, Colômbia, não foi superada, mas tampouco se caracteriza como obstáculo intransponível, uma vez que a escolha dos futuros membros deverá dar-se por sufrágio universal na Assembleia Geral da ONU. Mesmo assim, o apoio dos países da região poderia ter contribuído na aprovação dos EUA e da Rússia à pretensão brasileira. Conforme elucidado no capítulo 2, em visita ao Brasil, em julho de 1995, o adjunto do Departamento de Estado norte-americano, Strobe Talbott, afirmou que os EUA referendariam o pleito brasileiro se o país obtivesse o apoio da comunidade latino-americana. De forma análoga, em novembro de 1997, a Rússia defendeu a concessão de um assento permanente no Conselho destinado à América Latina, cujo ocupante deveria ser definido pelos próprios latino-americanos (Arraes, 2005).

Apesar das qualitativas transformações alcançadas pelo Brasil no último século, que o diferenciam do país agrário do início do século $\mathrm{XX}$, as chances de realização da ambição brasileira de alçar-se ao clube das grandes potências, embora já não façam jus a ser chamadas de desmedidas, como foi a ambição à Liga, continuam remotas. A obrigação dada pela Carta da ONU de receber a aprovação de todos os membros permanentes faz que a consecução de qualquer reforma dos assentos do Conselho seja improvável no curto e médio prazos. Se, por um lado, o arranjo institucional dos países candidatos, o G-4, ajudou a conferir maior visibilidade ao pleito, por outro, possivelmente, acrescentou mais uma dificuldade à entrada brasileira, pois tanto o Japão quanto a Índia possuem a obstinada censura, mesmo que velada, da China (Malik, 2005).

É consensual entre os autores que se dedicaram ao pleito brasileiro da década de vinte que suas motivações estivessem mais estritamente ligadas a questões de prestígio, tendo em vista as visões de mundo e as personalidades dos formuladores da política externa brasileira daquela época, Bernardes e Pacheco. Outro fator motivador da candidatura de outrora foram as condições de política interna, tendo em vista ter sido um dos períodos mais conturbados da história do país e o governo de Bernardes ter tido, praticamente, toda sua extensão temporal sob as limitações de um estado de sítio ininterrupto.

Análise semelhante não comporta o período mais recente, em que as motivações da candidatura tiveram grande influência dos movimentos externos de reformulação da ONU, no âmbito do cinquentenário da Organização, aliadas às ambições do país de reinserir-se mais 
ativamente no sistema internacional como potência emergente. A candidatura atual relaciona-se com as iniciativas brasileiras de passagem de um regional power para um global player, como são exemplos suas tentativas de mediar conflitos no Oriente Médio, as formações dos BRICS, do IBAS e as participações do país no G-20.

Por fim, cabe ponderar sobre o quadro mais amplo de reforma da ONU. A validade desta organização no século que se inicia está intrinsicamente relacionada à capacidade dos governos de ceder e negociar alternativas viáveis de renová-la. O caráter político e interestatal da estrutura decisória do sistema onusiano, em que as ações e as decisões dependem do acordo majoritário, se não consensual, dos Estados, tem-se mostrado insuficiente diante da complexidade de que se revestem as questões internacionais contemporâneas. A inépcia para obter avanços no processo negociador da reforma do Conselho, vigente há quase trinta anos, é um retrato da insuficiência da abordagem estatocêntrica para responder aos desafios com que se confrontam a ONU e a humanidade (Weiss, 2009).

A arena internacional é caracterizada, portanto, pela relação dialética entre problemas transnacionais que exigem cooperação multilateral e tomadores de decisão com escopo e interesses restritos aos das suas fronteiras nacionais. Isso tem levado autores a prever duas possibilidades para a ONU: ou passará por uma reforma profunda que lhe conferirá maiores poderes de exercer governança global, ou haverá a falência da Organização com surgimento de novo ordenamento e consequências indeterminadas (Weiss, 2009: p. 4). Acima do interesse particular brasileiro de galgar maior participação internacional por meio de um assento permanente no Conselho, efetivar uma reforma abrangente da instância superior responsável pela paz e pela segurança mundiais é, portanto, uma responsabilidade comum, compartilhada por todos os Estados da comunidade internacional, que deveria sobrepor-se a ganhos e interesses nacionais. 


\section{REFERÊNCIAS}

\section{Documentos de Arquivos:}

\section{Arquivo Histórico do Itamaraty (AHI)}

Ministério das Relações Exteriores, Escritório Regional no Rio de Janeiro

Correspondência da Missão diplomática do Brasil em Washington:

Telegramas recebidos e expedidos: $1923-1924$ (235/3/14), 1924-1925 (235/3/15), 1926 $(235 / 3 / 10 \mathrm{~A})$

Correspondência da Missão diplomática do Brasil em Londres:

Telegramas receidos e expedidos: 1923-1926 (219/2/15), 1927-1930 (219/3/5)

Correspondência da Missão diplomática do Brasil em Paris:

Telegramas recebidos: 1920-1921 (227/3/6), 1922-1923 (227/3/7)

Telegramas expedidos: 1919-1921 (227/4/1), 1920 jan (227/3/6)

Correspondência das Delegações do Brasil junto à Liga das Nações:

Ofícios recebidos: 1920-1923 (274/2/1), 1921 (274/2/1A)

Telegramas recebidos: 1920-1924 (274/2/3).

Correspondência da Delegação Permanente do Brasil junto à Liga das Nações:

Ofícios recebidos: 1924 (274/2/5), 1925 (274/2/9), 1926 (274/2/10), 1924-1925 (274/2/11)

Despachos e telegramas expedidos: 1920-1924 (274/2/4), 1920-1924 (274/3/4), 1926 (274/3/1)

\section{Arquivo Nacional}

Divisão de Documentação Escrita, Sala de Consultas, Rio de Janeiro

Arquivos diplomáticos estrangeiros sobre o Brasil (1906-1954):

Documentos do Foreign Office sobre o Brasil: 
FO 371/04440 - rolo 17

FO $371 / 08433$ - rolo 28

FO 371/10608 - rolo 32

FO 371/11118 - rolo 33

FO $371 / 11964$ - rolo 34

FO 371/11967 - rolo 35

FO $371 / 12743$ - rolo 36

FO $371 / 12744$ - rolo 36

FO $371 / 13468$ - rolo 37

\section{Biblioteca Nacional}

Divisão de Manuscritos, Rio de Janeiro

Coleção Afrânio de Melo Franco:

Correspondências presidenciais ativa e passiva entre Artur Bernardes e Melo Franco

Recortes de jornais

Pastas sobre a Liga das Nações: 380, 484, 531e 638

\section{Arquivo online das Nações Unidas}

United Nations Official Document System (UNODS)

UNITED NATIONS. Question of equitable representation on and increase of the membership of the Security Council. General Assembly. A/48/264. 20 jul. 1993. Disponível em: http://dcuments-dds-y-un.org. Acesso em: 25/12/2013.

UNITED NATIONS. General Assembly. A/48/264. 20 jul. 1993. Disponível em: http://documents-dds-

ny.un.org/doc/UNDOC/GEN/N93/396/96/img/N9339696.pdf?OpenElement. Acesso em: $25 / 12 / 2013$. 
UNITED NATIONS. General Assembly. A/50/47. 13 set. 1996. Disponível em: http://documents-dds-

ny.un.org/doc/UNDOC/GEN/N96/240/70/pdf/N9624070.pdf?OpenElement. $\quad$ Acesso em: $28 / 12 / 2013$.

UNITED NATIONS. A more secure world: our shared responsibility. Report of the High-level Panel on Threats, Challenges and Change. A/59/565. 01dez. 2004. Disponível em: http://daccessdds-ny.un.org/doc/UNDOC/GEN/N04/602/31/PDF/N0460231.pdf?OpenElement. Acesso em: $25 / 12 / 2013$.

UNITED NATIONS. World Summit Outcome Document. A/RES/60/1. 14 set. 2005. Disponível em: http://www.un.org/womenwatch/ods/A-RES-60-1-E.pdf. Acesso em: 03/09/2014.

UNITED NATIONS. General Assembly. A/62/47. 15 set. 2008. Disponível em: http://daccessdds-ny.un.org/doc/UNDOC/LTD/N07/506/04/PDF/N0750604.pdf?OpenElement. Acesso em: 03/09/2014.

UNITED NATIONS. General Assembly. A/63/960. 23 set. 2008. Disponível em: http://documents-dds-

ny.un.org/doc/UNDOC/GEN/N09/498/42/pdf/N0949842.pdf?OpenElement. Acesso em: 05/09/2014.

UNITED NATIONS. General Assembly. A/63/960. 10 set. 2009. Disponível em: http://documents-dds-

ny.un.org/doc/UNDOC/GEN/N09/498/42/pdf/N0949842.pdf?OpenElement. $\quad$ Acesso em: 05/09/2014.

\section{Artigos de jornais, discursos, declarações e entrevistas:}

Harare Declaration of the Assembly of Heads of State and Government of the Organization of African Unity on the Reform of the United Nations Security Council. 04 jun. 1997. Disponível 
em http://www.globalpolicy.org/component/content/article/200/41390.html Acesso em: $31 / 12 / 2013$.

The Common African Position On The Proposed Reform Of The United Nations: "The Ezulwini Consensus”. 08 mar. 2005. Disponível em: http://www.cfr.org/world/common-african-positionproposed-reform-united-nations-ezulwini-consensus/p25444. Acesso em: 05/01/2014.

CHINA. Position Paper of the People's Republic of China on the United Nations Reforms. 7 jun. 2005. Disponível em: http://www.china-un.org/eng/hyyfy/t199101.htm. Acesso em: 18/02/2014.

CHINA. Position Paper of the People's Republic of China at the 65th Session of the United Nations General Assembly. 14 set. 2010. Disponível em: http://www.chinaun.org/eng/hyyfy/t752396.htm. Acesso em: 18/02/2014.

SILVA, Luiz Inácio Lula. Sessão solene de posse no Congresso Nacional. Brasília. 01 jan. 2003. Disponível em: file://Users/coelhonatalia/Downloads/posse\%20lula\%202003.pdf. Acesso em: 23/08/2014.

Comunicado Conjunto da Presidenta Dilma Rousseff e do Presidente Barack Obama. Brasília. 19 mar. 2011. Disponível em: www.itamaraty.gov.br/salade imprensa/noas-aimprensa/comunicado-conjunto-da-presienta-dilma-rousseff-e-do-presidente-barack-obamabrasília-19-de-marco-de-2011. Acesso em: 03/05/2014.

UK-French Summit: Declaration on Global Governance and Development. 6 jul. 2009. Disponível em: http://www.franceonu.org/france-at-the-united-nations/press-room/speaking-tothe-media/press-releases/article/6-july-2009-uk-french-summit. Acesso em 20/08/2014.

LAMPREIA, Luiz Felipe. A reforma do Conselho de Segurança. Folha de São Paulo. Opinião. 31 ago. 1997. Disponível em: www1.folha.uol.com.br/fsp/1997/8/31/opinião/8.html. Acesso em: 28/08/2014. 
LAMPREIA, Luiz Felipe. "O Brasil e a reforma das Nações Unidas". O Estado de São Paulo. Espaço Aberto. 21 out. 1995. (acesso restrito a assinantes)

DI TELLA, Guido. Menem recua sobre veto ao Brasil na ONU. Folha de São Paulo. Artigo. 20/08/1997. Disponível em: www1.folha.uol.com.br/fsp/brasil/fc200808.htm. Acesso em: 20/08/2014.

LAMPREIA, Luiz Felipe. A reforma do Conselho de Segurança. Folha de São Paulo. Opinião. 31 ago. 1997. Disponível em: wwwl.folha.uol.com.br/fsp/1997/8/31/opinião/8.html. Acesso em: 28/08/2014.

SILVA, Luiz Inácio Lula. Sessão solene de posse no Congresso Nacional. Brasília. 01 jan. 2003. Disponível em: file://Users/coelhonatalia/Downloads/posse\%20lula\%202003.pdf. Acesso em: 23/08/2014.

Rice, Condoleezza. Rethinking the National Interest: American Realism for a New World. Foreign Affairs: July/August, 2008. Disponível em: http://www.foreignaffairs.com/articles/64445/condoleezza-rice/rethinking-the-national-interest. Acesso em: 05/05/2013.

OBAMA, Barack. EUA pedem Índia no Conselho de Segurança. Folha de São Paulo. Mundo. 09 nov. 2010. Disponível em: http://www1.folha.uol.com.br/fsp/mundo/ft0911201002.htm. Acesso em: 02/01/ 2013.

PRIMAKOV, Ievguêni. Folha de São Paulo. Brasil. 26 nov 1997. Disponível em: http://www1.folha.uol.com.br/fsp/1997/11/26/brasil/48.html. Acesso: 21/08/2014. Arraes, 2005: p. 11.

Declaração Conjunta Brasil-Rússia. Brasília. 14 jan. 2002. Disponível em: http://www.itamaraty.gov.br/sala-de-imprensa/notas-a-imprensa/2002/01/14/declaracaoconjunta-brasil-Rússia. Acesso: 21/08/2014. 
JUSTO, Marcelo. BBC Mundo. Rússia entra na OMC e encerra capítulo 'econômico' da Guerra Fria. 22 ago. 2012 Disponível http://www.bbc.co.uk/portuguese/noticias/2012/08/120822_russia_omc_lgb.shtml. Acesso em: 21/08/2014.

LAMPREIA, Luiz Felipe. A reforma do Conselho de Segurança. Folha de São Paulo. Opinião. 31 ago. 1997. Disponível em: www1.folha.uol.com.br/fsp/1997/8/31/opinião/8.html. Acesso em: 30/09/2014.

RODRIGUES, Lorenna. Brasil já é a $7^{\mathrm{a}}$ maior economia do mundo, diz Mantega. Folha de São Paulo. Mercado. 03 mar. 2011. Disponível em: http://www1.folha.uol.com.br/mercado/2011/03/883828-brasil-ja-e-a-7-maior-economia-domundo-diz-mantega.shtml. Acesso em: 25/08/2014.

RITTO, Cecília. Brasil atingiu, em 2010, menor patamar histórico de desigualdade de renda. Veja. Brasil. 03 maio. 2011. Disponível em: http://veja.abril.com.br/noticia/brasil/brasil-atingiuem-2010-menor-patamar-historico-de-desigualdade-de-renda. Acesso em: 25/08/2014.

REDAÇÃO. Brasil Sem Miséria retira 22 milhões da pobreza extrema. Carta Maior. 19 fev. 2013. Disponível em: http://www.cartamaior.com.br/?/Editoria/Politica/Brasil-Sem-Miseriaretira-22-milhoes-da-pobreza-extrema/4/27424. Acesso em: 25/08/2014.

\section{Livros:}

ALAO, Abiodun. Natural resources and conflict in Africa: the tragedy of endowment. Nova York: University of Rochester Press, 2007.

ALMEIDA, Renato. A Liga das Nações: constituição, estrutura e funcionamento. Rio de Janeiro: Sociedade Anônima A noite, 1938. 
AMORIM, Celso. Conversas com jovens diplomatas. São Paulo: Benvirá, 2011.

ANNAN, Kofi. Intervenções: Uma vida de guerra e paz. $1^{\text {a }}$ ed. São Paulo: Companhia das Letras, 2013.

BADEJO, Diedre L. The African Union. New York: Chelsea House Publishers, 2008.

BARACUHY, Braz. Vencer ao perder: A natureza da diplomacia brasileira na Crise da Liga das Nações (1926). Brasília, Funag, 2005.

BARRETO, Fernando de Mello. A política externa após a redemocratização. Tomo I: 19852002. Brasília: FUNAG, 2012a.

BARRETO, Fernando de Mello. A política externa após a redemocratização. Tomo II: 20032010. Brasília: FUNAG, 2012 b.

BAUER, Martin W. \& GASKELL, George. Pesquisa Qualitativa com texto, imagem e som: um manual prático. Petrópolis, RJ, Vozes, 2002.

BELAUNDE, Victor Andres. La Conferencia de San Francisco. Lima: Talleres Graficos de Editorial Lumen S. A., 1945.

BRASIL. Ministério das Relações Exteriores. Secretaria de Planejamento Diplomático. Repertório de política externa: posições do Brasil. Brasília: FUNAG, 2007.

CALÓGERAS, J. Pandiá. Res mostra... O Brasil e a Sociedade das Nações. São Paulo: Irmãos Ferraz, 1930.

CARDOSO, Fernando Henrique. A arte da política: a história que vivi. São Paulo: Civilização Brasileira, 2006. 
CERVO, Amado Luiz; BUENO, Clodoaldo. História da Política Exterior do Brasil. Brasília: Ed. UnB, 4a. ed., 2011.

CERVO, Amado Luiz. Inserção Internacional: formação dos conceitos brasileiros. São Paulo: Ed. Saraiva, 2008.

. O Parlamento brasileiro e as relações exteriores (1826-1889). Brasília: Ed. UnB, 1981.

CERVO, Amado Luiz (org.). O desafio internacional. Brasília: Ed. UnB, 1994.

CORRÊA, Luiz Felipe de Seixas (org.). O Brasil nas Nações Unidas: 1946-2011. Brasília: FUNAG, $3^{\mathrm{a}}$ ed., 2012.

ESCOSTEGUY, Pedro. A nova arquitetura africana de paz e segurança: implicações para o multilateralismo e para as relações do Brasil com a África. Brasília: FUNAG, 2011.

FRANCO, Afonso Arinos de Melo. Um estadista da República: Afrânio de Melo Franco e seu tempo. Rio de Janeiro: Livraria José Olympio Editora, 1955, 3 v.

GARCIA, Eugênio Vargas. Conselho de Segurança das Nações Unidas. Brasília: FUNAG, 2013.

. O sexto membro permanente - O Brasil e a criação da ONU. $1^{\mathrm{a}}$ Ed. Rio de Janeiro: Contraponto, 2012.

. Entre América e Europa: a política externa brasileira na década de 1920. Brasília: Editora UnB e FUNAG, 2006.

. O Brasil e a Liga das Nações (1919-1926): vencer ou não perder. Porto Alegre, Editora da UFRGS, $2^{\mathrm{a}}$ ed, 2005 (Coleção Relações Internacionais e Integração). 
HILDERBRAND, Robert C. Dumbarton Oaks: the origins of the United Nations and the search for postwar security. EUA: The University of North Carolina Press, 1990.

HOBSBAWM, Eric. Era dos extremos: O breve século XX (1914-1991). São Paulo: Companhia das Letras, 1995.

IKENBERRY, G. John. After victory: institutions, strategic restraint, and the rebuilding of order after major wars. Nova Jersey, USA: Princeton University Press, 2001.

JOHNSON, Janet B. \& REYNOLDS, H. T. Political Science Research Methods. Delaware, USA: CQ Press, 6a ed., 2007.

KISSINGER, Henry. Diplomacy. Nova York: Simon \& Schuster Paperbacks, 1994.

LAMPREIA, Luiz Felipe. Diplomacia Brasileira: palavras, contextos e razões. Rio de Janeiro: Lacerda Ed., 1999.

MONTEIRO, Norma de Góes (org.). Ideias políticas de Artur Bernardes. Brasília: Senado Federal, 1984, Vol. I.

PATRIOTA, Antonio de Aguiar. Politica externa brasileira: discursos, artigos, entrevistas (2011-2012). Brasília: FUNAG, 2013.

PIMENTEL, José Vicente de Sá (org.). Pensamento diplomático brasileiro: Formuladores e agentes da política externa (1750-1964). Brasília: FUNAG, 2013, Vol II.

PUREZA, José Manuel. Vuelve la batalla por la reforma de la ONU. In: MESA, Manuela \& BUSTELO, Mabel González (Org). Escenarios de conflicto: Irak y el desorden mundial. Centro de Investigación para la paz. Icaria editorial. Barcelona, 2004. 
RENOUVIN, Pierre \& DUROSELlE, Jean Baptiste. Uma introdução à História das Relações Internacionais. São Paulo: Difel, 1974.

RODRIGUES, Lêda Boechat (org.). Uma História Diplomática do Brasil (1531-1945). Rio de Janeiro: Civilização Brasileira S.A, 1995.

SARAIVA, José Flávio Sombra (org.). História das Relações Internacionais Contemporâneas: da sociedade internacional do século XIX à era da globalização. Brasília: Saraiva, $2^{\mathrm{a}}$ ed., 2008.

SCELLE, Georges. Une crise de la Société des Nations: la réforme du Conseil et l'entrée de l'Allemagne à Genève (mars - septembre 1926). Paris: Les Presses Universitaires de France, 1927.

SOARES, José Carlos de Macedo. O Brasil e a Sociedade das Nações. Paris: A. Pedone Editor, 1927.

VISENTINI, Paulo Fagundes. A projeção internacional do Brasil: 1930-2012. Rio de Janeiro: Elsevier, 2013.

WATSON, Adam. A evolução da sociedade internacional. Ed. UnB: Brasília, 2004.

WEISS, Thomas G. What's wrong with the United Nations and how to fix it. Cambridge, UK: Polite Press, 2009.

\section{Trabalhos não publicados:}

AMORIM, Celso Luiz Nunes. Celso Amorim: depoimento, 1997. Centro de Pesquisa e documentação de História Contemporânea do Brasil (CPDOC), Fundação Getúlio Vargas (FGV). Rio de Janeiro, 2003.

BRAGA, Paula Louane Matos. O governo Bernardes e a Liga das Nações. Dissertação de 
mestrado: Universidade Estadual Paulista. Franca, 2008.

BRIGIDO, Eveline Vieira. O Brasil e a Reforma do Conselho de Segurança da ONU: estratégias da diplomacia brasileira para a obtenção de um assento permanente. Tese de Doutorado: Universidade Federal do Rio Grande do Sul, 2010.

COSTA, Breno de Souza Brasil Dias da. Os Estados Unidos e a reforma do Conselho de Segurança das Nações Unidas: a evolução da posição norte-americana e seus efeitos sobre a candidatura brasileira a membro permanente do CSNU. Instituto Rio Branco, Tese do Curso de Altos Estudos, 2006.

LEUCHARS, Christopher J. R. Brazilian foreign policy and the great powers, 1912-1930. D. Phil Thesis, University of Oxford, 1983.

OLIVEIRA, Glivânia Maria de. A busca de maior democratização das instâncias decisórias internacionais: o G-4 e a elusiva convergência com a África no processo de reforma do CSNU. Brasília: Instituto Rio Branco, LII Curso de Altos Estudos, 2007.

SANTOS, Norma Breda dos. Le Brésil et la Société des Nations, 1920-1926. Tese de doutorado: Université de Genève, Institut Universitaire des Hautes Études Internationales, 1996.

VARGAS, João Augusto Costa. Campanha permanente: A construção do substrato normativo da busca do Brasil por uma reforma do Conselho de Segurança das Nações Unidas. Brasília: UnB, dissertação de mestrado, 2008.

\section{Artigos:}

ALMEIDA, Paulo Roberto de. Never before seeen in Brazil: Luis Inácio Lula da Silva's grand diplomacy. Revista Brasileira de Política Internacional. Vol. 53 (2): 160-177. Brasília, 2010.

. Uma política externa engajada: a diplomacia do governo Lula. Revista Brasileira de 
Política Internacional. Vol. 47 (1): 162-184. Brasília, 2004.

ALVES, Fábio Simão. A dança das cadeiras. JUCA: diplomacia e humanidades. A revista dos alunos do Instituto Rio Branco. Ano 2. Brasília, 2008.

ANDRADE, Letícia Cunha de. O Brasil em busca de um assento permanente no Conselho de Segurança: análise construtivista da Política Externa de 1945 a 2011. Painel: Política Externa Brasileira - Relações Bilaterais e Multilaterais. Brasília, Universidade de Brasília- UnB, 2012. Disponível no site: www.seminariopos2012.abri.org.br. Acesso: 11 outubro 2012.

ARRAES, Virgílio Caixeta. O Brasil e o Conselho de Segurança da Organização das Nações Unidas: dos anos 90 a 2002. Revista Brasileira de Política Internacional. Vol. 48 (2): 152-168. Brasília, 2005.

BARMAN, Roderick. Brazil in the First World War. EUA: History Today, 2014.

CERVO. Conceitos em Relações Internacionais. In: Revista Brasileira de Política Internacional. [online]. 2008, vol.51, n.2

CERVO, Amado Luiz. A política exterior: de Cardoso a Lula. Revista Brasileira de Política Internacional, 46, 7, 2003.

DORATIOTO, Francisco. O Brasil no mundo: idealismos, novos paradigmas e voluntarismo. In: SCHWARCZ, Lilia Moritz (org.). História do Brasil Nação: 1808-2010. Vol. 3. A abertura para o mundo 1889-1930. Fundación MAPFRE. Rio de Janeiro: Objetiva, 2012

FITZGERALD, Amber. Security Council Reform: Creating a More Representative Body of the Entire U.N. Membership. 12 Pace Int'1 L. Rev. 319. EUA, 2000. Disponível em: http://digitalcommons.pace.edu/pilr/vol12/iss2/5. 
FREIESLEBEN, Jonas von. Reform of the Security Council: 1945-2008. In: Governing \& managing change at the United Nations: Security Council Reform from 1945 to September 2013. Nova York: Center for UN Reform Education, 2013.

GARCIA, Eugênio Vargas. De como o Brasil quase se tornou membro permanente do Conselho de Segurança da ONU em 1945. In: Revista Brasileira de Política Internacional. Vol. 54, no. 1. Brasília, 2011.

GONÇALVES, Williams. Panorama da politica externa brasileira no governo Lula da Silva. In: A política externa na Era Lula: um balanço. Rio de Janeiro: Apicuri, 2011.

GOWAN, Richard. Pathways to Security Council Reform. EUA: Center on International Cooperation - New York University, 2014.

HILTON, Stanley. Afrânio de Melo Franco: a consolidação da estratégia de política externa. In: Pensamento Diplomático Brasileiro: Formuladores e agentes da Política Externa (1750-1964). Vol. II. Brasília: FUNAG, 2013 p. 441-486.

HILTON, Stanley. Afrânio de Melo Franco e a diplomacia brasileira, 1917-1943. In: Revista Brasileira de Política Internacional. Rio de Janeiro, v. 29, n. 113/114, 1986, p. 15-46.

LAMPREIA (1997). Discurso de abertura da 52a Sessão Ordinária da Assembléia Geral da ONU, 1997. IN: LAMPREIA, Luiz Felipe. Diplomacia Brasileira: Palavras, contextos e razões. Rio de Janeiro: Lacerda Ed., 1999.

LEUCHARS, Chris. Brazil and the League Council Crisis of 1926. In: Diplomacy and Statecraft. Vol. 12, n. 4. Londres: Frank Cass, 2001 (dezembro), p. 123-142.

LIPJHART, Arend. Comparative Politics and the Comparative Method. American Political Science Review. Vol. 65, p. 682-693, set, 1971. 
MALIK, J. Mohan. Security Council Reform: China Signals Its Veto. World Policy Journal. Vol. 22, No. 1. Califórnia: Sage Publications, 2005

MENEZES, Wagner. Reforma da Organização das Nações Unidas: Perspectivas \& Proposições a Partir do Direito Internacional. In: Reforma da ONU: IV Conferência Nacional de Política Externa e Política Internacional - IV CNPEPI "O Brasil no mundo que vem aí". Brasília: FUNAG, 2010.

PANDA, Jagannath P. Beijing's perspective on UN Security Council Reform: Identity, Activism and Strategy. In: Portuguese Journal of International Affairs (Spring/Summer). Lisboa: Ipris, 2011.

PIROZZI, Nicoletta. RONZITTI, Natalino. The European Union and the Reform of the UN Security Council: Toward a new regionalism? Boston: Istituto Affari Internazionali, 2011. Disponível em: https:/www.globalpolicy.org/images/pdfs/GPFSeminar_FINAL.pdf

SARAIVA, José Flávio Sombra. Autonomia na inserção internacional do Brasil: Um caminho histórico próprio. In: Contexto Internacional, vol. 36, n. 1. Rio de Janeiro: 2014, p. 9-41.

SARAIVA, Miriam Gomes. A América do Sul na política externa do governo Lula: ideias e mudanças. In: A política externa brasileira na Era Lula: um balanço. Rio de Janeiro: Apicuri, 2011.

SARDENBERG, Ronaldo. Reforma das Nações Unidas: impasses, progressos e perspectivas. In: Reforma da ONU: IV Conferência Nacional de Política Externa e Política Internacional - IV CNPEPI "O Brasil no mundo que vem aí". Brasília: FUNAG, 2010.

SILVA, Alexandra de Mello e. Ideias e política externa: a atuação brasileira na Liga das Nações e na ONU. Revista Brasileira de Política Internacional. Ano 41, vol 2. Brasília: 1998, p.139-158. 
SILVA, André Luiz Reis da. Um novo multilateralismo? O discurso do Brasil na Assembléia Geral da ONU durante o Governo Lula (2003-2010). X Encontro Estadual de História. Rio Grande do Sul, 2010.

SILVA, André Luiz Reis da. A Palavra do Brasil na ONU Durante o Governo Fernando Henrique Cardoso (1995-2002): Universo Conceitual. ANPUH - XXV Simpósio Nacional de História. Fortaleza, 2009.

SOARES, João Clemente Baena. Notas sobre a Reforma da ONU e o Brasil. In: LIMA, Maria Regina Soares de. SEMINÁRIO SOBRE A REFORMA DA ONU, FUNAG. Rio de Janeiro, 2009.

- Nossa responsabilidade comum. In: Enfim uma reforma da ONU? Política Externa, Vol. 14 n. 2, Set/Out/Nov. São Paulo: Ed. Paz e Terra, 2005

SWART, Lydia. Reform of Security Council: 2007-2013. In: Governing \& managing change at the United Nations: Security Council Reform from 1945 to September 2013. Nova York: Center for UN Reform Education, 2013.

TARRAGÔ, Piragibe dos Santos. A reforma da ONU: a Comissão de Construção para a Paz e a ampliação do Conselho de Segurança. In: Reforma da ONU: IV Conferência Nacional de Política Externa e Política Internacional - IV CNPEPI "O Brasil no mundo que vem aí". Brasília: FUNAG, 2010.

VAZ, Alcidez. Brazilian foreign policy under Lula: Change or continuity? Dialogue on Globalization, FEX Briefing Paper, 4, 2004.

VIEGAS, Marcelo. A atuação recente do Conselho de Segurança e o Brasil. In: O Brasil e a Organização das Nações Unidas. Brasília: FUNAG, 2008

VIGEVANI, Tullo \& CEPALUNI, Gabriel. (2007). Lula's Foreign Policy and the Quest for 
Autonomy through Diversification. Third World Quarterly, Vol. 28, No. 7, 2007, pgs. 13091326.

VILELA, Elaine \& NEIVA, Pedro. Temas e regiões nas politicas externas de Lula e Fernando Henrique: comparação do discurso dos dois presidentes. Revista Brasileira de Política Internacional. Brasília, Vol. 54, No. 2, 2011, pgs. 70-96.

VIOTTI, Maria Luiza Ribeiro. A Reforma das Nações Unidas. In: Reforma da ONU: IV Conferência Nacional de Política Externa e Política Internacional - IV CNPEPI "O Brasil no mundo que vem aí". Brasília: FUNAG, 2010. 